\section{Publications List}

1) N. Mori, S. Ômura, O. Yamamoto, T. Suzuki, and Y. Tsuzuki: The proton magnetic resonance spectra of some anomeric glycopyranosides. Bull. Chem. Soc. Jpn., 36, 1047-1048 (1963).

2) N. Mori, S. Ômura, O. Yamamoto, T. Suzuki, and Y. Tsuzuki: Intramolecular hydrogen bonding in some aliphatic $\alpha-$ and $\beta$-hydroxy-carboxylates. Bull. Chem. Soc. Jpn., 36, 1401-1407 (1963).

3) M. Kagami and S. Ômura: Effects of refrigeration on various constituents of wines. Bull. Res.Inst. Ferm. Yamanashi Univ., 1-6 (1963).

4) M. Kagami and S. Ômura: Studies on the application of ion exchange process to fermentation industries. XIV. On the stabilization of metallic deterioration of wines. J. Ferm. Technol, 42, 571-575 (1964).

5) K. Sone, M. Kagami, S. Ômura, and M. Takayama: The effects of pectinase on the depth of color of red wine. Bull. Res. Inst. Ferm. Yamanashi Univ., 45-51(1964).

6) N. Mori, S. Ômura, and Y. Tsuzuki: Intramolecular hydrogen bonds. II. On the configuration of isomeric methyl 9,10-dihydroxyoctacecanoates. Bull. Chem. Soc. Jpn., 38, 1037-1038 (1965).

7) N. Mori, S. Ômura, H. Yamakawa, and Y. Tsuzuki: Intramolecular hydrogen bonds. III. Cyanoalkanols. Bull. Chem. Soc. Jpn., 38, 1627-1630 (1965).

8) N. Mori, S. Ômura, and Y. Tsuzuki: Intramolecular hydrogen bonds. IV. Phenylalkane-diols. Bull. Chem. Soc. Jpn., 38, 1631-1634 (1965).

9) N. Mori, S. Ômura, N. Kobayashi, and Y. Tsuzuki: Intramolecular hydrogen bonds. V. Aliphatic hydroxycarboxylates. Bull. Chem. Soc. Jpn., 38, 2149-2155 (1965).

10) N. Mori, S. Ômura, and Y. Tsuzuki: Intramolecular hydrogen bonds. VI. The characteristic infrared $\mathrm{OH}$ spectra of isomeric ethyl $\alpha, \beta$-dihydroxycarboxylates and their geometries. Bull. Chem. Soc. Jpn., 38, 2199-2201(1965).

11) S. Ômura, A. Matsumae, Y. Sano, and T. Hata: Identification of an antibiotic I-1431 isolated from a Streptomyces strain. Kitasato Arch. Exp. Med., 38, 61-75 (1965).

12) S. Ômura, H. Ogura, and T. Hata: Chemistry of leucomycins. I. Partial structure of leucomycin A3 (comm.). Tetrahedron Lett., 1967, 609-613
(1967).

13) S. Ômura, H. Ogura, and T. Hata: Chemistry of leucomycins. II. Structure and stereochemistry of leucomycin A3 (comm.). Tetrahedron Lett., 1967, 1267-1271 (1967).

14) T. Hata, S. Ômura, and A. Matsumae, M. Katagiri, and Y. Sano: Leucomycin A3, a new antibiotic from Streptomyces kitsatoensis. Antimicrob. Agents Chemother. -1966, 631-636 (1967).

15) T. Hata, S. Ômura, M. Katagiri, H. Ogura, K. Naya, J. Abe, and T. Watanabe: Structure of leucomycin A1 (comm.). Chem. Pharm. Bull., 15, 358-359 (1967).

16) S. Ômura, M. Katagiri, and T. Hata: The structure of leucomycins A4, A5, A6, A7, A8, and A9 (comm.). J. Antibiot., 20, 234-235 (1967).

17) Y. Sano, S. Nomura, Y. Kamio, S. Ômura, and T. Hata: Studies on cerulenin. III. Isolation and physico-chemical properties of cerulenin. J. Antibiot., 20, 344-348 (1967).

18) S. Ômura, M. Katagiri, A. Nakagawa, Y. Sano, S. Nomura, and T. Hata: Studies on cerulenin. V. Structure of cerulenin. J. Antibiot., 20, 349-354 (1967).

19) S. Ômura, M. Katagiri, H. Ogura, and T. Hata: Chemistry of leucomycins. I. Partial structure of leucomycin A3. Chem. Pharm. Bull., 15, 1529-1533 (1967).

20) S. Ômura, M. Katagiri, H. Ogura, and T. Hata: Chemistry of leucomycins. II. Glycosidic linkages of mycaminose and mycarose on leucomycin A3. Chem. Pharm. Bull., 16, 1167-1173 (1968).

21) S. Ômura, M. Katagiri, H. Ogura, and T. Hata: Chemistry of leucomycins. III. Structure and stereochemistry of leucomycin A3. Chem. Pharm. Bull., 16, 1181-1186 (1968).

22) S. Ômura, M. Katagiri, and T. Hata: Chemistry of leucomycins. IV. Structure of leucomycin A1. J. Antibiot., 21, 199-203 (1968).

23) S. Ômura, M. Katagiri, and T. Hata: Chemistry of leucomycins. VI. Structure of leucomycin A4, A5, A6, A7, A8 and A9. J. Antibiot., 21, 272- 278 (1968).

24) S. Ômura, M. Katagiri, T. Hata, M. Hiramatsu, T. Kimura, and K. Naya: The allylic rearrangement of the hydroxyl group from C-9 to C-13 and the absolute configuration at C-9 of leucomycin A3. Chem. Pharm. Bull., 16, 1402-1404 (1968).

25) S. Ômura, M. Katagiri, I. Umezawa, K. Komiyama, T. Maekawa, K. Sekikawa, A. Matsumae, and T. Hata: Structure-biological activities relationships among leucomycins and their derivatives. J. Antibiot., 21, 532-538 (1968).

26) M. Onda, Y. Konda, A. Noguchi, S. Ômura, and T. Hata: Revised structure for the naphthalene carboxylic acid from carzinophilin. J. Antibiot., 22, $42-44$ (1969).

27) H. Ogura, T. Itoh, T. Okamoto, and S. Ômura: Nuclear magnetic resonance of semicarbazones and thiosemicarbazones of an aliphatic aldehyde. 
Chem. Pharm. Bull., 17, 844-846 (1969).

28) S. Ômura, A. Nakagawa, M. Otani, T. Hata, H. Ogura, and K. Furuhata: Structure of spiramycins (foromacidines) and their relationships with the leucomycin and carbomycins (magnamycins). J. Am. Chem. Soc., 91, 3401-3404 (1969).

29) S. Ômura, A. Nakagawa, K. Sekikawa, M. Otani, and T. Hata: Studies on cerulenin. VI. Some spectroscopic features of cerulenin. Chem. Pharm. Bull., 17, 2361-2363 (1969).

30) S. Ômura, M. Katagiri, A. Nakagawa, H. Yamada, I. Umezawa, K. Komiyama, and T. Hata: Studies on the chemical structure and some biological properties of leucomycins (kitasamycins) and their related macrolide antibiotics (Review article). In "Progress in Antimicrobial and Anticancer Chemotherapy-Proceedings of the 6th International Congress of Chemotherapy" 1043-1049, University of Tokyo Press (1970).

31) M. Hiramatsu, A. Furusaki, T. Noda, K. Naya, Y. Tomiie, I. Nitta, T. Watanabe, T. Take, J. Abe, S. Ômura and T. Hata: The crystal and molecular structure of demycarosylleucomycin A3 hydro-bromide. Bull. Chem. Soc. Jpn., 43, 1966-1975 (1970).

32) S. Ito, T. Matsuya, S. Ômura, M. Otani, A. Nakagawa, H. Takeshima, Y. Iwai, M. Ohtani, and T. Hata: A new antibiotic, kinamycin. J. Antibiot., 23, 315-317 (1970).

33) S. Ômura, A. Nakagawa, M. Katagiri, T. Hata, M. Hiramatsu, T. Kimura, and K. Naya: Chemistry of leucomycins. VIII. Absolute configuration of leucomycin and isoleucomycin. Chem. Pharm. Bull., 18, 1501-1508 (1970).

34) S. Ômura, Y. Hironaka, and T. Hata: Chemistry of leucomycins. IX. Identification of leucomycin A3 with josamycin. J. Antibiot., 23, 511-513 (1970).

35) S. Ômura: Macrolide antibiotics. (Review article). Kagaku to Seibutsu (Chemistry and Biology), 8, 139-150 (1970).

36) S. Ômura: Studies on macrolide antibiotics (Review article). In "Proceedings of Symposium on Antibiotics of The 14th Annual Meeting of Kanto Branch, Pharmaceutical Soc. Jpn." 13-20 (1970).

37) T. Hata and S. Ômura: Advances in antibiotics. Chemistry and Chemical Industry, 21, 347-354 (1968).

38) S. Ômura, M. Otani, M. Ohtani, and T. Hata: I-2743-C, new antimycin analogue from a Kitasatoa sp. nov. Kitasato Arch. Exp. Med., 43, 29-33 (1970).

39) Y. Iwai, S. Ômura, and T. Hata: Studies on the determination of glycerol in fermented broth of antibiotic-production by Streptomyces sp. J. Ferm. Technol., 49 842-846 (1971).

40) T. Hata, S. Ômura, Y. Iwai, A. Nakagawa, M. Otani, S. Ito, and T. Matsuya: A new antibiotic, kinamycin: Fermentation, isolation, purification and properties. J. Antibiot., 24, 353-359 (1971).

41) M. Onda, Y. Konda, S. Ômura, and T. Hata:
Structure of carzinophilin. II. A new amino acid and its derivative from carzinophilin. Chem. Pharm. Bull., 10, 2013-2019 (1971).

42) Y. Iwai, K. Komiyama, R. Oiwa, J. Awaya, I. Umezawa, S. Ômura, and T. Hata: Studies on anti-L-1210 antibiotic produced by Streptomyces sp., No. OS-1988. Kitasato Arch. Exp. Med., 34, 71-77 (1971).

43) S. Ômura, A. Nakagawa, H. Yamada, T. Hata, A. Furusaki, and T. Watanabe: Structure of kinamycin $\mathrm{C}$, and the structural relationship among kinamycins A, B, C and D (comm.). Chem. Pharm. Bull., 19, 2428-2430 (1971).

44) T. Sato, K. Yamaguchi, M. Katagiri, J. Awaya, Y. Iwai, S. Ômura, and T. Hata: Studies on antibiotic O-2867, a new antibiotic. J. Antibiot., 24, 774-778 (1971).

45) T. Hata, S. Ômura, M. Katagiri, K. Atsumi, and J. Awaya: A new antifungal antibiotic, prumycin. J. Antibiot., 24, 900-901 (1971).

46) T. Hata and S. Ômura: Chemical and biological studies on leucomycins (kitasamycins) (Review article). In "Drug Action and Drug Resistance in Bacteria" (Ed. by S. Mitsuhashi) 267-291, University of Tokyo Press, Tokyo (1971).

47) Y. Iwai, K. Komiyama, R. Oiwa, J. Awaya, I. Umezawa, S. Ômura, and T. Hata: Studies on water-soluble antitumor antibiotics produced by Streptomyces sp., No. OS-786. Kitasato Arch. Exp. Med., 44, 95-105 (1971).

48) S. Nomura, T. Horiuchi, S. Ômura, and T. Hata: The action of mechanism of cerulenin. J. Biochem., 71, 783-796 (1972).

49) S. Koto, S. Zen, S. Ômura, and T. Hata: The synthesis of purine nucleosides of L-mycarose and L-cladinose. Bull. Chem. Soc. Jpn., 45, 532-535 (1972).

50) S. Nomura, T. Horiuchi, T. Hata and S. Ômura: Inhibition of sterol and fatty acid biosyntheses by cerulenin in cell-free systems of yeast. J. Antibiot., 25, 365-368 (1972).

51) D. Vance, I. Goldberg, O. Mitsuhashi, K. Bloch, S. Ômura, and S. Nomura: Inhibition of fatty acid synthetases by the antibiotic cerulenin. Biochem. Biophys. Res. Commun., 48, 649-656 (1972).

52) S. Ômura, M. Tishler, M. Katagiri, and T. Hata: Structure of prumycin, 2,5-diamino-2,5-dideoxypentose containing antibiotic. J. Chem. Soc., Chem. Commun., 1972, 633-634 (1972).

53) S. Ômura, A. Nakagawa, N. Yagisawa, Y. Suzuki, and T. Hata: Chemistry of leucomycins -X. Conformational studies of leucomycin. Tetrahedron, 28, 2839-2848 (1972).

54) S. Ômura, Y. Hironaka, A. Nakagawa, I. Umezawa, and T. Hata: Antimycoplsma activities of macrolide antibiotics. J. Antibiot., 25, 105-108 (1972).

55) S. Koto, K. Yago, S. Zen, S. Ômura, and T. Hata: Synthesis of anomeric methyl 6-O-(L-mycarosyl)- $\beta$-D-glucosaminides. Chem. Lett., 1, 731-732 (1972).

56) A. Furusaki, M. Matsui, T. Watanabe, S. Ômura, A. Nakagawa, and T. Hata: The crystal and 
molecular structure of kinamycin C-p-bromo-benzoate. Israel J. Chem., 10, 173-187 (1972).

57) S. Ômura, M. Tishler, A. Nakagawa, Y. Hironaka, and T. Hata: Relationships of structure and microbiological activities of the 16-membered macrolides. J. Med. Chem., 15, 1011-1015 (1972).

58) S. Koto, K. Yago, S. Zen, and S. Ômura: The synthesis of anomeric methyl 4- $O$-L-mycarosyl- $\beta$-D-mycaminosides. Chem. Lett., 1, 1091-1092 (1972).

59) T. Hata, S. Ômura, Y. Iwai, H. Ohno, H. Takeshima, and N. Yamaguchi: Studies on penicillinase inhibitor produced by microorganisms. J. Antibiot., 25, 473-474 (1972).

60) S. Ômura, A. Nakagawa, H. Yamada, T. Hata, A. Furusaki, and T. Watanabe: Structures and biological properties of kinamycins A, B, C, and D. Chem. Pharm. Bull., 21, 931-940 (1973).

61) Y. Iwai, J. Awaya, T. Kesado, H. Yamada, S. Ômura, and T. Hata: Selective production of cerulenin by Cephalosporium caerulens KF-140. J. Ferm. Technol., 51, 575-581 (1973).

62) H. Ohno, J. Awaya, S. Ômura, S. Sakamoto, and T. Hata: A new proteolytic enzyme having milk clotting activity from Streptomyces sp. No. OS-1000. J. Ferm. Technol., 51, 609-612 (1973).

63) M. Onda, Y. Konda, Y. Narimatsu, S. Ômura, and T. Hata: Structure of pyrindicin. Chem. Pharm. Bull., 21, 2048-2049 (1973).

64) H. Ohno, A. Matsumae, Y. Iwai, M. Nakae, S. Ômura, and T. Hata: In vitro and in vivo activity of penicillinase inhibitor, KA-107 against Staphylococcus aureus FS-1277. Antimicrob. Agents Chemother., 4, 226-230 (1973).

65) Y. Iwai, H. Ohno, H. Takeshima, N. Yamaguchi, S. Ômura, and T. Hata: Screening and isolation of penicillinase inhibitor, KA-107. Antimicrob. Agents Chemother., 4, 222-225 (1973).

66) S. Ômura, M. Katagiri, J. Awaya, K. Atsumi, R. Oiwa, T. Hata, S. Higashikawa, K. Yasui, H. Terada, and S. Kuyama: Production and isolation of a new antifungal antibiotic, prumycin and taxonomic studies of Streptomyces sp., strain No. F-1028. Agricult. Biol. Chem., 37, 2805-2812 (1973).

67) S. Koto, K. Yago, S. Zen, and S. Ômura: Synthesis of anomeric methyl $6-O$-(L-mycarosyl)- $\beta$-D-glucosaminides and 4-O-(L-mycarosyl)- $\beta$-D-mycaminosides. Bull. Chem. Soc. Jpn., 46, 3800-3804 (1973).

68) S. Ômura, Y. Suzuki, A. Nakagawa, and T. Hata: Fast liquid chromatography of macrolide antibiotics. J. Antibiot., 26, 794-796 (1973).

69) G. D'Agnolo, I. S. Rosenfeld, J. Awaya, S. Ômura, and P. R. Vagelos: Inhibition of fatty acid synthesis by the antibiotic cerulenin. Specific inactivation of $\beta$-ketoacyl-acyl carrier protein synthetase. Biochim. Biophys. Acta, 326, 155-166 (1973).

70) S. Ômura and H. Takeshima: Inhibition of the biosynthesis of leucomycin, a macrolide antibiotic, by cerulenin. J. Biochem. 75, 193-195 (1974).

71) B. H. Arison and S. Ômura: Revised structure of cerulenin. J. Antibiot., 27, 28-30 (1974).

72) S. Ômura, A. Nakagawa, K. Suzuki, T. Hata, A. A. Jakubowski, and M. Tishler: Isolation and structure of leuconolide A3 5,18-hemiacetal and 9-dehydro-18-dihydroleucomycin A3. J. Antibiot., 27, 147-149 (1974).

73) T. Ohno, T. Kesado, J. Awaya, and S. Ômura: Target of inhibition by the anti-lipogenic antibiotic cerulenin of sterol synthesis in yeast. Biochem. Biophys. Res. Commun., 57, 1119-1124 (1974).

74) S. Ômura, H. Tanaka, Y. Koyama, R. Oiwa, M. Katagiri, J. Awaya, T. Nagai, and T. Hata: Nanaomycins A and B, new antibiotics produced by a strain of Streptomyces. J. Antibiot., 27, 363-365 (1974).

75) S. Ômura, A. Nakagawa, K. Suzuki, and T. Hata: A new bicyclo lactone from leucomycin A3 by alkali treatment. J. Antibiot., 27, 370-372 (1974).

76) S. Ômura, H. Tanaka, J. Awaya, Y. Narimatsu, Y. Konda, and T. Hata: Pyrindicin, a new alkaloid from a Streptomyces strain. Taxonomy, fermentation, isolation and biological activity. Agricult. Biol. Chem., 38, 899-906 (1974).

77) A. Nakagawa, K. Suzuki, K. Iwasaki, T. Hata and S. Omura: Chemistry of leucomycins. XI. Chemical transformation of a basic macrolide to a neutral macrolide. Chem. Pharm. Bull., 22, 1426-1428 (1974).

78) J. L. Schwartz, M. Katagiri, S. Ômura, and M. Tishler: The mechanism of prumycin action. J. Antibiot., 27, 379-385 (1974).

79) T. Ohno, D. B. P. Goodman, H. Rasmussen, and S. Ômura: A new type of sodium transport inhibitor in the toad bladder. J. Membrane Biol., 18, 295-304 (1974).

80) K. Satoh. K. Komiyama, C. Kitao, Y. Iwai, K. Atsumi, R. Oiwa, M. Katagiri, I. Umezawa, S. Ômura, and T. Hata: Isolation and characterization of a new antitumor antibiotic, OS-3256-B from Streptomyces candidus var. azaticus. J. Antibiot., 27, 620-625 (1974).

81) M. Onda, Y. Konda, Y. Narimatsu, H. Tanaka, J. Awaya, and S. Omura: Alkaloid from Streptomyces sp. NA-337. Chem. Pharm. Bull., 22, 2916-2920 (1974).

82) S. Ômura, M. Katagiri, J. Awaya, T. Furukawa, I. Umezawa, N. Oi, M. Mizoguchi, B. Aoki, and M. Shindo: Relationship between the structures of fatty acid amide derivatives and their antimicrobial activities. Antimicrob. Agents Chemother., 6, 207-215 (1974).

83) S. Ômura, M. Katagiri, K. Atsumi, T. Hata, A. A. Jakubowski, E. B. Springs, and M. Tishler: Structure of prumycin. J. Chem. Soc. Chem. Commun., 1974, 1627-1631 (1974).

84) T. Ohno, J. Awaya, T. Kesado, S. Nomura, and S. Ômura: Mechanism of action of CM-55, a synthetic analogue of the antilipogenic antibiotic cerulenin. Antimicrob. Agents Chemother., 6, 
387-392 (1974).

85) S. Ômura and J. Awaya: Effects of cerulenin on lipid metabolism. Kagaku to Seibutsu, 12, 787-794 (1974).

86) S. Pestka, A. Nakagawa, and S. Ômura: Effect of leucomycins and analogues on binding $\left[{ }^{14} \mathrm{C}\right]$-erythromycin to Escherichia coli ribosomes. Antimicrob. Agents Chemother., 6, 606-612 (1974).

87) K. Atsumi, R. Oiwa, and S. Ômura: Production of bacillin by Bacillus sp. strain No. KM-208 and its identity with tetaine (bacilysin). J. Antibiot. 28, 77-78 (1975).

88) S. Ômura and A. Nakagawa: Chemical and biological studies on 16-membered macrolide antibiotics. J. Antibiot., 28, 401-433 (1975).

89) S. Ômura, Y. Suzuki, C. Kitao, Y. Takahashi, and Y. Konda: Isolation of a new sulfur containing basic substance from a Thermoactinomyces species. J. Antibiot., 28, 609-610 (1975).

90) S. Ômura, A. Nakagawa, A. Neszmelyi, S. D. Gero, A.-M. Sepulchre, F. Piriou, and G. Lukacs: Carbon-13 nuclear magnetic resonance spectral analysis of 16-membered macrolide antibiotics. J. Am. Chem. Soc., 97, 4001-4009 (1975).

91) S. Ômura, N. Neszmelyi, M. Sangara, and G. Lukacs: Conformational homogeneity in solution of 14-membered macrolide antibiotics as evidence by ${ }^{13} \mathrm{C}$ NMR spectroscopy. Tetrahedron Lett., 1975, 2939-2942, (1975).

92) S. Ômura: Advanced studies on 16-membered macrolide antibiotics (Review article). In "Proceedings of the First Intersectional Congress of IAMS" 3, 408-507 (1974).

93) J. Awaya, T. Kesado, and S. Ômura: Preparation of ${ }^{13} \mathrm{C}$ - and ${ }^{3} \mathrm{H}$-labeled cerulenin and biosynthesis with ${ }^{13} \mathrm{C}$ NMR. J. Antibiot., 28, 824-827 (1975).

94) R. Oiwa, M. Katagiri, N. Tanaka, Y. Takahashi, K. Satoh, R. Masuma, and S. Ômura: A new peptide antibiotic KM-8. J. Antibiotics, 28, 819-820 (1975).

95) M. Onda, Y. Konda, Y. Narimatsu, H. Tanaka, J. Awaya, and S. Ômura: Revised structure for an alkaloid from Streptomyces sp. NA-337. Chem. Pharm. Bull., 23, 2462-2463 (1975).

96) H. Tanaka, Y. Koyama, J. Awaya, H. Marumo, R. Oiwa, M. Katagiri, T. Nagai, and S. Ômura: Nanaomycins, new antibiotics produced by a strain of Streptomyces. I. Taxonomy, isolation, characterization and biological properties. J. Antibiot., 28, 860-867 (1975).

97) H. Tanaka, Y. Koyama, T. Nagai, H. Marumo, and S. Ômura: Nanaomycins, new antibiotics produced by a strain of Streptomyces. II. Structure and biosynthesis. J. Antibiot., 28, 868-875 (1975).

98) J. Awaya, T. Ohno, H. Ohno, and S. Ômura: Substitution of cellular fatty acids in yeast cells by the antibiotic cerulenin and exogenous fatty acids. Biochim. Biophys. Acta, 409, 267-273 (1975).

99) S. Ômura, A. Nakagawa, H. Takeshima, J. Miyazawa, and C. Kitao: A ${ }^{13} \mathrm{C}$ nuclear magnetic resonance study of the biosynthesis of the 16-membered macrolide antibiotic tylosin. Tetrahedron Lett., 1975, 4503-4506 (1975).

100) H. Tanaka, H. Marumo, T. Nagai, M. Okada, K. Taniguchi, and S. Ômura: Nanaomycins, new antibiotics produced by a strain of Streptomyces. III. A new component, nanaomycin $\mathrm{C}$, and biological activities of nanaomycin derivatives. J. Antibiotics, 28, 925-930 (1975).

101) S. Ômura, A. Nakagawa, H. Takeshima, K. Atsumi, J. Miyazawa, F. Piriou, and G. Lukacs: Biosynthetic studies using ${ }^{13} \mathrm{C}$ enriched precursors on the 16-membered macrolide antibiotic leucomycin A3. J. Am. Chem. Soc., 97, 6600-6602 (1975).

102) H. Ohno, T. Ohno, J. Awaya, and S. Ômura: Inhibition of 6-methylsalicylic acid synthesis by the antibiotic cerulenin. J. Biochem., 78, 1149-1152 (1975).

103) A. Neszmelyi, S. Ômura, and G. Lukacs: Carbon-13 spin-lattice relaxation times and their use for spectral analysis of 16-membered macrolide antibiotics. J. Chem. Soc., Chem. Commun., 1976, 97-98, (1976)

104) Y. Konda, Y. Suzuki, S. Ômura, and M. Onda: Alkaloid from Thermoactinomyces species. Chem. Pharm. Bull., 24, 92-96 (1976).

105) T. Ohno, J. Awaya, and S. Ômura: Inhibition of sporulation by cerulenin and its reversion by exogenous fatty acids in Saccharomyces cerevisiae. Antimicrob. Agents Chemother., 9, 42-48 (1976).

106) J. L. Schwartz, M. Tishler, B. H. Arison, H. M. Safer, and S. Ômura: Identification of mycolutein and pulvomycin as aureothin and labilomycin, respectively. J. Antibiot., 29, 236-241 (1976).

107) S. Ômura, H. Takeshima, A. Nakagawa, and J. Miyazawa: The biosynthesis of picromycin using ${ }^{13} \mathrm{C}$ enriched precursors. J. Antibiot., 29, 316-317 (1976).

108) S. Ômura, T. Nishikiori, R. Oiwa, Y. Iwai, R. Masuma, and M. Katagiri: A new antibiotic KM-214 produced by a strain of Bacillus. J. Antibiot., 29, 477-478 (1976).

109) S. Ômura, H. Tanaka, Y. Okada, and H. Marumo: Isolation and structure of nanaomycin $\mathrm{D}$, an enantiomer of the antibiotic kalafungin. J. Chem. Soc., Chem. Commun., 1976, 320-321 (1976).

110) S. Ômura, Y. Iwai, Y. Suzuki, J. Awaya, Y. Konda, and M. Onda: Production of quinoline-2-methanol and quinoline-2-methanol acetate by a new species of Kitasatoa, Kitasatoa griseophaeus. J. Antibiot., 29, 797-803 (1976).

111) A. Nakagawa, K. Suzuki, K. Iwasaki, K. Kaji, S. Ômura, A. Jakubowski, and M. Tishler: Chemistry of leucomycins. XII. Application of the modified Polonovski reaction to leucomycin A3 $N$-oxide. Chem. Pharm. Bull., 24, 1749-1756 (1976).

112) S. Ômura, C. Kitao, H. Tanaka, R. Oiwa, Y. Takahashi, A. Nakagawa, M. Shimada, and Y. Iwai: A new antibiotic, asukamycin, produced by Streptomyces. J. Antibiot., 29, 876-881 
(1976).

113) K. Ajisaka, H. Takeshima, and S. Ômura: Application in biosynthetic studies of ${ }^{13} \mathrm{C}$ isotope shifts in infrared spectroscopy. J. Chem. Soc., Chem. Commun., 1976, 571-572 (1976).

114) T. Miyazaki, H. Yamada, J. Awaya, and S. Omura: Isolation and structure of an extracellular polysaccharide from Streptomyces sp. FERM-P1185. J. Gen. Microbiol., 95, 31-38 (1976).

115) S. Ômura, J. Miyazawa, H. Takeshima, C. Kitao, K. Atsumi, and M. Aizawa: Bioconversion of leucomycins and its regulation by butyrate in a producing strain. J. Antibiot., 29, 1131-1133 (1976).

116) I. Umezawa, K. Komiyama, H. Takeshima, J. Awaya, and S. Omura: A new antitumor antibiotic, PO-357. J. Antibiot., 29, 1249-1251 (1976).

117) T. Hata, S. Nomura, T. Horiuchi, and S. Ômura: Mode of action of cerulenin on Candida and Saccharomyces. (Review article). In "Proceedings of the Second International Specialized Symposium on Yeast, Tokyo" (Ed. by K. Iwata) 323-332, University of Tokyo Press (1972).

118) S. Ômura, H. Tanaka, M. Shinohara, R. Oiwa, and T. Hata: Inhibition of bacterial cell wall synthesis by amphomycin (Review article). In "Chemotherapy" (Eds. by J. D. Williams and A. M. Geddes) 5, 365-360, Plenum Publishing Co. (1976).

119) S. Ômura: The antibiotic cerulenin, a novel tool for biochemistry as an inhibitor of fatty acid synthesis. Bacteriol. Rev., 40, 681-697 (1976).

120) S. Ômura, H. Imai, H. Takeshima, and A. Nakagawa: Structure of a new antimicrobial unsaturated fatty acid from Sm. kitasatoensis NU-23-1. Chem. Pharm. Bull., 24, 3139-3143 (1976).

121) A. Ducruix, C. Pascard, A. Nakagawa, and S. Ômura: Crystal and molecular structure of diacetyl-3,6-bicyclo-leuconolide A3. J. Chem. Soc., Chem. Commun., 1976, 947-948 (1976).

122) S. Ômura, J. Miyazawa, H. Takeshima, and C. Kitao: Induction of the bioconversion of leucomycins by glucose in a producing strain. J. Antibiot., 30, 192-193 (1977).

123) S. Ômura, H. Takeshima, A. Nakagawa, N. Kanemoto, and G. Lukacs: Studies on carboxylic acid metabolism in a macrolide-producing microorganisms using carbon-13 magnetic resonance. Bioorg. Chem., 5, 451-454 (1976).

124) A. Neszmelyi, S. Ômura, T. T. Thang, and G. Lukacs: A carbon-13 spin-lattice relaxation time study of 14-membered macrolide antibiotics. Tetrahedron Lett., 1977, 725-728 (1977).

125) S. Ômura: Cerulenin. (Review article) Pharmacia, 13, 109-112 (1977).

126) M. Shimada, H. Honda, J. Awaya, and S. Ômura: A new antibiotic, OS-1804. J. Antibiot., 30, 330-331 (1977).

127) S. Ômura, Y. Iwai, A. Hirano, A. Nakagawa, J.
Awaya, H. Tsuchiya, Y. Takahashi, and R. Masuma: A new alkaloid AM-2282 of Streptomyces origin. Fermentation, isolation and preliminary characterization. J. Antibiot., 30, 275-282 (1977).

128) S. Ômura, A. Nakagawa, M. Machida, and H. Imai: Evidence for configurational identity between leucomycin and tylosin. Tetrahedron Lett., 1977, 1045-1048 (1977).

129) H. Takeshima, C. Kitao, and S. Ômura: Inhibition of the biosynthesis of leucomycin, a macrolide antibiotic, by cerulenin. J. Biochem., 81, 1127-1132 (1977).

130) H. Tanaka, Y. Iwai, R. Oiwa, S. Shinohara, S. Shimizu, T. Oka, and S. Ômura: Studies on bacterial cell wall inhibitors. II. Inhibition of peptidoglycan synthesis in vivo and in vitro by amphomycin. Biochim. Biophys. Acta, 497, 633-640 (1977).

131) Y. Iwai, H. Tanaka, R. Oiwa, S. Shimizu and S. Ômura: Studies on bacterial cell wall inhibitors. III. 3-Amino-3-deoxy-D-glucose, an inhibitor of bacterial cell wall synthesis. Biochim. Biophys. Acta, 498, 223-228 (1977).

132) S. Ômura, A. Nakagawa, H. Sakakibara, O. Okekawa, R. Brandsch, and S. Pestka: Structure-activity relationships among the $O$-acyl derivatives of leucomycin. Correlation of minimal inhibitory concentrations with binding to Escherichia coli ribosomes. J. Med. Chem., 20, 732-736 (1977).

133) S. Ômura, H. Takeshima, A. Nakagawa, J. Miyazawa, F. Piriou, and G. Lukacs: Studies on the biosynthesis of 16-membered macrolide antibiotics using carbon-13 nuclear magnetic resonance spectroscopy. Biochemistry, 16, 2860-2866 (1977).

134) S. Ômura and H. Takeshima: Studies on the biosynthesis of macrolide antibiotics (Review article). Kagaku to Seibutsu, 15, 309-453 (1977).

135) S. Ômura, Y. Iwai, A. Hirano, J. Awaya, Y. Suzuki, and K. Matsumoto: A new antibiotic, AM-2504. Agricult. Biol. Chem., 41, 1827-1828 (1977).

136) A. Ducruix, C. Pascard, S. Ômura and A. Nakagawa:

5,9-Diacetyl(3,6)-bicycloleuconolide A3. Acta Cryst. B33, 2314-2316 (1977).

137) M. D. Greenspan, R. C. Macknow, and S Ômura: The effect of cerulenin on sterol biosynthesis in Saccharomyces.. Lipids, 12, 729-731 (1977).

138) S. Ômura, H. Tanaka, R. Oiwa, J. Awaya, R. Masuma, and K. Tanaka: New antitumor antibiotics, OS-4742 A1, A2, B1 and B2 produced by a strain of Streptomyces. J. Antibiot., 30, 908-916 (1977).

139) T. T. Thang, G. Lukacs, S. Ômura, P. Bartner, D. L. Boxler, R. Brambilla, A. K. Mallams, J. B. Morton, P. Reichert, F. D. Sancilio. H. Surprenant, and G. Tomalesky: Megalomicins. 6. Tertiary glycosidic macrolide antibiotics. A structural revision by carbon-13 nuclear magnetic resonance and X-ray crystallography. J. Am. Chem. Soc., 100, 663-666 (1978). 
140) Y. Iwai, K. Kumano, and S. Ômura: Biosynthetic studies of microbial alkaloid pyrindicin using C-13 labelled precursors. Chem. Pharm. Bull., 26, 736-739 (1978).

141) S. Ômura, C. Kitao, J. Miyazawa, H. Imai, and H. Takeshima: Bioconversion and biosynthesis of 16-membered macrolide antibiotic, tylosin, using enzyme inhibitor: cerulenin. J. Antibiot., 31, 254-256 (1978).

142) Y. Iwai, A. Hirano, J. Awaya, S. Matsuo, and S. Ômura: 1,3-Diphenethylurea from Streptomyces sp. No. AM-2948. J. Antibiot., 31, 375-376 (1978).

143) T. Nishikiori, R. Masuma, R. Oiwa, M. Katagiri, J. Awaya, Y. Iwai, and S. Ômura: Aurantinin, a new antibiotic of bacterial origin. J. Antibiot., 31, 525-532 (1978).

144) S. Ômura, H. Ohno, T. Saheki, M. Yoshida, and A. Nakagawa: Elasnin, a new human granulocyte elastase inhibitor produced by a strain of Streptomyces. Biochem. Biophys. Res. Commun., 83, 704-709 (1978).

145) Y. Iwai, A. Kora, Y. Takahashi, T. Hayashi, J. Awaya, R. Masuma, R. Oiwa, and S. Ômura: Production of deoxyfrenolicin and a new antibiotic, frenolicin by Streptomyces roseofulvus strain AM-3867. J. Antibiot., 31, 959-965 (1978).

146) S. Ômura, H. Tanaka, Y. Iwai, K. Nishigaki, J. Awaya, Y. Takahashi, and R. Masuma: A new antibiotic, setomimycin, produced by a strain of Streptomyces. J. Antibiot., 31, 1091-1098 (1978).

147) H. Ohno, T. Saheki, J. Awaya, A. Nakagawa, and S. Ômura: Isolation and characterization of elasnin, a new human granulocyte elastase inhibitor produced by a strain of Streptomyces. J. Antibiot., 31, 1116-1123 (1978).

148) A Furusaki, N. Hashiba, T. Matsumoto, A. Hirano, Y. Iwai, and S. Ômura: X-ray crystal structure of staurosporine: a new alkaloid from Streptomyces strain. J. Chem. Soc. Chem. Commun., 1978, 800-801 (1978).

149) S. Ômura, C, Kitao, H. Hamada, and H. Ikeda: Bioconversion and biosynthesis of 16-membered macrolide antibiotics. X. Final steps in the biosynthesis of spiramycin, using enzyme inhibitor: cerulenin. Chem. Pharm. Bull., 27, 176-182 (1979).

150) S. Ômura and J. Awaya: Lipid metabolism and antibiotic cerulenin, inhibitor of fatty acid synthesis. (Review article). Yakugaku, 28, 75-80 (1979).

151) H. Tanaka, R. Oiwa, S. Matsukura, and S. Ômura: Amphomycin inhibits phospho- $N$-acetylmuramyl-pentapeptide translocase in peptidoglycan synthesis of Bacillus. Biochem. Biophys. Res. Commun., 86, 902-908 (1979).

152) S. Ômura and Y. Iwai: Microbial alkaloid (Review article). Hakko to Kogyo, 37, 223-234 (1979).

153) S. Ômura, Y. Iwai, Y. Takahashi, N. Sadakane, A. Nakagawa, H. Oiwa, Y. Hasegawa, and T. Ikai: Herbimycin, a new antibiotic produced by a strain of Streptomyces. J. Antibiot., 32, 255-261 (1979).

154) S. Okubo, N. Nakamura, K. Ito, H. Marumo, M. Tanaka, and S. Ômura: Antitumor activity of prumycin. J. Antibiot., 32, 347-354 (1979).

155) R. W. Burg, B. M. Miller, E. E. Baker, J. Birnbaum, S. A. Currie, R. Hartman, Y. -L. Kong, R. Monaghan, G. Olson, I. Putter, J. B. Tunac, H. Wallick, E. O. Stapley, R. Oiwa, and S. Ômura: Avermectins, new family of potent anthelmintic agents: producing organism and fermentation. Antimicrob. Agents Chemother., 15, 361-367 (1979).

156) C. Kitao, J. Miyazawa, and S. Ômura: Induction of the bioconversion of leucomycins by glucose and its regulation by butyrate. Agricult. Biol.Chem., 43, 833-839 (1979).

157) M. Kasai, K. Shirahata, S. Ishi, K. Mineura, H. Marumo, H. Tanaka, and S. Ômura: Structure of nanaomycin E, a new nanaomycin. J. Antibiot., 32, 442-445 (1979).

158) C. Kitao, H. Ikeda, H. Hamada, and S. Ômura: Bioconversion and biosynthesis of 16-membered macrolide antibiotics. XIII. Regulation of spiramycin I 3-hydroxyl acylase formation by glucose, butyrate, and cerulenin. J. Antibiot., 32, 593-599 (1979).

159) H. Tanaka, S. Shimizu, R. Oiwa, Y. Iwai, and S. Ômura: The site of inhibition of cell wall synthesis by 3-amino-3-deoxy-D-glucose in Staphylococcus aureus. J. Biochem., 86 155-159 (1979).

160) K. Kakinuma, N. Ikekawa, A. Nakagawa, and S. Ômura: The structure of asukamycin, a possible shunt metabolite from 3-dehydroquinic acid in the shikimate pathway. J. Am. Chem. Soc., 101, 3402-3404 (1979).

161) S. Ômura, A. Nakagawa, and H. Ohno: Structure of elasnin, a novel elastase inhibitor. J. Am. Chem. Soc., 101, 4386-4388 (1979).

162) S. Ômura and C. Kitao: Biosynthesis of macrolide antibiotics (Review article). Hakko to Kogyo, 37, 749-764 (1979).

163) A. Hirano, Y. Iwai, R. Masuma, K. Tei, and S. Ômura: Neoxaline, a new alkaloid produced by Aspergillus japonicus. Production, isolation and properties. J. Antibiot., 32, 781-785 (1979).

164) S. Ômura, A. Hirano, Y. Iwai, and R. Masuma: Herquline, a new alkaloid produced by Penicillium herquei. Fermentation, isolation and properties. J. Antibiot., 32, 786-790 (1979).

165) P. Bartner, D. L. Boxler, R. Brambilla, A. K. Mallams, J. B. Morton, P. Reichert, F. D. Sancilio, H. Surprenant, G. Tomalesky, G. Lukacs, A. Olesker, T. T. Thang, L. Valente, and S. Ômura: The megalomicins. Part 7. A structural revision by carbon-13 nuclear magnetic resonance and X-ray crystallography. Synthesis and conformational analysis of 3-dimethylamino- and 3-azido-D- and -L-hexopyranosides, and the crystal structure of 4"-O-(4-iodobenzoyl)megalomicin A. J. Chem. Soc. Perkin I, 1979, 1600-1624 (1979).

166) S. Ômura, A. Nakagawa, and N. Sadakane: 
Structure of herbimycin, a new ansamycin antibiotic. Tetrahedron Lett., 1979, 4323-4326 (1979).

167) S. Ômura, H. Tanaka, R. Oiwa, T. Nagai, Y. Koyama, and Y. Takahashi: Studies on bacterial cell wall inhibitors. VI. Screening method for the specific inhibitors of peptidoglycan synthesis. J. Antibiot., 32, 978-984 (1979).

168) S. Ômura, H. Tanaka, Y. Tanaka, P. Spiri-Nakagawa, R. Oiwa, Y. Takahashi, K. Matsuyama, and Y. Iwai: Studies on bacterial cell wall inhibitors. VII. Azureomycins A and B, new antibiotics produced by Pseudonocardia azurea nov. sp. Taxonomy of the producing organism, isolation, characterization and biological properties. J. Antibiot., 32, 985-994 (1979).

169) P. Spiri-Nakagawa, Y. Tanaka, R. Oiwa, H. Tanaka, and S. Ômura: Studies on bacterial cell wall inhibitors. VIII. Mode of action of a new antibiotic, azureomycin B in Bacillus cereus T. J. Antibiot., 32, 995-1001 (1979).

170) J. Awaya, K. Matsuyama, Y. Iwai, and S. Ômura: Production of $9-\beta$-D-arabinofuranosyl-adenine by a new species of Streptomyces and its herbicidal activity. J. Antibiot., 32, 1050-1054 (1979).

171) C. Kitao, H. Hamada, H. Ikeda, and S. Ômura: Bioconversion and biosynthesis of 16-membered macrolide antibiotics. XV. Final steps in the biosynthesis of leucomycins. J. Antibiot., 32, 1055-1057 (1979).

172) S. Ômura, H. Ikeda, and C. Kitao: The detection of a plasmid in Streptomyces ambofaciens. KA-1028 and its possible involvement in spiramycin production. $J$. Antibiot., 32, 1058-1060 (1979).

173) A. Kawaguchi, H. Tomoda, S. Okuda, J. Awaya, and S. Ômura: Cerulenin resistance in a cerulenin-producing fungus. Isolation of cerulenin insensitive fatty acid synthetase. Arch. Biochem. Biophys., 197, 30-35 (1979).

174) S. Ômura, H. Ikeda, and C. Kitao: Isolation and properties of spiramycin I 3-hydroxyl acylase from Streptomyces ambofaciens. J. Biochem., 86, 1753-1758 (1979).

175) S. Ômura and H. Sakakibara: Chemical modification of 16-membered macrolide antibiotics (Review article). Hakko to Kogyo 37, 1171-1186 (1979).

176) Y. Iwai, A. Nakagawa, A. Nagai, K. Matsuyama, Y. Takahashi, M. Yamashita, A. Hirano, and S. Ômura: 2'-Amino-2'-deoxyadenosine produced by a strain of Actinomadura. J. Antibiot., 32, 1367-1369 (1979).

177) S. Okubo, N. Nakamura, M. Morimoto, K. Mineura, H. Marumo, and S. Ômura: Studies on antitumor activity of prumycin. II. Studies on distribution and excretion of prumycin. $\mathrm{J}$. Antibiot., 33, 221-225 (1980).

178) S. Okubo, N. Nakamura, M. Morimoto, K. Mineura, H. Marumo, and S. Ômura: Studies on antitumor activity of prumycin. III. Mode of action of prumycin on HeLa S-3 cells. J. Antibiot., 33, 226-230 (1980).
179) S. Okubo, M. Morimoto, K. Mineura, H. Marumo, and S. Ômura: Studies on antitumor activity of prumycin. IV. Effect of prumycin on mouse immune system. J. Antibiot., 33, 231-235 (1980).

180) S. Ômura and H. Sakakibara: Chemical modification of 14-membered macrolide antibiotics (Review article). Yuki Gosei Kagaku, 38, 395-414 (1980).

181) H. Ohno, M. Yoshida, Y. Takahashi, and S. Ômura: Improvement of the productivity of elasnin, a specific elastase inhibitor, by Streptomyces noboritoensis KM-2753. J. Antibiot., 33, 474-479 (1980).

182) S. Ômura: Searching for new antibiotics (Review article). Pharmacia, 16, 385-398 (1980).

183) S. Ômura, C. Kitao, and H. Matsubara: Isolation and characterization of a new 16-membered lactone, protylonolide, from a mutant of tylosin-producing strain, Streptomyces fradiae KA-427. Chem. Pharm. Bull., 29, 1963-1965 (1980).

184) C. Kitao, H. Tanaka, S. Minami, and S. Ômura: Bioconversion and biosynthesis of nanaomycins using cerulenin, a specific inhibitor of fatty acid and polyketide biosyntheses. J. Antibiot., 33, 711-716 (1980).

185) S. Ômura, Y. Iwai, R. Masuma, M. Hayashi, T. Furusato, and T. Takagaki: A new peptide antibiotics, alboleutin. J. Antibiot., 33, 758-759 (1980).

186) A. Furusaki, T. Matsumoto, A. Nakagawa, and S. Ômura: Herbimycin A: an ansamycin antibiotic; X-ray crystal structure. J. Antibiot., 33, 781-782 (1980).

187) P. Spiri-Nakagawa, R. Oiwa, Y. Tanaka, H. Tanaka, and S. Ômura: The site of inhibition of bacterial cell wall peptidoglycan synthesis by azureomycin B, a new antibiotic. J. Biochem., 88, 565-570 (1980).

188) S. Ômura, C. Kitao, and N. Sadakane: The microbial transformation of tylosin by the spiramycin-producing strain, Streptomyces ambofaciens KA-1028. J. Antibiot., 33, 911-912 (1980).

189) S. Ômura, N. Sadakane, C. Kitao, H. Matsubara, and A. Nakagawa: Production of mycarosyl protylonolide by a mycaminose idiotroph from the tylosin-producing strain Streptomyces fradiae KA-427. J. Antibiot., 33, 913-914 (1980).

190) S. Ômura, H. Matsubara, A. Nakagawa, A. Furusaki, and T. Matsumoto: X-ray crystallography of protylonolide and absolute configuration of tylosin. J. Antibiot., 33, 915-917 (1980).

191) A. Nakagawa, H. Ohno, K. Miyano, and S. Ômura: Structure of elasnin, a novel elastase inhibitor containing an $\alpha$-pyrone ring. J. Org. Chem., 45, 3268-3274 (1980).

192) A. Furusaki, T. Matsumoto, H. Ogura, H. Takayanagi, A. Hirano, and S. Ômura: X-ray crystal structure of herquline, a new biologically active piperazine from Penicillium herquei 
Fg-372. J. Chem. Soc., Chem. Commun., 1980, 698 (1980).

193) Y. Iwai, A. Nakagawa, N. Sadakane, S. Ômura, H. Oiwa, S. Matsumoto, M. Takahashi, T. Ikai, and Y. Ochiai: Herbimycin B, a new benzo-quinonoid ansamycin with anti-TMV and herbicidal activities. J. Antibiot., 33, 1114-1119 (1980).

194) Y. Konda, M. Onda, A. Hirano, and S. Ômura: Oxaline and neoxaline. Chem. Pharm. Bull., 28, 2987-2993 (1980).

195) S. Ômura, A. Nakagawa, H. Hashimoto, R. Oiwa, Y. Iwai, A. Hirano, N. Shibukawa, and Y. Kojima: Virantmycin, a potent antiviral antibiotic produced by a strain of Streptomyces. J. Antibiot., 33, 1395-1396 (1980).

196) H. Marumo, K. Kitaura, M. Morimoto, H. Tanaka, and S. Ômura: The mode of action of nanaomycin A in Gram-positive bacteria. J. Antibiot., 33, 885-890 (1980).

197) K. Kitaura, Y. Araki, H. Marumo, and S. Ômura: The therapeutic effect of nanaomycin A against experimental Trichophyton mentagrophytes infection in guinea pigs. Jpn. J. Antibiot., 33, 728-732 (1980).

198) S. Ômura: Biosynthetic precursors of natural products (5)--Antibiotics (Review article). Kagaku no Ryoiki, 34, 18-27 (1980).

199) S. Ômura, Y. Tanaka, C. Kitao, H. Tanaka, and Y. Iwai: Stimulation of leucomycin production by magnesium phosphate and its relevance to nitrogen catabolite regulation. Antimicrob. Agents Chemother., 18, 691-695 (1980).

200) S. Ômura, Y. Tanaka, H. Tanaka, Y. Takahashi, and Y. Iwai: Stimulation of the production of macrolide antibiotics by magnesium phosphate and related insoluble materials. J. Antibiot., 33, 1568-1569 (1980).

201) S. Ômura, H. Ikeda, H. Matsubara, and N. Sadakane: Hybrid biosynthesis and absolute configuration of macrolide antibiotic M-4365G1. J. Antibiot., 33, 1570-1572 (1980).

202) K. Kakinuma, N. Imamura, N. Ikekawa, H. Tanaka, S. Minami, and S. Ômura: Structure and biosynthesis of setomimycin. A novel 9,9'-bianthryl antibiotic. J. Am. Chem. Soc., 102, 7493-7498 (1980).

203) K. Otoguro, J. Awaya, H. Tanaka, and S. Ômura: Saturated fatty acid-starved cells of Saccharomyces cerevisiae grown in the presence of cerulenin and oleic acid. J. Biochem., 89, 523-529 (1981)

204) F. Taguchi, Y. Imatani, D. Nagaki, A. Nakagawa, and S. Ômura: Selective antiviral activity of the antibiotic 2'-amino-2'-deoxyribofuranosyl adenine. J. Antibiot., 34, 313-316 (1981).

205) S. Ômura: Macrolide antibiotics (Review article). In "Antibiotics" (Ed. by H. Yonehara) 187-223, Chikyu-sha (1981).

206) S. Omura and A. Nakagawa: Biosynthesis of 16-membered macrolide antibiotics (Review article). In "Antibiotics IV, Biosynthesis" (Ed. by J. W. Corcoran) 175-192, Springer-Verlag (1981).
207) A. Nakagawa, N. Sadakane and S. Ômura: Structure of herbimycin B. J. Chem. Soc. Jpn., Chem. \& Ind. Chem., 1981, 892-894 (1981).

208) S. Ômura, H. Ikeda, and H. Tanaka: Extraction and characterization of plasmids from macrolide antibiotic-producing streptomycetes. Antibiot., 34, 478-482 (1981).

209) S. Ômura and A. Nakagawa: Structure of virantmycin, a novel antiviral antibiotic. Tetrahedron Lett., 22, 2199-2202 (1981).

210) N. Imamura, K. Kakinuma, N. Ikekawa, H. Tanaka, and S. Ômura: Identification of the aglycon part of vineomycin A1 with aquayamycin. Chem. Pharm. Bull., 29. 1788-1790 (1981).

211) S. Ômura, S. Minami, and H. Tanaka: Biosynthesis of nanaomycin: Syntheses of nanaomycin $\mathrm{E}$ from nanaomycin $\mathrm{A}$ and of nanaomycin B from nanaomycin $\mathrm{E}$ in a cell-free system. J. Biochem., 90, 291-293 (1981).

212) S. Ômura, H. Tanaka, S. Minami, and I. Takahashi: Biosynthesis of nanaomycin. II. Purification and properties of nanaomycin D reductase involved in the formation of nanaomycin A from nanaomycin D. J. Biochem. ,90, 355-362 (1981).

213) H. Sakakibara, O. Okekawa, T. Fujiwara, M. Otani, and S. Ômura: Acyl derivatives of 16-membered macrolides. I. Synthesis and biological properties of 3"-O-propionyl-leucomycin A5 (TMS19-Q). J. Antibiot., 34,, 1001-1010 (1981).

214) H. Sakakibara, O. Okekawa, T. Fujiwara, M. Aizawa, and S. Ômura: Acyl derivatives of 16-membered macrolides. II. Antibacterial activities and serum levels of $3 "-O$-acyl derivatives of leucomycin. J. Antibiot., 34, 1011-1018 (1981).

215) Y. Konda, M. Onda, K. Hinotozawa, and S. Omura: Structure of antitumor alkaloid AM6201. J. Antibiot., 34, 1222-1223 (1981).

216) S. Ômura, K. Otoguro, T. Nishikiori, R. Oiwa, and Y. Iwai: Setamycin, a new antibiotic. J. Antibiot., 34, 1253-1256 (1981).

217) S. Ômura: Screening of specific inhibitors of cell wall peptidoglycan synthesis (Review article): An approach to early identification of new antibiotics. In "The Future of Antibiotherapy and Antibiotic Research" (Eds. by L. Ninet, P. E. Bost, D. H. Bouanchaud, and J. Florent) 389-405, Academic Press (1981).

218) A. Nakagawa, Y. Iwai, H. Hashimoto, N. Miyazaki, R. Oiwa, Y. Takahashi, A. Hirano, N. Shibukawa, Y. Kojima, and S. Ômura: Virantmycin, a new antiviral antibiotic produced by a strain of Streptomyces. J. Antibiot., 34, 1408-1415 (1981).

219) S. Ômura: Cerulenin (Review article). In "Methods in Enzymology" (Ed. by J. M. Lowenstein) 72, 520-532, Academic Press (1981).

220) N. Imamura, K. Kakinuma, N. Ikekawa, H. Tanaka, and S. Ômura: The structure of vineomycin B2. J. Antibiot., 34,1517-1518 (1981). 
221) Y. Tanaka, Y. Takahashi, R. Masuma, Y. Iwai, H. Tanaka, and S. Ômura: Enhancement and cultural characteristics of leucomycin production by Streptomyces kitasatoensis in the presence of magnesium phosphate. Agricult. Biol. Chem., 45, 2475-2481 (1981).

222) Y. Tanaka, S. Ômura, K. Araki, and K. Nakayama: Derepression of glycine decarboxylase synthesis by magnesium phosphate in Nocardia butanica. Agricult. Biol. Chem., 45, 2661-2664 (1981).

223) H. Sakakibara, T. Fujiwara, M. Aizawa, and S. Ômura: 9-epi-Leucomycin $\mathrm{A}_{5}$. Synthesis and antimicrobial activity. J. Antibiot., 34, 1577-1580 (1981).

224) S. Ômura, Y. Iwai, Y. Takahashi, K. Kojima, K. Otoguro, and R. Oiwa: Type of diaminopimelic acid different in aerial and vegetative mycelia of setamycin-producing actinomycete KM-6054. J. Antibiot., 34, 1633-1634 (1981).

225) Y. Tanaka, H. Tanaka, S. Ômura, K. Araki, and K. Nakayama: Magnesium phosphates stimulate microbial conversion of glycine to L-serine by release from regulation by ammonium ions. J. Ferment. Technol., 59, 447-455 (1981).

226) S. Ômura and R. Oiwa: Avermectin (Review article). Kagaku to Seibutsu, 20, 10-12 (1982).

227) Y. Iwai and S. Omura: Culture conditions for screening of new antibiotics. J. Antibiot., 35, 123-141 (1982).

228) S. Ômura, Y. Tanaka, A. Nakagawa, Y. Iwai, M. Inoue, and T. Tanaka: Irumamycin, a new antibiotic active against phytopathogenic fungi. J. Antibiot., 35, 256-257 (1982).

229) H. Matsubara, K. Miyano, A. Nakagawa, and S. Ômura: Chemical transformation of tylosin, a 16-membered macrolide, and its structure-activity relationship. Chem. Pharm. Bull., 30, 97-110 (1982).

230) S. Ômura, N. Sadakane, and H. Matsubara: Bioconversion and biosynthesis of 16-membered macrolide, and its structure-activity relationship. Chem. Pharm. Bull., 30, 223-229 (1982).

231) Y. Tanaka, H. Tanaka, S. Ômura, K. Araki, and N. Nakayama: Ammonia trapping and stimulation of L-serine production from glycine by magnesium phosphate. Agricult. Biol. Chem., 46, 543-545 (1982).

232) S. Ômura, K. Miyano, H. Matsubara, and A. Nakagawa: Novel dimeric derivatives of leucomycins and tylosin, sixteen-membered macrolides. J. Med. Chem., 25, 271-275 (1982).

233) S. Ômura and R. Oiwa Avermectin and its derivatives (Review article). The Kitasato Medical News, 28, 1-16 (1981).

234) M. Onda, Y. Konda, K. Hinotozawa, and S. Ômura: The alkaloid AM-6201 from Streptomyces xanthochromogenus.. Chem. Pharm. Bull., 30, 1210-1214 (1982).

235) S. Ômura and H. Tanaka: Cell-free biosynthesis of macrolides and other "polyketide" antibiotics (Review article). In "Proceeding of VIth International Fermentation
Symposium and Vth International Symposium on Yeast" 77-82 (1982).

236) S. Ômura, H. Tanaka, J. Inokoshi, H. Sakakibara, and T. Fujiwara: Binding of $\left[{ }^{3} \mathrm{H}\right]$-tetrahydroleucomycin A3 to Escherichia coli ribosomes and the effect of 3"-O-acyl derivatives of leucomycins and on the binding. J. Antibiot., 35, 491-496 (1982).

237) H. Ikeda, H. Tanaka, and S. Ômura: Isolation and characterization of covalently closed circular DNA associated with chromosomal and membrane fraction from Streptomyces ambofaciens.. J. Antibiot., 35, 497-506 (1982).

238) H. Ikeda, H. Tanaka, and S. Ômura: Genetic and biochemical features of spiramycin biosynthesis in Streptomyces ambofaciens - curing, protoplast regeneration and plasmid transfer - . J. Antibiot., 35, 507-516 (1982).

239) N. Imamura, K. Kakinuma, N. Ikekawa, H. Tanaka, and S. Ômura: Biosynthesis of vineomycins $\mathrm{A} 1$ and $\mathrm{B} 2$. J. Antibiot., 35, 602-608 (1982).

240) S. Ômura, Y. Tanaka, H. Tanaka, Y. Takahashi, Y. Iwai, and C. Kitao: Stimulation of leucomycin production by magnesium phosphate and its relevance to nitrogen catabolite regulation (Review article). In "Proceeding of VIth International Fermentation Symposium and Vth International Symposium on Yeast" 181-185 (1982).

241) S. Ômura, Y. Iwai, K. Hinotozawa, Y. Takahashi, J. Kato, and A. Nakagawa: Cervinomycin A1 and A2, new antibiotics active against anaerobes, produced by Streptomyces cervinus sp. nov. J. Antibiot., 35, 645-652 (1982).

242) N. Sadakane, Y. Tanaka, and S. Ômura: Hybrid biosynthesis of derivatives of protylonolide and M-4365 by macrolide-producing microorganisms. J. Antibiot., 35, 680-687 (1982).

243) A. A. Jakubowski, F. S. Guziec, Jr., M. Sugiura, C. C. Tam, M. Tishler, and S. Ômura: Total synthesis of (+)-cerulenin, (+)-tetrahydrocerulenin, and related compounds. J. Org. Chem., 47, 1221-1228 (1982).

244) A. Kawaguchi, H. Tomoda, S. Nozoe, S. Ômura, and S. Okuda: Mechanism of action of cerulenin on fatty acid synthetase. Effect of cerulenin on iodo-acetamide-induced malonyl-CoA decarboxylase activity. J. Biochem., 92, 7-12 (1982).

245) S. Ômura, Y. Takahashi, Y. Iwai, and H. Tanaka: Kitasatosporia, a new genus of the order Actinomycetales. J. Antibiot., 35, 1013-1019 (1982).

246) S. Ômura, H. Tanaka, and M. Tsukui: Biosynthesis of tylosin: Oxidations of 5-O-mycaminosyl-protylonolide at $\mathrm{C}-20$ and C-23 with a cell-free extract from Streptomyces fradiae. Biochem. Biophys. Res. Commun., 107, 554-560 (1982).

247) M. Hayashi, T. Unemoto, S. Minami-Kakinuma, H. Tanaka, and S. Ômura: The mode of action of nanaomycins D and A on a Gram-positive marine bacterium Vibrio alginolyticus. J. 
Antibiot., 35, 1078-1085 (1982).

248) R. Masuma, Y. Tanaka, and S. Ômura: Enhancement of cerulenin production by a natural zeolite, an ammonium ion-trapping agent. J. Antibiot., 35, 1184-1193 (1982).

249) H. Tanaka, R. Oiwa, S. Matsukura, J. Inokoshi, and S. Ômura: Studies on bacterial cell wall inhibitors. $X$. Properties of phospho- $N$-acetylmuramoyl-pentapeptide-transfe rase in peptidoglycan synthesis of Bacillus megaterium and its inhibition by amphomycin. J. Antibiot., 35, 1216-1221 (1982).

250) S. Ômura, Y. Iwai, K. Hinotozawa, H. Tanaka, Y. Takahashi, and A. Nakagawa: OM-704 A, a new antibiotic active against Gram-positive bacteria produced by Streptomyces sp. J. Antibiot., 35, 1425-1429 (1982).

251) H. Tanaka, S. Minami-Kakinuma, and S. Ômura: Biosynthesis of nanaomycin. III. Nanaomycin A formation from nanaomycin D by nanaomycin D reductase via hydroquinone. J. Antibiot., 35, 1565-1570 (1982).

252) S. Ômura, A. Nakagawa, K. Shibata, and H. Sano: The structure of hitachimycin, a novel macrocyclic lactam involving $\beta$-phenylalanine. Tetrahedron Lett., 23, 4713-4716 (1982).

253) S. Ômura, A. Nakagawa, and Y. Tanaka: New macrocyclic antibiotics, irumamycin and hitachimycin (stubomycin). In "Trends in Antibiotic Research" 135-145, Jpn. Antibiot. Res. Assoc., Tokyo (1982).

254) A. Furusaki, N. Hashiba, T. Matsumoto, A. Hirano, Y. Iwai, and S. Ômura: The crystal and molecular structure of staurosporine, an new alkaloid from a Streptomyces strain. Bull. Chem. Soc. Jpn., 55, 3681-3685 (1982).

255) S. Ômura, H. Shimizu, Y. Iwai, K. Hinotozawa, K. Otoguro, H. Hashimoto, and A. Nakagawa: AM-2604, a new antiviral antibiotic produced by a strain of Streptomyces. J. Antibiot., 35, 1632-1637 (1982).

256) V. P. Gullo, S. B. Zimmerman, R. S. Dewey, O. Hensens, P. J. Cassidy, R. Oiwa, and S. Ômura: Factumycin, a new antibiotic (A40A): Fermentation, isolation and antibacterial spectrum. J. Antibiot., 35, 1705-1707 (1982).

257) S. Ômura, A. Nakagawa, and Y. Tanaka: Structure of a new antifungal antibiotic, irumamycin. J. Org. Chem., 47, 5413-5415 (1982).

258) H. Ikeda, M. Inoue, and S. Ômura: Improvement of macrolide antibiotic-producing Streptomycete strains by the regeneration of protoplasts. J. Antibiot., 36, 283-288 (1983).

259) S. Ômura, Y. Iwai, A. Nakagawa, R. Iwata, Y. Takahashi, H. Shimizu, and H. Tanaka: Thiotetromycin, a new antibiotic-taxonomy, production, isolation, and physicochemical and biological properties. J. Antibiot., 36, 109-114 (1983).

260) R. Oiwa, Y. Iwai, Y. Takahashi, K. Kitao, and S. Ômura: Taxonomic studies of a stubomycin (hitachimycin)-producing actinomycete. The Kitasato Arch. Exp. Med., 55, 119-124 (1982).

261) S. Ômura, K. Tsuzuki, A. Nakagawa, and G.
Lukacs: Biosynthetic origin of carbons 3 and 4 of leucomycin aglycone. J. Antibiot., 36, 611-613 (1983).

262) S. Ômura, K. Tsuzuki, Y. Tanaka, H. Sakakibara, M. Aizawa, and G. Lukacs: Valine as a precursor of n-butyrate unit in the biosynthesis of macrolide aglycone. J. Antibiot., 36, 614-616 (1983).

263) N. Sadakane, Y. Tanaka, and S. Ômura: Hybrid biosynthesis of a new macrolide antibiotics by a daunomycin-producing microorganisms. J. Antibiot., 36, 921-922 (1983).

264) S. Ômura, N. Sadakane, Y. Tanaka, and H. Matsubara: Chimeramycins: new macrolide antibiotics produced by hybrid biosynthesis. J. Antibiot., 36, 927-930 (1983).

265) N. Sadakane, Y. Tanaka, and S. Ômura: New 20-membered lactones, irumanolides I and II, produced by a mutant of Streptomyces. J. Antibiot., 36, 931-933 (1983).

266) H. Funabashi, S. Iwasaki, S. Okuda, and S. Ômura: A model study on the mechanism of fatty acid synthetase inhibition by antibiotic cerulenin. Tetrahedron Lett., 24, 2673-2676 (1983).

267) S. Ômura, A. Nakagawa, H. Aoyama, K. Hinotozawa, and H. Sano: The structure of diazaquinomycins $\mathrm{A}$ and $\mathrm{B}$, new antibiotic metabolites. Tetrahedron Lett., 24, 3643-3646 (1983).

268) S. Ômura, A. Nakagawa, H. Aoyama, and Y. Iwai: Karabemycin, a new antimetabolite of glutamine produced by a strain of streptomycete. J. Antibiot., 36, 1129-1135 (1983).

269) H. Sano, M. Inoue, K. Yamashita, R. Okachi, and S. Ômura: Chemical modification of spiramycins. I. Synthesis of the acetal derivatives of neospiramycin I. J. Antibiot., 36, 1336-1344 (1983).

270) Y. Iwai, K. Kimura, Y. Takahashi, K. Hinotozawa, H. Shimizu, H. Tanaka, and S. Ômura: OM-173, new nanaomycin-type antibiotics produced by a strain of Streptomyces. Taxonomy, production, isolation and biological properties. J. Antibiot., 36, 1268-1274 (1983).

271) N. Enoki, K. Tsuzuki, S. Ômura, R. Ishida, and T. Matsumoto: New antimicrobial diterpenes, dictyol $\mathrm{F}$ and epidictyol $\mathrm{F}$, from the brown alga Dictyota dichotoma. Chem. Lett., 1627-1630 (1983).

272) M. Onda, Y. Konda, A. Hatano, T. Hata, and S. Ômura: Structure of carzinophilin. 3. Structure elucidation by nuclear magnetic resonance spectroscopy. 1. J. Am. Chem. Soc., 105, 6311-6312 (1983).

273) K. Tsuzuki and S. Ômura: Syntheses and biological activities of thiotetromycin analogs. J. Antibiot., 36, 1589-1591 (1983).

274) S. Ômura, J. Inokoshi, H. Matsubara, and H. Tanaka: Ribosome-binding activities and antimicrobial activities of tylosin and its related compounds. J. Antibiotics, 36, 1709-1712 (1983).

275) H. Matsubara, J. Inokoshi, A. Nakagawa, H. 
Tanaka, and S. Ômura: Chemical modification of tylosin: synthesis of amino derivatives at C-20 position of tylosin and demycarosyltylosin. J. Antibiot., 36, 1713-1721 (1983).

276) S. Ômura, K. Otoguro, and H. Tanaka: The mode of action of a novel 18-membered macrolide, virustomycin A (AM-2604 A), on Trichomonas foetus. J. Antibiot., 36, 1755-1761 (1983).

277) S. Ômura, A. Nakagawa, R. Iwata, and A. Hatano: Structure of a new antibacterial antibiotic, thiotetromycin. J. Antibiot., 36, 1781-1782 (1983).

278) S. Ômura, N. Imamura, K. Hinotozawa, K. Otoguro, G. Lukacs, R. Faghih, R. Tolmann, B. H. Arison, and J. L. Smith: The structure of virustomycin A. J. Antibiot., 36, 1783-1786 (1983).

279) S. Ômura, Y. Tanaka, H. Mamada, and R. Masuma: Ammonium ion suppresses the biosynthesis of tylosin aglycone by interference with valine catabolism in Streptomyces fradiae. J. Antibiot., 36, 1792-1794 (1983).

280) R. Masuma, Y. Tanaka, and S. Ômura: Ammonium ion-depressed fermentation of tylosin by the use of a natural zeolite and its significance in the study of biosynthetic regulation of the antibiotic. J. Ferm. Technol., 61, 607-614 (1983).

281) S. Ômura: Screening for bioactive substances from microorganisms (Review article). Gekkan Yakuji, 26, 27-33 (1984).

282) Y. Takahashi, Y. Iwai, and S. Ômura: Relationship between cell morphology and the types of diaminopimelic acid in Kitasatosporia setae. J. Gen. Appl. Microbiol., 29, 459-465 (1983).

283) S. Ômura, Y. Tanaka, H. Mamada, and R. Masuma: Effect of ammonium ion, inorganic phosphate and amino acids on the biosynthesis of protylonolide, a precursor of tylosin aglycone. J. Antibiot., 37, 494-502 (1984).

284) H. Tomoda, A. Kawaguchi, S. Ômura, and S. Okuda: Cerulenin resistance in a cerulenin-producing fungus. II. Characterization of fatty acid synthetase from Cephalosporium caerulens. J. Biochem., 95 1705-1712 (1984).

285) H. Tomoda, A. Kawaguchi, T. Yasuhara, T. Nakajima, S. Ômura, and S. Okuda: Cerulenin resistance in a cerulenin-producing fungus. III. Studies on active-site peptides of fatty acid synthetase from Cephalosporium caerulens. J. Biochem., 95, 1713-1723 (1984).

286) S. Ômura, H. Mamada, N.-J. Wang, N. Imamura, R. Oiwa, Y. Iwai, and N. Muto: Takaokamycin, a new peptide antibiotic produced by Streptomyces sp. J. Antibiot., 37, 700-705 (1984).

287) H. Sano, M. Inoue, and S. Ômura: Chemical modification of spiramycins. II. Synthesis and antimicrobial activity of 4'-deoxy derivatives of neospiramycin I and their 12-(z)-isomers. J. Antibiot., 37, 738-749 (1984).

288) H. Sano, T. Sunazuka, H. Tanaka, K. Yamashita,
R. Okachi, and S. Ômura: Chemical modification of spiramycins. III. Synthesis and antibacterial activities of 4"-sulfonates and 4-alkylethers of spiramycin I. J. Antibiot., 37, 750-759 (1984).

289) H. Sano, T. Sunazuka, H. Tanaka, K. Yamashita, R. Okachi, and S. Ômura: Chemical modification of spiramycins. IV. Synthesis and in vitro and in vivo activities of 3",4"-diacylates and 3,3",4"-triacylates of spiramycin I. J. Antibiot., 37, 760-772 (1984).

290) T. Kimura, K. Tsuchiya, and S. Ômura: Prohisin, new thiol protease inhibitor produced by Cephalosporium sp. KM-388. Agricult. Biol. Chem., 48, 1685-1686 (1984).

291) S. Ômura, M. Murata, H. Hanaki, K. Hinotozawa, R. Oiwa, and H. Tanaka: Phosalacine, a new herbicidal antibiotic containing phosphinothricin containing phosphinothricin. Fermentation, isolation, biological activity and mechanism of action. J. Antibiot., 37, 829-835 (1984).

292) S. Ômura, K. Hinotozawa, N. Imamura, and M. Murata: The structure of phosalacine, a new herbicidal antibiotic containing phosphinothricin. J. Antibiot., 37, 939-940 (1984).

293) S. Ômura, H. Matsubara, K. Tsuzuki, and A. Nakagawa: Chemical modification of tylosin thioether derivatives of tylosin and demycarosyltylosin. J. Antibiot., 37, 1007-1015 (1984).

294) Y. Takahashi, T. Kuwana, Y. Iwai, and S. Ômura: Some characteristics of aerial and submerged spores of Kitasatosporia setalba.. J. Gen. Appl. Microbiol., 30, 223-229 (1984).

295) M. Onda, Y. Konda, A. Hatano, T. Hata, and S. Ômura: Structure of carzinophilin. IV. Structure elucidation by nuclear magnetic resonance spectroscopy (2). Chem. Pharm. Bull., 32, 2995-3002 (1984).

296) S. Ômura, H. Sano, S. Yamamoto, M. Tsuzuki, and H. Tanaka: Studies on two deoxygenases involved in the synthesis of tylosin in Streptomyces fradiae. Biochim. Biophys. Acta, 802, 141-147 (1984).

297) H. Ikeda, M. Inoue, H. Tanaka, and S. Ômura: Interspecific protoplast fusion among macrolide producing streptomycetes. J. Antibiot., 37, 1224-1230 (1984).

298) S. Ômura, K. Miyano, A. Nakagawa, H. Sano, K. Komiyama, and I. Umezawa: Chemical modification and antitumor activity of herbimycin A 8,9-epoxide, 7,9-cyclic carbamate, and 17 or 19-amino derivatives. J. Antibiot. 37, 1264-1267 (1984).

299) S. Ômura, M. Murata, N. Imamura, Y. Iwai, and H. Tanaka: Oxetin, a new antimetabolite from an actinomycete. Fermentation, isolation, structure and biological activity. J. Antibiot., 37, 1324-1332 (1984).

300) S. Ômura, A. Taki, K. Matsuda, and Y. Tanaka: Ammonium ions suppress the amino acid metabolism involved in the biosynthesis of protylonolide in a mutant of Streptomyces fraidae. J. Antibiot., 37, 1362-1369 (1984). 
301) Y. Tanaka, R. Masuma, and S. Ômura: Control of ammonium ion level of efficient nanaomycin production. J. Antibiot., 37, 1370-1375 (1984).

302) S. Ômura, Y. Tanaka, Y. Takahashi, I. Chia, M. Inoue, and Y. Iwai: Irumamycin, an antifungal 20-membered macrolide produced by a Streptomyces. Taxonomy, fermentation and biological properties. J. Antibiot., 37, 1572-1578 (1984).

303) S. Ômura and A. Nakagawa: Macrolide antibiotics (Review article). Pharmacia, 20, 1226-1232 (1984).

304) K. Tsuzuki, M. Akeyoshi, and S. Ômura: Sulfur-extrusive rearrangement of $\alpha$-acylthio ester by lithium amide. Bull. Chem. Soc. Jpn., 58, 395-396 (1985).

305) S. Ômura and H. Tanaka: Production and antimicrobial activity of macrolides (Review article). In "Macrolide Antibiotics" (Ed. by S. Ômura) 3-35, Academic Press (1984).

306) A. Nakagawa and S. Ômura: Structure and stereochemistry of macrolides (Review article). In "Macrolide Antibiotics" (Ed. by S. Omura) 37-84, Academic Press (1984).

307) S. Ômura and Y. Tanaka: Biochemistry, regulation, and genetics of macrolide production (Review article). In "Macrolide Antibiotics" (Ed. by S. Omura) 199-229, Academic Press (1984).

308) S. Ômura and H. Tanaka: Production, structure, and antifungal activity of polyene macrolides (Review article). In "Macrolide Antibiotics" (Ed. by S. Omura) 351-404, Academic Press (1984).

309) S. Ômura: Production, structure, and biological properties of macrolide-like antibiotics (Review article). In "Macrolide Antibiotics" (Ed. by S. Omura) 509-552, Academic Press (1984).

310) Y. Iwai and S. Ômura: Taxonomic properties of the genus Kitasatosporia (Review article). Actinomycetol., No. 45, 12-19 (1984).

311) H. Sano, H. Tanaka, K. Yamashita, R. Okachi, and S. Ômura: Chemical modification of spiramycins. V. Synthesis and antibacterial activity of 3'- or 4"'-de- $N$-methylspiramycin I and their $\mathrm{N}$-substituted derivatives. J. Antibiot., 38, 186-196 (1985).

312) S. Ômura and H. Tomoda: Antibiotic cerulenin, its action mechanism in fatty acid synthetase and application as an inhibitor to polyketide biosynthesis. Oil Chem., 34, 2-9 (1985).

313) Y. Takahashi, Y. Iwai, and S. Ômura: Two new species of the genus Kitasatosporia, Kitasatosporia phosalacinea sp. nov. and Kitasatosporia griseola sp. nov. J. Gen. Appl. Microbiol., 30, 377-387 (1984).

314) H. Takeshima, J. Inokoshi, M. Namiki, J. Shimada, and S. Ômura: Structural analysis of the gene coding for hepatitis B virus surface antigen and its product. J. Gen. Virol., 66, 195-200 (1985).

315) S. Ômura and Y. Tanaka: Control of ammonium ion level in antibiotic fermentation (Review article). In "Biological Biochemical, and Biomedical Aspects of Actinomycetes" (Eds. by L. O.-Ortiz, L. F. Bojalil, and V. Yakoleff) 367-380, Academic press (1985).

316) D. A. Hopwood, f. Malphartida, H. M. Kieser, H. Ikeda, J. Duncan, I. Fujii, B. A. M. Rudd, H. G. Floss, and S. Ômura: Production of 'hybrid' antibiotics by genetic engineering. Nature, 314, 642-644 (1985).

317) S. Ômura, A. Nakagawa, N. Imamura, K. Kushida, C.-M. Liu, L. H. Sello, and J. W. Westley: Structure of a new macrolide antibiotic, X-4952B. J. Antibiot., 38, 674-676 (1985).

318) H. Yamada, K. Ohtani, H. Kiyohara, J.-C. Cyong, Y. Otsuka, Y. Ueno, and S. Ômura: Purification and chemical properties of anti-complementary polysaccharide from the leaves of Altemisia princeps. Planta Medica, 1985, 121-126.

319) Y. Iwai, H. Shimizu, and S. Ômura: A view of the screening for antiviral antibiotics (Review article). Kagaku to Seibutsu, 23, 379-385 (1985).

320) S. Ômura, H. Sano, and T. Sunazuka: Structure-activity relationships of spiramycins. J. Amtimicrob. Chemother., 16, Suppl. A, 1-11 (1985).

321) S. Ômura, Y. Takahashi, Y. Iwai, and H. Tanaka: Revised nomenclature of Kitasatosporia setalba.. Int. J. System. Bacteriol., 35, 221 (1985).

322) H. Tanaka, I. Moriguchi, S. Hirono, and S. Omura: Quantitative structure-activity relationships of $O$-acyl derivatives of leucomycin for antimicrobial and ribosome-binding activities. Chem. Pharm. Bull., 33, 2803-2808 (1985).

323) S. Ômura, N. Imamura, H. Kuga, H. Ishikawa, Y. Yamazaki, K. Okano, K. Kimura, Y. Takahashi, and H. Tanaka: Adechlorin, a new adenosine deaminase inhibitor containing chlorine. Production, isolation and properties. J. Antibiot., 38, 1008-1015 (1985).

324) T. Tsuge, S. Nishimura, S. Ômura, K. Kohmoto, and $\mathrm{H}$. Otani: Metabolic regulation of host-specific toxin production in Alternaria alternata pathogens (2). Suppression of toxin production from germinating spores by chemical treatment. Ann. Phytopath. Soc. Jpn., 51, 277-284 (1985).

325) N. Imamura, M. Murata, T. Yao, R. Oiwa, H. Tanaka, and S. Ômura: Occurrence of 1,2,4-triazole ring in actinomycetes. J. Antibiot., 38, 1110-1111 (1985).

326) S. Ômura, M. Murata, K. Kimura, S. Matsukura, T. Nishihara, and H. Tanaka: Screening for new antifolates of microbial origin and a new antifolate AM-8402. J. Antibiot., 38, 1016-1024 (1985).

327) M. Murata, T. Miyasaka, H. Tanaka, and S. Ômura: Diazaquinomycin A, a new antifolate antibiotic, inhibits thymidylate synthase. J. Antibiotics, 38, 1025-1033 (1985).

328) A. Nakagawa, H. Tomoda, M. V. Hao, K. Okano, Y. Iwai, and S. Ômura: Antiviral 
activities of pentalenolactones. J. Antibiot., 38, 1114-1115 (1985).

329) A. Nakagawa, Y. Tanaka, K. Otoguro, and S. Ômura: A new antifungal antibiotic, 3'- $O$-decarbamoylirumamycin. J. Antibiot., 38, 1266-1269 (1985).

330) S. Ômura, R. Iwata, Y. Iwai, S. Taga, Y. Tanaka, \& H. Tomoda: Luminamicin, a new antibiotic. Production, isolation and physicochemical and biological properties. J. Antibiot., 38, 1322-1326 (1985).

331) H. Sano, T. Sunazuka, H. Tanaka, K. Yamashita, R. Okachi, and S. Ômura: Chemical modification of spiramycins. VI. synthesis and antibacterial activities of 3,3 "-di- $O$-acyl-4"- $O$-sulfonyl and 3,3"-di- $O$-acyl-4"- $O$-alkyl derivatives of spiramycin I. J. Antibiot., 38, 1350-1358 (1985).

332) S. Ômura, K. Tsuzuki, Y. Iwai, M. Kishi, S. Watanabe, and H. Shimizu: Anticoccidial activity of frenolicin B and its derivatives. J. Antibiot., 38, 1447-1448 (1985).

333) S. Ômura, K. Tsuzuki, T. Sunazuka, H. Toyota, I. Takahashi, and Z. Itoh: Gastrointestinal motor-stimulating activity of macrolide antibiotics and the structure-activity relationship. J. Antibiot., 38, 1631-1632 (1985).

334) A. Nakagawa, T.-S. Wu, P. J. Keller, J. P. Lee, S. Ômura, and H. G. Floss: Biosynthesis of asukamycin. Formation of the 2-amino-3-hydroxycyclopent-2-enone moiety. J. Chem. Soc., Chem. Commun., 1985, 519-521 (1985).

335) J. M. Beale, J. P. Lee, A. Nakagawa, S. Ômura, and H. G. Floss: Biosynthesis of the antibiotic reductinomycin. J. Am. Chem. Soc., 108, 331-332 (1986).

336) S. Ômura, H. Tanaka, H. Kuga, and N. Imamura: Adecypenol, a unique adenosine deaminase inhibitor containing homopurine and cyclopentaene rings. J. Antibiot., 39, 309-310 (1986).

337) S. Ômura and Y. Tanaka: Biosynthesis of tylosin and its regulation by ammonium and phosphate (Review article). In "Regulation of Secondary Metabolite Formation" (Eds. by H. Kleinkauf, H. V. Dohren, and H. Dornauer) 306-332, VCH Verlagsgesellschaft mbH (1985).

338) K. Shibata, S. Satsumabayashi, H. Sano, K. Komiyama, A. Nakagawa, and S. Ômura: Chemical modification of herbimycin A. Synthesis and in vivo antitumor activities of halogenated and other related derivatives of herbimycin A. J. Antibiot., 39, 415-423 (1986).

339) Y. Tanaka, A. Taki, R. Masuma, and S. Ômura: Mechanism of nitrogen regulation of protylonolide biosynthesis in Streptomyces fradiae. J. Antibiot., 39, 813-821 (1986).

340) S. Ômura, H. Ikeda, F. Marpartida, H. M. Kieser, and D. A. Hopwood: Production of new hybrid antibiotics, mederrhodins $\mathrm{A}$ and $\mathrm{B}$, by a genetically engineered strain. Antimicrob. Agents Chemother., 29, 13-19 (1986).

341) S. Ômura, M. Murata, K. Kimura, T. Nishihara, and H. Tanaka: Screening for new antifolates of microbial origin. In "Recent Advances in Chemotherapy, Proceedings of the 14th Int. Cong. Chemother." (Ed. by J. Ishigami) 327-328, University of Tokyo Press (1985).

342) S. Ômura and Y. Tanaka: Macrolide Antibiotics (Review article). In "Bacteriology" (Eds. by H.-J. Rehm and G. Reed) 4, 360-391, VCH Verlagsgesellschaft (1986).

343) S. Ômura, N. Imamura, K. Kawakita, Y. Mori, Y. Yamazaki, R. Masuma, Y. Takahashi, H. Tanaka, L.-Y. Huang \& H. B. Woodruff: Ahpatinins, new acid proteases inhibitors containing

4-amino-3-hydroxy-5-phenylpentanoic acid. J. Antibiot., 39, 1079-1085 (1986).

344) S. Ômura, A. Nakagawa, N. Fukamachi, K. Otoguro, and B. Kobayashi: Aggreceride, a new platelet aggregation inhibitor from Streptomyces. J. Antibiot., 39, 1180-1181 (1986).

345) Y. Kawahata, S. Takatsuto, N. Ikekawa, M. Murata, and S. Ômura: Synthesis of a new amino acid-antibiotic, oxetin and its three stereoisomers. Chem. Pharm. Bull., 34, 3102-3110 (1986).

346) H. Tomoda, R. Iwata, Y. Takahashi, Y. Iwai, R. Oiwa, and S. Ômura: Lustromycin, a new antibiotic produced by Streptomyces sp. J. Antibiot., 39, 1205-1210 (1986).

347) S. Ômura, H. Tomoda, Q. M. Xu, Y. Takahashi, and Y. Iwai: Triacsins, new inhibitors of acyl-CoA synthetase produced by Streptomyces. J. Antibiot., 39, 1211-1218 (1986).

348) S. Ômura, H. Ishikawa, H. Kuga, N. Imamura, S. Taga, Y. Takahashi, and H. Tanaka: Adecypenol, a unique adenosine deaminase inhibitor containing homopurine and cyclopentene rings. Taxonomy, production and enzyme inhibition. J. Antibiot., 39, 1219-1224 (1986).

349) K. Tsuzuki, Y. Iwai, S. Ômura, H. Shimizu, and N. Kitajima: Nanaomycins production by a frenolicin B producing strain. J. Antibiot., 39, 1343-1345 (1986).

350) S. Ômura, A. Nakagawa, K. Kushida, and G. Lukacs: Structure of cervinomycin, a novel antianaerobic antibiotic. J. Am. Chem. Soc., 108, 6088-6089 (1986).

351) S. Ômura, N. Imamura, R. Oiwa, H. Kuga, R. Iwata, R. Masuma, and Y. Iwai: Clostomicins, new antibiotics produced by Micromonospora echinospora subsp. armeniaca subsp. nov. I. Production, isolation, and physicochemical and biological properties. J. Antibiot., 39, 1407-1412 (1986).

352) Y. Takahashi, Y. Iwai, and S. Ômura: Clostomicins, new antibiotics produced by Micromonospora echinospora subsp. armeniaca subsp. nov. II. Taxonomic study of the producing microorganism. J. Antibiot., 39, 1413-1418 (1986).

353) S. Ômura: Philosophy of new drug discovery (Review article). Microbiol. Rev., 50, 259-379 (1986). 
354) H. Yamada, Y. Otsuka, and S. Omura: Structural characterization of anti-complementary polysaccharides from the leaves of Artemisia princeps. Planta Medica, 1986, 311-314.

355) R. Masuma, Y. Tanaka, H. Tanaka, and S. Ômura: Production of nanaomycin and other antibiotics by phosphate-depressed fermentation using phosphate-trapping agents. J. Antibiot., 39, 1557-1564 (1986).

356) K. Shibata, S. Satsumabayashi, A. Nakagawa, and S. Ômura: The structure and cytocidal activity of herbimycin C. J. Antibiot., 39, 1630-1633 (1986).

357) A. Nakagawa, Y. Iwai, H. Shimizu, and S. Omura: Enhanced antimicrobial activity of acetyl derivatives of cervinomycin. J. Antibiot., 39, 1636-1638 (1986).

358) S. Ômura: Studies on macrolide and new antibiotics (Review article). Yakugaku Zasshi, 106, 729-757 (1986).

359) M. Di Giambattista, P. Vannuffel, T. Sunazuka, J. Jacob, S. Ômura, and C. Cocito: Antagonistic interactions of macrolides and synergimycins on bacterial ribosomes. J. Am. Chemother., 18, 307-315 (1986).

360) P. S.-Nakagawa, Y. Fukushi, K. Maebashi, N. Imamura, Y. Takahashi, Y. Tanaka, H. Tanaka, and S. Ômura: Izupeptins $A$ and $B$, new glycopeptide antibiotics produced by an actinomycete. J. Antibiot., 39, 1719-1723 (1986).

361) K. Tsuzuki, H. Matsubara, A. Nakagawa, and S. Ômura: Syntheses and antimicrobial activities of 9-O-acyl derivatives of tylosin and demycarosyl-tylosin. J. Antibiot., 39, 1784-1787 (1986).

362) Y. Tanaka, K. Hirata, Y. Takahashi, Y. Iwai, and S. Ômura: Globopeptin, a new antifungal peptide antibiotic. J. Antibiot., 40, 242-244 (1987).

363) M. Murata, H. Tanaka, and S. Omura: 7-Hydro-8-methyl pteroylglutamyl-glutamic acid, a new anti-folate from an actinomycete. Fermentation, isolation, structure and biological activity. J. Antibiot., 40, 251-257 (1987).

364) A. Nakagawa, S. Ômura, K. Kushida, H. Shimizu, and G. Lukacs: Structure of cervinomycin, a novel xanthone antibiotic active against anaerobe and mycoplasma. J. Antibiot., 40, 301-308 (1987).

365) S. Ômura, K. Otoguro, N. Imamura, H. Kuga, Y. Takahashi, R. Masuma, Y. Tanaka, and $\mathrm{H}$. Tanaka: Jietacins A and B, new nematocidal antibiotics from a Streptomyces sp. Taxonomy, isolation, and physico-chemical and biological properties. J. Antibiot., 40, 623-629 (1987).

366) S. Ômura, H. Tomoda, H. Kumagai, M. D. Greenspan, J. B. Yodkovitz, J. S. Chen, A. W. Alberts, I. Martin, S., Mochales, R. L. Monaghan, J. C. Chabala, R. E. Schwartz, and A. A. Patchett Potent inhibitory effect of antibiotic $1233 \mathrm{~A}$ on cholesterol biosynthesis which specifically blocks 3-hydroxy-3-methyl-glutaryl coenzyme A synthase. J. Antibiot., 40, 1365-1367 (1987).
367) S. Ômura and M. Murata: Antimetabolites from microorganisms (Review article). Radioisotopes, 36, 63 (1987).

368) T. Teshima, M. Nishikawa, I. Kubota, T. Shiba, and S. Ômura: Structure of an antibiotic, AM-2504. In "Peptide Chemistry 1986" (Ed. by T. Miyazawa) 169-174, Protein Research Foundation, Osaka (1987).

369) A. Nakagawa, N. Fukamachi, K. Yamaki, M. Hayashi, S. Oh-ishi, B. Kobayashi, and S. Ômura: Inhibition of platelet aggregation by medermycin and its related isochromanequinone antibiotics. J. Antibiot., 40, 1075-1076 (1987).

370) Y. Takahashi and S. Ômura: Kitasatosporia, a genus of the order Actinomycetales.. The Kitasato Arch. Exp. Med., 60, 1-14 (1987).

371) S. Taga, Y. Takahashi, Y. Iwai, and S. Ômura: Taxonomic study of luminamicin-producing actinomycete strain OMR-59. The Kitasato Arch. Exp. Med., 60, 15-24 (1987).

372) H. Tomoda, K. Igarashi, Y. Tanaka, S. Ômura, H. Funabashi, and S. Okuda: Biosynthetic preparation of labeled cerulenin with high specific radioactivity. J. Antibiot., 40, 1457-1460 (1987).

373) S. Ômura, K. Tsuzuki, T. Sunazuka, S. Marui, H. Toyoda, N. Inatomi, and Z. Itoh: Macrolides with gastrointestinal motor stimulating activity. J. Med. Chem., 30, 1941-1943 (1987).

374) H. Tomoda, K. Igarashi, and S. Ômura: Inhibition of acyl-CoA synthetase by triacsins. Biochim. Biophys. Acta, 921, 595-598 (1987).

375) S. Ômura, A. Nakagawa, T. Fujimoto, K. Saito, K. Otoguro, and J. C. Walsh: Hygromycin A, an antitreponemal substance. I. Screening method and therapeutic effect for Treponema hyodysenteriae caused infection in CF-1 mice. J. Antibiot., 40, 1619-1626 (1987).

376) A. Nakagawa, T. Fujimoto, S. Ômura, J. C. Walsh, R. L. Stotosh, and B. George: Hygromycin A, an antitreponemal substance. II. Therapeutic effect for swine dysentery. J. Antibiot., 40, 1627-1635 (1987).

377) H. Tomoda, H. Kumagai, H. Tanaka, and S. Ômura: F-244 specifically inhibits 3-hydroxy-3-methyl-glutaryl coenzyme A synthase. Biochim. Biophys. Acta, 922, 351-356 (1987).

378) K. Komiyama, Y. Hirokawa, H. Yamaguchi, S. Funayama, K. Masuda, Y. Anraku, I. Umezawa, and S. Ômura: Antitumor activity of trienomycin A on murine tumors. J. Antibiot., 40, 1768-1772 (1987).

379) R. Masuma, K. Okuyama, Y. Tanaka, R. Hirose, H. Tomoda, Y. Iwai, and S. Ômura: A new agar medium suitable for screening of anticlostridium agents. J. Antibiot., 40, 1773-1775 (1987).

380) H. Yamada, M. Yoshino, T. Matsumoto, T. Nagai, H. Kiyohara, J.-C. Cyong, A. Nakagawa, H. Tanaka, and S. Ômura: Effects of phytosterols on anti-complementary activity. Chem. Pharm. Bull., 35, 4851-4855 (1987).

381) H. Ikeda, H. Kotaki, and S. Ômura: Genetic studies of avermectin biosynthesis in 
Streptomyces avermitilis. J. Bacteriol., 169, 5615-5621 (1987).

382) H. Tomoda, H. Kumagai, Y. Takahashi, Y. Tanaka, Y. Iwai, and S. Ômura: F-244 $(1233 \mathrm{~A})$, a specific inhibitor of 3-hydroxy-3-methylglutaryl coenzyme A synthase: Taxonomy of producing strain, fermentation, isolation and biological properties. J. Antibiot., 41, 247-249 (1988).

383) K. Otoguro, A. Nakagawa, and S. Ômura: Setamycin, a 16-membered macrolide antibiotic identification and nematocidal activity. J. Antibiot., 41, 250-252 (1988).

384) Y. Tanaka, K. Kimura, Y. Komagata, K. Tsuzuki, H. Tomoda, and S. Ômura: Radioimmuno-assay for erythromycin derivatives. J. Antibiot., 41, 258-260 (1988).

385) Y. Konda, A. Nakagawa, Y. Harigaya, M. Onda, R. Masuma, and S. Ômura: Aurantinin B, a new antimicrobial antibiotic from bacterial origin. J. Antibiot., 41, 268-270 (1988).

386) Y. Kondo, K. Torii, S. Ômura, and Z. Itoh: Erythromycin and its derivatives with motilin-like biological activities inhibit the specific binding of ${ }^{125}$ I-motilin to duodenal muscle. Biochem. Biophys. Res. Commun., 150, 877-882 (1988).

387) Y. Takahashi, Y. Tanaka, Y. Iwai, and S. Ômura: Promicromonospora sukumoe sp. nov., a new species of the Actinomycetales. J. Gen. Appl. Microbiol., 33, 507-519 (1987).

388) H. Ikeda, H. Kotaki, H. Tanaka, and S. Ômura: Antimicrob. Agents Chemother., 32, 282-284 (1988).

389) K. Otoguro, R. Oiwa, Y. Iwai, H. Tanaka, and S. Ômura: Screening for new antitrichomonas substances of microbial origin and antitrichomonal activity of trichostatin A. J. Antibiot., 41, 461-468 (1988).

390) K. Otoguro, Z.-X. Liu, K. Fukuda, Y. Li, Y. Iwai, H. Tanaka, and S. Ômura: Screening for new nematocidal substances of microbial origin by a new method using the pine wood nematode. J. Antibiot., 41, 573-575 (1988).

391) K. Shibata, S. Satsumabayashi, H. Sano, K. Komiyama, A. Nakagawa, and S. Ômura: Chemical modification of hitachimycin. Synthesis, antimicrobial, cytocidal and in vivo antitumor activities of hitachimycin derivatives. J. Antibiot., 41, 614-623 (1988).

392) T. Teshima, M. Nishikawa, I. Kubota, T. Shiba, Y. Iwai, and S. Ômura: The structure of an antibiotic, dityromycin. Tetrahedron Lett., 29, 1963-1966 (1988).

393) S. Ômura and A. Nakagawa: Antibiotics-structure elucidation and production of new substances using biosynthetic means (Review article). J. Syn. Org. Chem., Jpn., 46, 490-500 (1988).

394) H. Iwase, I. Ishii, K. Ishihara, Y. Tanaka, S. Ômura, and K. Hotta: Release of oligosaccharides possessing reducing-endo- $\mathrm{N}$-acetyl-galactosamine from mucus glycoprotein in Streptomyces sp. $\mathrm{OH}-11242$ culture medium through action of endo-type of glycosidase. Biochem. Biophys. Res. Commun., 151, 422-428 (1988).

395) A. Nakagawa, Y. Konda, A. Hatano, Y. Harigaya, M. Onda, and S. Ômura: Structure and biosynthesis of novel antibiotics, aurantinins A and B produced by Bacillus aurantinus.. J. Org. Chem. , 53, 2660-2661 (1988).

396) S. Ômura, A. Nakagawa, N. Fukamachi, M. Miura, Y., Takahashi, K. Komiyama, and B. Kobayashi: OM-4842, a new platelet aggregation inhibitor from Streptomyces. J. Antibiot., 41, 812-813 (1988).

397) Y. Uehara, Y. Murakami, K. Suzukake-Tsuchiya, Y. Moriya, H. Sano, K. Shibata, and S. Omura: Effects of herbimycin derivatives on src oncogene function in relation to antitumor activity. J. Antibiot., 41, 831-834 (1988).

398) J. M. Beale, R. E. Herrold, H. G. Floss, R. Thiericke, A. Zeeck, A. Nakagawa, and S. Omura: Studies on the biosynthesis of the $\mathrm{m}-\mathrm{C}_{7} \mathrm{~N}$ unit in the antibiotics manumycin and asukamycin. J. Am. Chem. Soc., 110 4435-4437 (1988).

399) Y. Morimoto, K. Oda, H. Shirahama, T. Matsumoto, and S. Ômura: Assignment of absolute configuration for virantmycin and synthesis of its antipode. Chem. Lett., 909-912 (1988).

400) S. Funayama, Y. Anraku, A. Mita, Z.-B. Yang, K. Shibata, K. Komiyama, I. Umezawa, and S. Ômura: Structure-activity relationship of a novel antitumor ansamycin antibiotic trienomycin A and related compounds. J. Antibiot., 41, 1223-1230 (1988).

401) S. Ômura: Search for bioactive compounds from microorganisms-strategies and methods(Review article). In "Biology of Actinomycetes '88" (Eds. by Y. Okami, T. Beppu, and H. Ogawara) 26-32, Jpn. Scientific Soc. Press (1988).

402) Y. Tanaka and S. Ômura: Regulation of biosynthesis of polyketide antibiotics (Review article). In "Biology of Actinomycetes '88" (Eds by Y. Okami, T. Beppu, and H. Ogawara) 418-423, Jpn. Scientific Soc. Press (1988).

403 ) Z. Itoh and S. Ômura: Effect of RU 28965, a new macrolide antibiotic, on gastrointestinal contractile activity: side-effects in the digestive tract. Chemotherapy, 36, 104-115 (1988).

404) S. Ômura: Penicillin. (Review article) Kagakudojin, 44, 20-21 (1989).

405) S. Ômura, H. Tomoda, K. Kimura, D.-Z. Zhen, H. Kumagai, K. Igarashi, N. Imamura, Y. Takahashi, Y. Tanaka, and Y. Iwai: Atpenins, new antifungal antibiotics produced by Penicillium sp. Production, isolation, physicochemical and biological properties. J. Antibiot., 41, 1769-1773 (1988).

406) S. Ômura, Y. Tanaka, K. Hisatome, S. Miura, Y. Takahashi, A. Nakagawa, H. Imai, and H. B. Woodruff: Phthoramycin, a new antibiotic active against a plant pathogen, Phytophthora sp. J. Antibiot., 41, 1910-1912 (1988).

407) N. Imamura, H. Kuga, K. Otoguro, H. Tanaka, 
and S. Ômura: Structures of jietacins: union $\alpha, \beta$-unsaturated azoxy antibiotics. J. Antibiot., 42, 156-158 (1989).

408) H. Tanaka, K. Kawakita, H. Suzuki, P. Spiri-Nakagawa, and S. Ômura: The mode of action of cervinomycin in Staphylococcus aureus. J. Antibiot., 42, 431-439 (1989).

409) H. Nomoto, S. Katsumata, K. Takahashi, S. Funayama, K. Komiyama, I. Umezawa, and S. Ômura: Structural studies on minor components of trienomycin group antibiotics trienomycins D and E. J. Antibiot., 42, 479-481 (1989).

410) Y. Takahashi, Y. Iwai, H. Tomoda, R. Nimura, T. Kinoshita, and S. Ômura: Optical resolution of 2,6-diaminopimelic acid stereoisomers by high performance liquid chromatography for the chemotherapy of actinomycete strains. J. Gen. Appl. Microbiol., 35, 27-32 (1989).

411) K. Shibata, S. Satsumabayashi, H. Sano, K. Komiyama, Y. Z.-Bo, A. Nakagawa, and S. Ômura: Chemical modification of hitachimycin. II. Synthesis and antitumor activities of carbonate derivatives. J. Antibiot., 42, 718-726 (1989).

412) K. Tsuzuki, T. Yokozuka, M. Murata, H. Tanaka, and S. Ômura: Synthesis and biological activity of analogues of diazaquinomycin A, a new thymidylate synthase inhibitor. J. Antibiot., 42, 727-737 (1989).

413) H. Takeshima, J. Inokoshi, Y. Takada, H. Tanaka, and S. Ômura: A deacylation enzyme for aculeacin A, a neutral lipopeptide antibiotic, from Actinoplanes utahensis: Purification and characterization. J. Biochem., 105, 606-610 (1989).

414) H. Funabashi, A. Kawaguchi, H. Tomoda, S. Ômura, S. Okuda, and S. Iwasaki: Binding site of cerulenin in fatty acid synthetase. J. Biochem., 105, 751-755 (1989).

415) H. Tanaka and S. Ômura: New adenosine deaminase inhibitors, adechlorin and adecypenol. (Review article). In "Nobel Microbial Products for Medicine and Agriculture" (Eds. by A. L. Demain, G. A. Somkuti, J. C. Hunter-Cevera, and H. W. Rossmoore) 67-72, Elsevier (1989).

416) H. Tomoda and S. Ômura: Triacsins, acyl-CoA synthetase inhibitors and F-244, a hydroxy-methylglutaryl-CoA synthase inhibitors. In "Novel Microbial Products for Medicine and Agriculture" (Eds. by A. L. Demain, G. A. Somkuti, J. C. Hunter-Cevera, and H. W. Rossmoore) 171-177, Elsevier (1989).

417) E. J. Hartman, S. Ômura, and M. Laposata: Triacsin C, a differential inhibitor of arachidonyl-CoA synthetase and nonspecific long chain acyl-CoA synthetase. Prostaglandins, 37, 655-671 (1989).

418) S. Funayama, S. Eda, K. Komiyama, S. Ômura, and T. Tokunaga: Structure of phenazinomycin, a novel antitumor antibiotic. Tetrahedron Lett., 30, 3151-3154 (1989).

419) S. Ômura, S. Eda, S. Funayama, K. Komiyama, Y. Takahashi, and H. Boyd Woodruff: Studies on a novel antitumor antibiotic, phenazinomycin: Taxonomy, fermentation, isolation, and physico-chemical and biological characteristics. J. Antibiot., 42, 1037-1042 (1989).

420) K. Shibata, S. Satsumabayashi, H. Sano, K. Komiyama, Y. Zhi-Bo, A. Nakagawa, and S. Ômura: Chemical modification of hitachimycin. III. Synthesis and antitumor activities of amino acyl derivatives. J. Antibiot., 42, 1114-1123 (1989).

421) M. Debono, K. E. Willard, H. A. Kirst, J. A. Wind, G. D. Crouse, E. V. Tao, J. T. Vicenzi, F. T. Counter, J. L. Ott, E. E. Ose, and S. Ômura: Synthesis and antimicrobial evaluation of 20-deoxy-20-(3,5-dimethylpiperidinyl)-desmyco sin (tilmicosin, EL-870) and related cyclic amino derivatives. J. Antibiot., 42, 1253-1267 (1989).

422) H. Imai, A. Nakagawa, and S. Ômura: Biosynthesis of the antibiotics okilactomycin. J. Antibiot., 42, 1321-1323 (1989).

423) A. Nakagawa, S. Miura, H. Imai, N. Imamura, and S. Omura: Structure and biosynthesis of a new antifungal antibiotic, phthoramycin. J. Antibiot., 42, 1324-1327 (1989).

424) K. Komiyama, S. Funayama, Y. Anraku, A. Mita, Y. Takahashi, S. Ômura, and H Shimasaki: Isolation of isoflavonoids possessing antioxidant activity from the fermentation broth of Streptomyces sp. J. Antibiot., 42, 1344-1349 (1989).

425) S. Funayama, Y. Anraku, A. Mita, K. Komiyama, and S. Ômura: Structural study of isoflavonoids possessing antioxidant activity isolated from the fermentation broth of Streptomyces sp. J. Antibiot., 42, 1350-1355 (1989).

426) K. Tsuzuki, T. Sunazuka, S. Marui, H. Toyoda, S. Ômura, N. Inatomi, and Z. Itoh: Motilides, macrolides with gastrointestinal motor stimulating activity. I. $O$-Substituted and tertiary $N$-substituted derivatives of 8,9-anhydro-erythromycin A 6,9-hemiacetal. Chem. Pharm. Bull., 37, 2687-2700 (1989).

427) T. Sunazuka, K. Tsuzuki, S. Marui, H. Toyoda, S. Ômura, N. Inatomi, and Z. Itoh: Motilides, macrolides with gastrointestinal motor stimulating activity. II. Quaternary $\mathrm{N}$-substituted derivatives of 8,9-anhydroerythromycin A 6,9-hemiacetal and 9,9-dihydroerythromycin A 6,9-epoxide. Chem. Pharm. Bull., 37, 2701-2709 (1989).

428) T. Lee, J. Inokoshi, M. Namiki, H. Takeshima, and S. Ômura: Production of hepatitis B virus surface antigen containing pre-S1 and pre-S2 domains by chinese hamster ovary cells. Arch. Virol., 106, 151-158 (1989).

429) H. A. Kirst, K. E. Willard, M. Debono, J. E. Toth, B. A. Truedell, J. P. Leeds, J. L. Ott, A. M. Felty-Duckworth, F. T. Counter, E. E. Ose, G. D. Crouse, J. M. Tustin, and S. Ômura: Structure-activity studies of 20-deoxo-20-amino derivatives of tylosin-related macrolides. J. Antibiot., 42, 1673-1683 (1989).

430) H. Tanaka, K. Kawakami, Z.-B. Yang, K. Komiyama, and S. Ômura: Potentiation of cytotoxicity and antitumor activity of adenosine analogs by the adenosine deaminase inhibitor adecypenol. J. Antibiot., 42, 1722-1724 (1989). 
431) S. Funayama, M. Ishibashi, Y. Anraku, M. Miyauchi, H. Mori, K. Komiyama, and S. Ômura: Novel cytocidal antibiotics, glucopiericidinols A1 and A2. Taxonomy, fermentation, isolation, structure elucidation and biological characteristics. J. Antibiot., 42, 1734-1740 (1989).

432) R. Masuma, D.-Z. Zhen, Y. Tanaka, and S. Ômura: Site of regulation of nanaomycin biosynthesis by inorganic phosphate. J. Antibiot., 43, 83-87 (1990).

433) S. Funayama, M. Ishibashi, Y. Anraku, K. Komiyama, and S. Ômura: Structures of novel antibiotics, furaquinocins $\mathrm{A}$ and B. Tetrahedron Lett., 30, 7427-7430 (1989).

434) N. Inatomi, H. Satoh, Y. Maki, N. Hashimoto, Z. Itoh, and S. Ômura: An erythromycin derivative, EM-523, induces motilin-like gastrointestinal motility in dogs. Pharmacol. and Exp. Ther., 251, 707-712 (1989).

$435)$ A. B. Smith, III, J. L. Wood, C. J. Rizzo, G. T. Furst, P. J. Carroll, J. Donohue, and S. Ômura: Solution and crystal structures of (+)-hitachimycin (stubomycin). J. Org. Chem., 55, 1133-1135 (1990).

436) H. Takeshima, M. Namiki, J. Inokoshi, T. Lee, A. Abe, Y. Suzuki, and S. Ômura: Stable expression of hepatitis $\mathrm{B}$ virus genome in a primate kidney cell. Arch. Virol., 109, 35-49 (1989).

437) S. Funayama, M. Ishibashi, K. Komiyama, and S. Ômura: Biosynthesis of furaquinocins A and B. J. Org. Chem., 55, 1132-1133 (1990).

438) K. Komiyama, S. Funayama, Y. Anraku, M. Ishibashi, Y. Takahashi, and S. Ômura: Novel antibiotics, furaquinocins A and B. Taxonomy, fermentation, isolation and physico-chemical and biological characteristics. J. Antibiot., 43, 247-252 (1990).

439) S. Kakinuma, H. Ikeda, S. Ômura, and D. A. Hopwood: Biosynthesis of kalafungin in Streptomyces tanashiensis J. Antibiot., 43, 391-396 (1990).

440) H. Kumagai, H. Tomoda, and S. Ômura: Method of search for microbial inhibitors of mevalonate biosynthesis using animal cells. J. Antibiot., 43, 397-402 (1990).

441) S. Ômura, Y. Kondo, and Z. Itoh: Motilide, Motilin-like macrolides (Review article). In "Motilin" (Ed. by Z. Itoh) 245-256, Academic Press (1990).

442) Y. Tanaka and S. Ômura: Metabolism and products of actinomycetes-an introduction. Actinomycetol., 4, 13-14 (1990).

443) Y. Takahashi, Y. Seki, Y. Tanaka, R. Oiwa, Y. Iwai, and S. Ômura: Vertical distribution of microorganisms in soils. Actinomycetol., 4, 1-6 (1990).

444) R. Thiericke, A. Zeeck, A. Nakagawa, S. Ômura, R. E. Herrold, S. T. S. Wu, J. M. Beale, and H. G. Floss: Biosynthesis of the manumycin group antibiotics. J. Am. Chem. Soc., 112, 3979-3987 (1990).

445) S. Ômura, Y. Tanaka, I. Kanaya, M. Shinose, and Y. Takahashi: Phthoxazolin, a specific inhibitor of cellulose biosynthesis, produced by a strain of Streptomyces sp. J. Antibiot., 43, 1034-1036 (1990).

446) K. Oshino, H. Kumagai, H. Tomoda, and S. Ômura: Mechanism of action of atpenin B on Raji cells. J. Antibiot., 43, 1064-1068 (1990).

447) A. B. Smith, III, J. L. Wood, W. Wong, A. E. Gould, C. J. Rizzo, S. Funayama, and S. Ômura: (+)-Trienomycins A, B, and C: Relative and absolute stereochemistry. J. Am. Chem. Soc., 112, 7425-7426 (1990).

448) S. Kakinuma, H. Ikeda, H. Tanaka, and S. Ômura: Isolation of restriction-reduced mutants from Streptomyces. Agricult. Biol. Chem., 54, 2611-2617 (1990).

449) H. Tomoda and S. Ômura: New strategy for discovery of enzyme inhibitors: screening with intact mammalian cells or intact microorganisms having special functions (Review article). J. Antibiot., 43, 1207-1222 (1990).

450) H. Mori, S. Funayama, Y. Sudo, K. Komiyama, and S. Ômura: A new antibiotic, 13-hydroxyglucopiericidin A. Isolation, structure elucidation and biological characteristics. J. Antibiot., 43, 1329-1331 (1990).

451) T. Satoh, N. Inatomi, H. Satoh, S. Marui, Z. Itoh, and S. Ômura: EM-523, an erythromycin derivative, and motilin show similar contractile activity in isolated rabbit intestine. $\mathrm{J}$. Pharmacol. Exp. Ther., 254., 940-944 (1990).

452) T. Katagiri, A. Yamaguchi, T. Ikeda, S. Yoshiki, J. M. Wozney, V. Rosen, E. A. Wang, H. Tanaka, S. Ômura, and T. Suda: The non-osteogenic mouse pluripotent cell line, $\mathrm{C} 3 \mathrm{H} 10 \mathrm{~T} 1 / 2$, is induced to differentiate into osteoblastic cells by recombinant human bone morphogenetic protein-2. Biochem. Biophys. Res. Commun., 172, 295-299 (1990).

453) T. Katagiri, T. Lee, H. Takeshima, T. Suda, H. Tanaka, and S. Ômura: Transforming growth factor- $\beta$ modulates proliferation and differentiation of mouse clonal osteoblastic MC3T3-El cells depending on their maturation stages. Bone and Mineral, 11, 285-293 (1990).

454) H. Kumagai, H. Nishida, N. Imamura, H. Tomoda, and S. Ômura: The structures of atpenins A4, A5 and B, new antifungal antibiotics produced by Penicillium sp. J. Antibiot., 43, 1553-1558 (1990).

455) S. Ômura, T. Fujimoto, K. Otoguro, K. Matsuzaki, R. Moriguchi, H. Tanaka, and Y. Sasaki: Lactacystin, a novel microbial metabolite, induces neuritogenesis of neuroblastoma cells. J. Antibiot., 44, 113-116 (1991).

456) S. Ômura, K. Matsuzaki, T. Fujimoto, K. Kosuge, T. Furuya, S. Fujita, and A. Nakagawa: Structure of lactacystin, a new microbial metabolite which induces differentiation of neuroblastoma cells. J. Antibiot., 44, 117-118 (1991).

457) H. Tomoda, H. Nishida, R. Masuma, J. Cao, S. Okuda, and S. Ômura: Purpactins, new inhibitors of acyl-CoA:cholesterol acyltransferase produced by Penicillium 
purpurogenum. I. Production, isolation and physico-chemical and biological properties. J. Antibiot., 44, 136-143 (1991).

458) H. Nishida, H. Tomoda, J. Cao, S. Okuda, and S. Ômura: Purpactins, new inhibitors of acyl-CoA:cholesterol acyltransferase produced by Penicillium purpurogenum. II. Structure elucidation of purpactins A, B and C. J. Antibiot., 44, 144-151 (1991).

459) H. Nishida, H. Tomoda, J. Cao, S. Araki, S. Okuda, and S. Ômura: Purpactins, new inhibitors of acyl-CoA:cholesterol acyltransferase produced by Penicillium purpurogenum. III. Chemical modification of purpactin A. J. Antibiot., 44, 152-159 (1991).

460) H. Tomoda, K. Igarashi, J.-C. Cyong, and S. Ômura: Evidence for an essential role of long chain acyl-CoA synthetase in animal cell proliferation. J. Biol. Chem., 266, 4214-4219 (1991).

461) M. Ishibashi, S. Funayama, Y. Anraku, K. Komiyama, and S. Ômura: Novel antibiotics, furaquinocins C, D, E, F, G and H. J. Antibiot., 44, 390-395 (1991).

462) S. Ômura, H. Ikeda, and H. Tanaka: Selective production of specific components of avermectins in Streptomyces avermitilis. J. Antibiot., 44, 560-563 (1991).

$463)$ A. B. Smith, III, J. L. Wood, and S. Ômura: (+)-Mycotrienins I and II: Relative and absolute stereochemistry. Tetrahedron Lett., 32, 841-842 (1991).

464) A. B. Smith, III, J. L. Wood, A. E. Goud, S. Ômura, and K. Komiyama: Isolation and structure determination of (+)-trienomycin F. An endgame synthetic strategy for the trienomycin family of antitumor antibiotics. Tetrahedron Lett., 32, 1627-1630, (1991).

465) S. Ômura and Y. Tanaka: Strategy and methods in screening of new microbial metabolites for plant protection (Review article). In "Pesticide Chemistry" (Ed. by H. Frehse) 87-96, VCH (1991).

466) H. Ikeda and S. Omura: Genetics of antibiotic-producing Streptomyces. The Kitasato Arch. Exp. Med., 63, 143-155 (1990).

467) K. Tsuzuki, F.-S. Yan, K. Otoguro, and S. Ômura: Synthesis and nematocidal activities of jietacin $A$ and its analogs. J. Antibiot., 44, 774-784 (1991).

468) K. Komiyama, S. Funayama, Y. Anraku, M. Ishibashi, Y. Takahashi, T. Kawakami, and S. Ômura: A new antibiotic, okicenone. I. Taxonomy, fermentation, isolation and biological characteristics. J. Antibiot., 44, 814-818 (1991).

469) S. Funayama, M. Ishibashi, K. Komiyama, and S. Ômura: A new antibiotic, okicenone. II. Physico-chemical properties and structure elucidation. J. Antibiot., 44, 819-823 (1991).

470) S. Kakinuma, Y. Takada, H. Ikeda, H. Tanaka, S. Ômura, and D. A. Hopwood: Cloning of large DNA fragments, which hybridize with actinorhodin biosynthesis genes, from kalafungin and nanaomycin A methyl ester producers and identification of genes for kalafungin biosynthesis of the kalafungin producer. J. Antibiot., 44, 995-1005 (1991).

471) S. Kakinuma, H. Ikeda, and S. Ômura: Genetic studies of the biosynthesis of kalafungin, a benzoisochromanequinone antibiotic. Tetrahedron, 47, 6059-6068 (1991).

472) Y. Takahashi, Y. Iwai, and S. Ômura: Mode of submerged spore formation in Kitasatosporia setae. J. Gen. Appl. Microbiol., 37, 261-266 (1991).

473) K. Otoguro, K. Komiyama, S. Ômura, and C. A. Tyson: An in vitro cytotoxicity assay using rat hepatocytes and MTT and Coomassie blue dye as indicators. Atla, 19, 352-360 (1991).

474) Y. Sasaki, M. Seto, K. Komatsu, and S. Ômura: Staurosporine, a protein kinase inhibitor, attenuates intracellular $\mathrm{Ca}^{2+}$-dependent contractions of strips of rabbit aorta. Eur. J. Pharmacol., 202, 367-372 (1991).

475) Y. Takahashi, Y. Seki, Y. Iwai, and S. Ômura: Taxonomic properties of five Kitasatosporia strains isolated by a new method. Kitasato Arch. Exp. Med., 64, 123-132 (1991).

476) H. Ikeda and S. Ômura: Strategic strain improvement of antibiotic producer (Review article). Actinomycetol., 5, 86-99 (1991).

477) H. Nishida, H. Tomoda, S. Okuda, and S. Ômura: Biosynthesis of purpactin A. J. Org Chem., 57, 1271-1274 (1992).

478) H. Iwase, I. Ishii-Karakasa, K. Hotta, Y. Tanaka, and S. Ômura: Analysis of porcine gastric mucus glycoprotein added to a culture medium of Streptomyces sp. OH-11242 as the only source of carbon. Comp. Biochem. Physiol. 101B, 651-655 (1992).

479) Y. Honma, T. Kasukabe, M. Hozumi, K. Shibata and S. Ômura: Effects of herbimycin A derivatives on growth and differentiation of K562 human leukemic cells. Anticancer Res., 12, 189-192 (1992).

480) H. Kumagai, H. Tomoda, and S. Ômura: Biosynthesis of antibiotic 1233A (F-244) and preparation of $\left[{ }^{14} \mathrm{C}\right] 1233 \mathrm{~A}$. J. Antibiot., 44, 563-567 (1992).

481) P. G. Dormer and A. B. Smith, III, S. Funayama, and S. Ômura: Furaquinocins A-G: relative and absolute stereochemistry. Tetrahedron Lett., 33, 1717-1720 (1992).

482) S. Ômura: The expanded horizon for microbial metabolites (Review article). Gene, 115, 141-149 (1992).

483) T. Sunazuka, K. Tsuzuki, H. Kumagai, H. Tomoda, H. Tanaka, H. Nagashima, $H$. Hashizume, and S. Ômura: Synthesis of 1233A analogs and their inibitory activity against hydroxymethyl-glutaryl Coenzyme A synthetase. J. Antibiot., 45, 1139-1147 (1992).

484) H. Tomoda, X.-H. Huang, H. Nishida, R. Masuma, Y. K. Kim, and S. Ômura: Glisoprenins, a new inhibitor of acyl-CoA: cholesterol acyltransferase produced by Gliocladium sp. FO-1513. I. Production, isolation and physico-chemical and biological properties. J. Antibiot., 45, 1202-1206 (1992). 
485) H. Tomoda, H. Nishida, X.-H. Huang, R. Masuma, Y. K. Kim, and S. Ômura: New cyclodepsipeptides, enniatins $\mathrm{D}, \mathrm{E}$ and $\mathrm{F}$ produced by Fusarium sp. FO-1305. J. Antibiot., 45,1207-1215 (1992).

486) H. Tomoda and S. Ômura: Microbial secondary metabolites affecting lipid metabolism (Review article). In "Proceedings of the 9th Int. Nat. Biotechnol. Sym. and Exposition" (Eds. by M. R. Ladisch and A. Bose) 117-120 (1992).

487) S. Oh-ishi, K. Yamaki, M. Abe, H. Tomoda, and S. Ômura: The acyl-CoA synthetase inhibitor triacsin $C$ enhanced eicosanoid release in leukocytes. Jpn. J. Pharmacol., 59, 417-418 (1992).

488) S. Ômura: Trends in the search for bioactive microbial metabolites (Review article). J. Industrial Microbiol., 10, 135-156 (1992).

489) A. B. Smith, III, J. L. Wood, C. J. Rizzo, G. T. Furst, P. J. Carroll, J. Donohue, and S. Ômura: (+)-Hitachimycin: Stereochemistry and conformational analysis. J. Am. Chem. Soc., 114, 8003-8007 (1992).

490) J. Inokoshi, H. Takeshima, H. Ikeda, and S. Ômura: Cloning and sequencing of the aculeacin A acylase-encoding gene from Actinoplanes utahensis and expression in Streptomyces lividans. Gene, 119, 29-35 (1992).

491) H. Tomoda, X.-H. Huang, J. Cao, H. Nishida, R. Nagao, S. Okuda, H. Tanaka, S. Ômura, H. Arai, and K. Inoue: Inhibition of acyl-CoA: cholesterol acyltransferase activity by cyclodepsipeptide antibiotics. J. Antibiot., 45, 1626-1632 (1992).

492) H. Nishida, X.-H. Huang, H. Tomoda, and S. Ômura: Glisoprenins, new inhibitors of acyl-CoA: cholesterol acyltransferase produced by Gliocladium sp. FO-1513. II. Structure elucidation of glisoprenins A and B. J. Antibiot., 45, 1669-1676 (1992).

493) S. Funayama, S. Nozoe, C. Tronquet, Y. Anraku, K. Komiyama, and S. Ômura: Isolation and structure of a new polyether antibiotic, octacyclomycin. J. Antibiot., 45, 1686-1691 (1992).

494) D. V. Der Pyl, J. Inokoshi, K. Shiomi, H. Yang, H. Takeshima, and S. Ômura: Inhibition of farnesyl-protein transferase by gliotoxin and acetyl-gliotoxin. J. Antibiot., 45, 1802-1805 (1992).

495) Y. Takahashi, H. Egusa, B. Deng, H. Kiyohara, H. Yamada, Y. Iwai, and S. Ômura: Quantitative analysis for madurose and other sugars in a small amount of actinomycete whole cells by gas-liquid chromatography. Actinomycetol., 6, 69-78 (1992).

496) M. Hayashi, Y. Imai, H. Naraba, H. Tomoda, S. Ômura, and S. Oh-ishi: Enhanced production of platelet-activating factor in stimulated rat leukocytes pretreated with triacsin $\mathrm{C}$, a novel acyl-CoA synthase inhibitor. Biochim. Biophys. Res. Commun., 188, 1280-1285 (1992).

497) I. Ishii-Karakasa, H. Iwase, K. Hotta, Y. Tanaka, and S. Ômura: Partial purification and characterization endo- $\alpha-N$-acetylgalactosaminidase from the culture medium of Streptomyces sp. Biochem. J., 288, 475-482 (1992).

498) S. Ômura, D. Van Der Pyl, J. Inokoshi, Y. Takahashi, and H. Takeshima: Pepticinnamins, new farnesyl-protein transferase inhibitors produced by an actinomycete. I. Producing strain, fermentation, isolation and biological activity. J. Antibiot., 46, 222-228 (1993).

499) K. Shiomi, H. Yang, J. Inokoshi, D. Van Der Pyl, A. Nakagawa, H. Takeshima, and S. Ômura: Pepticinnamins, new farnesylprotein transferase inhibitors produced by an actinomycete. II. Structural elucidation of pepticinnamin E. J. Antibiot., 46, 229-234 (1993).

500) N. Tabata, Y. Suzumura, H. Tomoda, R. Masuma, K. Haneda, M. Kishi, Y. Iwai, and S. Ômura: Xanthoquinodins, new anticoccidial agents produced by Humicola sp. Production, isolation and physico-chemical and biological properties. J. Antibiot., 46, 749-755 (1993).

501) N. Tabata, H. Tomoda, Y. Takahashi, K. Haneda, Y. Iwai, H. Boyd Woodruff, and S. Ômura: Diolmycins, new anticoccidial agents produced by Streptomyces sp. I. Production, isolation and physico-chemical and biological properties. J. Antibiot., 46, 756-761 (1993).

502) N. Tabata, T. Sunazuka, H. Tomoda, T. Nagamitsu, Y. Iwai, and S. Ômura: Diolmycins, new anticoccidial agents produced by Streptomyces sp. II. Structure elucidation of diolmycins A1, A2, B1 and B2, and synthesis of diolmycins A1. J. Antibiot., 46, 762-769 (1993).

503) H. Tomoda, H. Kumagai, H. Tanaka, and S. Ômura: Specific binding of $\beta$-lactone 1233A to 3-hydroxy-3-methyl-glutaryl-Coenzyme synthase. J. Antibiot., 46, 872-874 (1993).

504) H. Ikeda, Y. Takada, C.-H. Pang, H. Tanaka, and S. Ômura: Transposon mutagenesis by $\mathrm{Tn} 4560$ and applications with avermectin-producing Streptomyces avermitilis. J. Bacteriol., 175, 2077-2082 (1993).

505) H. Yamada, I. Oya, T. Nagai, T. Matsumoto, H. Kiyohara, and S. Ômura: Screening of a glucosidase II inhibitor from chinese herbs and its application on the quality control of mulberry bark. Shoyakugaku Zasshi, 47, 47-55 (1993).

506) H. Tanaka and S. Ômura: Microbial products affecting receptor (Review article). Bioscience and Industry, 51, 11-17 (1993).

507) T. Sunazuka, T. Nagamitsu, K. Matsuzaki, H. Tanaka, S. Ômura, and A. B. Smith, III: Total synthesis of (+)-lactacystin, the first non-protein neurotrophic factor. J. Am. Chem. Soc., 115, 5302 (1993).

508) S. Ômura, H. Tomoda, Y. K. Kim., and H. Nishida: Pyripyropenes, high potent inhibitors of acyl-CoA cholesterol acyltransferase produced by Aspergillus fumigatus. J. Antibiot., 46, 1168-1169 (1993).

509) T. Sunazuka, N. Tabata, T. Nagamitsu, H. Tomoda, and S. Ômura: Synthesis of diolmycin analogs and their anticoccidial activities. J. Antibiot., 46, 1178-1180 (1993). 
510) T. Sunazuka, T. Nagamitsu, H. Tanaka, and S. Ômura: An efficient asymmetric synthesis of the four stereoisomers of 3-hydroxyleucine. Tetrahedron Lett., 34, 4447-4448 (1993).

511) Y. Tanaka, I. Kanaya, Y. Takahashi, M. Shinose, H. Tanaka, and S. Ômura: Phthoxazolin A, a specific inhibitor of cellulose biosynthesis from microbial origin. I. Discovery, taxonomy of producing microorganism, fermentation, and biological activity. J. Antibiot., 46, 1208-1213 (1993).

512) Y. Tanaka, I. Kanaya, K. Shiomi, H. Tanaka, and S. Ômura: Phthoxazolin A, a specific inhibitor of cellulose biosynthesis from microbial origin. II. Isolation, physico-chemical properties, and structural elucidations. J. Antibiot., 46, 1214-1218 (1993).

513) J. Inokoshi, H. Takeshima, H. Ikeda, and S. Ômura: Efficient production of aculeacin A acylase in recombinant Streptomyces strains. Appl. Microbiol. Biotechnol., 39, 532-536 (1993).

514) H. Takeshima and S. Omura: Farnesyltransferase inhibitors (Review article). Tanpakushitsu, Kakusan, Koso, 38, 1695-1703 (1993).

515) S. Ômura, N. Inatomi, and Z. Itoh: Motilides (Review article). Tanpakushitsu, Kakusan, Koso, 38, 1881-1890 (1993).

516) N. Tabata, H. Tomoda, K. Matsuzaki, and S. Ômura: Structure and biosynthesis of xanthoquinodins, anticoccidial antibiotics. J. Am. Chem. Soc., 115, 8558-8564 (1993).

517) K. Komiyama, S. Takamatsu, Y. Takahashi, M. Shinose, M. Hayashi, H. Tanaka, Y. Iwai, S. Ômura, and G. Imokawa: New inhibitors of melanogenesis, OH-3984 K1 and K2. I. Taxonomy, fermentation, isolation and biological characteristics. J. Antibiot., 46, 1520-1525 (1993).

518) S. Takamatsu, M.-C. Rho, M. Hayashi, K. Komiyama, H. Tanaka, S. Ômura, and G. Imokawa: New inhibitors of melanogenesis, OH-3984 K1 and K2. II. Physico-chemical properties and structural elucidation. J. Antibiot., 46, 1526-1529 (1993).

519) T. Sunazuka, N. Tabata, T. Nagamitsu, H. Tomoda, S. Ômura, and A. B. Smith: Asymmetric synthesis of the anticoccidial antibiotic diolmycin A1. Determination of absolute stereochemistry. Tetrahedron Lett., 34, 6659-6660 (1993).

520) O. Kawamura, T. Sekiguchi, Z. Itoh, and S. Ômura: Effect of erythromycin derivative EM-523L on human interdigestive gastrointestinal tract. Digestive Diseases and Sciences, 38, 1026-1031 (1993).

521) Y. Tanaka and S. Ômura: Agroactive compounds of microbial origin (Review article). Ann. Rev. Microbiol., 47, 57-87 (1993).

522) K. Komiyama, K. Otoguro, T. Segawa, K. Shiomi, H. Yang, Y. Takahashi, M. Hayashi, T. Otani, and S. Ômura: A new antibiotic, cypemycin. Taxonomy, fermentation, isolation and biological characteristics. J. Antibiot., 46, 1666-1671 (1993).
523) H. Nagashima, H. Kumagai, H. Tomoda, and S. Ômura: Inhibition of hepatic cholesterol biosynthesis by a 3-hydroxy-3-methyl-glutaryl Coenzyme A synthase inhibitor, 1233A, in mice (Review article). Life Sciences, 52, 1595-1600 (1993).

524) J. Inokoshi, H. Takeshima, and S. Ômura: Identification of precursor peptide of aculeacin A acylase as a protein with proteolytic activity. FEMS Microbiol. Lett., 114, 305-310 (1993).

525) N. Inatomi, T. Satoh, H. Satoh, Z. Itoh, and S. Ômura: Comparison of the motor-stimulating action of EM-523, an erythromycin derivative, and prostaglandin $\mathrm{F} 2 \mathrm{a}$ in conscious dogs. Jpn. J. Pharmacol., 63, 209-217 (1993).

526) H. Ikeda and S. Ômura: Genetic aspects of the selective production of useful components in the avermectin producer Streptomyces avermitilis. Actinomycetol., 7, 133-144 (1993).

527) N. Tabata, H. Tomoda, R. Masuma, K. Haneda, Y. Iwai, and S. Ômura: Hynapenes A, B and C, new anticoccidial agents produced by Penicillium sp. I. Production, isolation and physico-chemical and biological properties. J. Antibiot., 46, 1849-1853 (1993).

528) N. Tabata, H. Tomoda, Y. Iwai, and S. Ômura: Hynapenes A, B and C, new anticoccidial agents produced by Penicillium sp. II. Structure elucidation. J. Antibiot., 46, 1854-1858 (1993).

529) S. Ômura, H. Tanaka, K. Matsuzaki, H. Ikeda, and R. Masuma: Isochromophilones I and II, novel inhibitors against gp120-CD4 binding from Penicillium sp. J. Antibiot., 46, 1908-1911 (1993).

530) H. Cho, J. M. Beale, C. Graff, U. Mocek, A. Nakagawa, S. Ômura, and H. G. Floss: Studies on the biosynthesis of the antibiotic reductinomycin in Streptomyces xanthochromogenus. J. Am. Chem. Soc., 115, 12296-12304 (1993).

531) K. Matsuzaki, N. Tabata, H. Tomoda, Y. Iwai, H. Tanaka, and S. Ômura: The structure of xanthoquinodin A1, a novel anticoccidial antibiotic having a new xanthone-anthraquinone conjugate system. Tetrahedron Lett., 34, 8251-8254 (1993).

532) R. Masuma, N. Tabata, H. Tomoda, K. Haneda, Y. Iwai, and S. Ômura: Arohynapenes A and $\mathrm{B}$, new anticoccidial agents produced by Penicillium sp. Taxonomy, fermentation, and structure elucidation. J. Antibiot., 47, 46-53 (1994).

533) H. Tomoda and S. Ômura: Triacsins, Inhibitors of fatty acid activating enzyme (Review article). Tanpakushitsu Kakusan Koso, 38, 1929-1937 (1993).

534) H. Tomoda, Y. K. Kim. H. Nishida, R. Masuma, and S. Ômura: Pyripyropenes, novel inhibitors of acyl-CoA: cholesterol acyltransferase produced by Aspergillus fumigatus. I. Production, Isolation, and biological properties. J. Antibiot., 47, 148-153 (1994).

535) Y. K. Kim, H. Tomoda, H. Nishida, T. Sunazuka, R. Obata, and S. Ômura: Pyripyropenes, novel inhibitors of acyl-CoA: cholesterol acyltransferase produced by 
Aspergillus fumigatus. II. Structure elucidation of pyripyropenes A, B, C and D. J. Antibiot., 47, 154-162 (1994).

536) M. J. Bibb, D. H. Sherman, S. Ômura, and D. A. Hopwood: Cloning sequencing and deduced functions of a cluster of Streptomyces genes probably encoding biosynthesis of the polyketide antibiotic frenolicin. Gene, 142, 31-39 (1994).

537) S. Sato, Y. Honma, M. Hozumi, Y. Hayashi, Y. Matsuo, K. Shibata, S. Ômura, K.-I. Hino, S. Tomoyasu, and N. Tsuruoka: Effects of herbimycin A and its derivatives on growth and differentiation of $\mathrm{Ph}$-positive acute lymphoid leukemia cell lines. Leukemia Res., 18, 221-228 (1994).

538) H. Hashizume, H. Ito, K. Yamada, H. Nagashima, M. Kanao, H. Tomoda, T. Sunazuka, H. Kumagai, and S. Ômura: Synthesis and biological activity of new 3-hydroxy-3-methylglutaryl Coenzyme A (HMG-CoA) synthase inhibitors: 2-oxetanones with a side chain mimicking the folded structure of 1233A. Chem. Pharm. Bull., 42, 512-520 (1994).

539) S. Takamatsu, M.-C. Rho, R. Masuma, M. Hayashi, R. Komiyama, H. Tanaka, and S. Ômura: A novel testosterone 5 $\alpha$-reductase inhibitor, 8',9'-dehydro-ascochlorin produced by Verticillium sp. FO-2787. Chem. Pharm. Bull., 42, 953-956 (1994).

540) N. Funato, H. Takayanagi, Y. Konda, Y. Toda, Y. Harigaya, Y. Iwai, and S. Ômura: Absolute configuration of staurosporine by X-ray analysis. Tetrahedron Lett., 35, 1251-1254 (1994).

541) J. Inokoshi, H. Tomoda, H. Hashimoto, A. Watanabe, H. Takeshima, and S. Ômura: Cerulenin-resistant mutants of Saccharomyces cerevisiae with an altered fatty acid synthase gene. Mol. Gen. Genet. 244, 90-96 (1994).

542) H. Tomoda and S. Ômura: Lipid metabolism inhibitors of microbial origin (Review article). The Kitasato Arch., 65, sup. 1-12 (1993).

543) H. Hashizume, H. Ito, N. Kanaya, H. Nagashima, H. Usui, R. Oshima, M. Kanao, H. Tomoda, T. Sunazuka, H. Kumagai, and S. Ômura: Synthesis and biological activity of new 3-hydroxy-3-methylglutaryl-CoA synthase inhibitors: 2-Oxetanones with a meta-substituent on the benzene ring in the side chain. Chem. Pharm. Bull., 42, 1271-1278 (1994).

544) H. Hashizume, H. Ito, N. Kanaya, H. Nagashima, H. Usui, R. Oshima, M. Kanao, H. Tomoda, T. Sunazuka, T. Nagamitsu, H. Kumagai, and S. Ômura: Synthesis and biological activities of new HMG-CoA synthase inhibitors: 2-oxetanones with a side chain containing biphenyl, triphenyl or phenylpyridine. Heterocycles, 38, 1551-1571 (1994).

545) T. Sunazuka, R. Obata, L. Zhuorong, S. Takamatsu, K. Komiyama, S. Ômura, and A. B. Smith, III: Relative and absolute stereochemistry of the melanogenesis inhibitors $\mathrm{OH}-3984 \mathrm{~K} 1$ and K2. Partial synthesis from albocycline. Tetrahedron Lett., 35, 2635-2636 (1994).
546) A. Nakagawa, S. Takahashi, K. Uchida, K. Matsuzaki, S. Ômura, A. Nakamura, N. Kurihara, T. Nakamatsu, Y. Miyake, K. Take, and M. Kainosho: Biosynthesis of lactacystin. Origin of the carbons and stereospecific NMR assignment of the two diastereotopic methyl groups. Tetrahedron Lett., 35, 5009-5012 (1994).

547) C.-H. Pang, M. Shiiyama, H. Ikeda, H. Tanaka, and S. Ômura: Cosmid vector for cloning and analysis of Streptomyces DNA. Actinomycetol. 8, 21-25 (1994).

548) Y. Iwai, Z.-R. Li, and S. Omura: Studies on Indolo[2,3-a]carbazole alkaloids from microorganisms: Staurosporine (Review article). Kagaku to Seibutsu, 32, 463-469 (1994).

549) K. Haneda, M. Shinose, A. Seino, N. Tabata, H. Tomoda, Y. Iwai, and S. Ômura: Cytosaminomycins, new anticoccidial agents produced by Streptomyces sp. KO-8119. I. Taxonomy, production, isolation and physico-chemical and biological properties. J. Antibiot., 47, 774-781 (1994).

550) K. Shiomi, K. Haneda, H. Tomoda, Y. Iwai, and S. Ômura: Cytosaminomycins, new anticoccidial agents produced by Streptomyces sp. KO-8119. II. Structure elucidation of cytosaminomycins A, B, C and D. J. Antibiot., 47, 782-786 (1994).

551) H. Hashizume, H. Ito, T. Morikawa, N. Kanaya, H. Nagashima, H. Usui, H. Tomoda, T. Sunazuka, H. Kumagai, and S. Ômura: Synthesis and biological activity of new 3-hydroxy-3-methylglutaryl-CoA synthase inhibitors: 2-Oxetanones with a side chain mimicking the extended structure of 1233A. Chem. Pharm. Bull., 42, 2097-2107 (1994).

552) H. Yoshida, N. Arai, M. Sugoh, J. Iwabuchi, K. Shiomi, M. Shinose, Y. Tanaka, and S. Ômura: 4-Chlorothreonine, a herbicidal antimetabolite produced by Streptomyces sp. OH-5093. J. Antibiot., 47, 1165-1166 (1994).

553) K. Matsuzaki, H. Ikeda, T. Ogino, A. Matsumoto, H. Boyd Woodruff, H. Tanaka, and S. Ômura: Chloropeptins I and II, novel inhibitors against gp120-CD4 binding from Streptomyces sp. J. Antibiot., 47, 1173-1174 (1994).

554) S. Ômura and H. Tomoda: Microbial metabolites affecting lipid biosynthesis. Pure and Appl. Chem., 66, 2267-2270 (1994). (Proceeding of 19th International Symposium on the Chemistry of Natural Products).

555) S. Ômura and H. Takeshima: Farnesyl-protein transferase inhibitors (Review article). Drugs of the Future, 19, 751-755 (1994).

556) Y. Minami, K. Yoshida, Y. Azuma, A. Urakawa, T. Kawauchi, T. Otani, K. Komiyama, and S. Ômura: Structure of cypemycin, a new peptide antibiotic. Tetrahedron Lett., 35, 8001-8004 (1994).

557) M. Satoh, T. Sakai, I. Sano, K. Fujikura, H. Koyama, K. Ohshima, Z. Itoh, and S. Ômura: EM574, an erythromycin derivative, is a potent motilin receptor agonist in human gastric antrum. J. Pharm. Exp. Thr., 271, 574-579 (1994). 
558) T. Oikawa, H. Ogasawara, H. Sano, K. Shibata, and S. Ômura: Possible functional groups responsible for inhibition of in vivo angiogenesis by herbimycin A. Biol. Pharm. Bull., 17, 1430-1432 (1994).

559) H. Tomoda, H. Nishida, Y. K. Kim, R. Obata, T. Sunazuka, S. Ômura, J. Bordner, M. Guadliana, P. G. Dormer, and A. B. Smith, III: Relative and absolute stereochemistry of pyripyropene A, a potent, bioavailable inhibitor of acyl-CoA:cholesterol acyl-transferase (ACAT). J. Am. Chem. Soc., 116, 12097-12098 (1994).

560) S. Ômura: Macrolide Antibiotics (in Japanese). Ther. Res., 15, Symposium Series No. 414, 56-66 (1994).

561) X.-H. Huang, H. Tomoda, H. Nishida, R. Masuma, and S. Ômura: Terpendoles, novel ACAT inhibitors produced by Albophoma yamanashiensis. I. Production, isolation and biological properties. J. Antibiot., 48, 1-4 (1995).

562) X.-H. Huang, H. Nishida, H. Tomoda, N. Tabata, K. Shiomi, D.-J. Yang, H. Takayanagi, and S. Ômura: Terpendoles, novel ACAT inhibitors produced by Albophoma yamanashiensis. II. Structure elucidation of terpendoles A, B, C and D. J. Antibiot., 48, 5-11 (1995).

$563)$ N. Tabata, H. Tomoda, R. Masuma, Y. Iwai, and S. Ômura: Fudecalone, a new anticoccidial agent produced by Penicillium sp. FO-2030. J. Antibiot., 48, 53-58 (1995).

564) C.-H. Pang, K. Matsuzaki, H. Ikeda, H. Tanaka, and S. Ômura: Production of 6,8a-seco-6,8a-deoxy derivatives of avermectins by a mutant strain of Streptomyces avermitilis. J. Antibiot., 48, 59-66 (1995).

565) N. Tabata, H. Tomoda, Y. Iwai, and S. Ômura: Arohynapene D, a new anticoccidial agent produced by a Penicillium sp. FO-2295. J. Antibiot., 48, 83-84 (1995).

566) C.-H. Pang, K. Matsuzaki, H. Ikeda, H. Tanaka, and S. Ômura: Production of a new methylated 6,8 a-seco-6,8a-deoxy derivatives of the avermectins by a transformant strain of Streptomyces avermitilis. J. Antibiot., 48, 92-94 (1995).

567) H. Ikeda, Y. Takada, C.-H. Pang, K. Matsuzaki, H. Tanaka, and S. Ômura: Direct production of 5-oxo derivatives of avermectins by a recombinant strain of Streptomyces avermitilis. J. Antibiot., 48, 95-97 (1995).

568) T. Kobayashi, R. Masuma, S. Ômura, and K Watanabe: Materials for the fungus flora of Japan (47). Mycoscience, 35, 399-401 (1994).

569) H. Yamada, K. Shiomi, Q. Xu, T. Nagai, M. Shibata, I. Oya, Y. Takahashi, and S. Ômura: New glycosidases inhibitors, panosialins D and wD produced by Streptomyces sp. OH-5186. J. Antibiot., 48, 205-210 (1995).

570) Y. Honma, Y. Matsuo, Y. Hayashi, and S. Ômura: Treatment of Philadelphia-chromosome-positive human leukemia in scid mouse model with herbimycin A, bcr-abl tyrosine kinase activity inhibitor. Int. J. Cancer, 60, 685-688 (1995).
571) M. Katagiri, M. Hayashi, K. Matsuzaki, H. Tanaka, and S. Ômura: The neurito inducer lactacystin arrests cell cycle at both G0/G1 and G2 phases in Neuro 2a cells. J. Antibiot., 48, 344-346 (1995).

572) Y. Takahashi, M. Shinose, Y. Iwai, and S. Ômura: Transfer of staurosporine-producing strain Streptomyces staurosporeus AM-2282 to the genus Saccharothrix as Saccharothrix aerocolonigenes (labeda 1986) subsp. staurosporeus subsp. nov. Actinomycetol., 9, 19-26 (1995).

573) S. Kakinuma, H. Ikeda, Y. Takada, H. Tanaka, D. A. Hopwood and S. Ômura: Production of the new antibiotic tetrahydrokalafungin by transformants of the kalafungin producer Streptomyces tanashiensis. J. Antibiot., 48, 484-487 (1995).

574) H. Tomoda, N. Tabata, D.-J. Yang, H. Takayanagi, H. Nishida, and S. Omura: Pyripyropenes, novel ACAT inhibitors produced by Aspergillus fumigatus. III. Structure elucidation of pyripyropenes $\mathrm{E}$ to $\mathrm{L}$. J. Antibiot., 48, 495-503 (1995).

575) H. Ikeda, C.-H. Pang, H. Endo, T. Ohta, H. Tanaka, and S. Ômura: Construction of a single component producer from the wild type avermectin producer Streptomyces avermitilis. J. Antibiot., 48, 532-534 (1995).

576) S. Ômura, Y. Sasaki, Y. Iwai, and H. Takeshima: Staurosporine, a potentially important gift from a microorganism. J. Antibiot., 48, 535-548 (1995).

577) H. Ikeda and S. Ômura: Control of avermectin biosynthesis in Streptomyces avermitilis for the selective production of a useful component. J. Antibiot., 48, 549-562 (1995).

578) N. Arai, K. Shiomi, H. Tomoda, N. Tabata, D. J. Yang, R. Masuma, T. Kawakubo, and S. Ômura: Isochromophilones III-VI, inhibitors of acyl-CoA:cholesterol acyltransferase produced by Penicillium multicolor FO-3216. J. Antibiot., 48, 696-702 (1995).

579) K. Matsuzaki, H. Ikeda, R. Masuma, H. Tanaka, and S. Ômura: Isochromophilones I and II, novel inhibitors against gp120-CD4 binding produced by Penicillium multicolor FO-2338. I. Screening, taxonomy, fermentation, isolation and biological activity. J. Antibiot., 48, 703-707 (1995).

580) K. Matsuzaki, H. Tanaka, and S. Ômura: Isochromophilones I and II, novel inhibitors against gp120-CD4 binding produced by Penicillium multicolor FO-2338. J. Antibiot., 48, 708-713 (1995).

581) K. Shiomi, N. Arai, M. Shinose, Y. Takahashi, H. Yoshida, J. Iwabuchi, Y. Tanaka, and S. Ômura: New antibiotics phthoxazolines B, C and D produced by Streptomyces sp. KO-7888. J. Antibiot., 48, 714-719 (1995).

582) Y. Tanaka, M. Sugoh, W.Ji, J. Iwabuchi, H. Yoshida, and S. Ômura: Screening method for cellulose biosynthesis inhibitors with herbicidal activity. J. Antibiot., 48, 720-724 (1995).

583) S. Ômura, F. Kuno, K. Otoguro, T. Sunazuka, K. Shiomi, R. Masuma, and Y. Iwai: Arisugacin, a 
novel and selective inhibitor of acetyl-cholinesterase from Penicillium sp. FO-4259. J. Antibiot., 48, 745-746 (1995).

584) T. Nagamitsu, T. Sunazuka, H. Stump, R. Obata, S. Arima, K. Matsuzaki, H. Tanaka, and S. Omura: Structure-activity relationships of lactacystin, the first non-protein neurotrophic factor. J. Antibiot., 48, 747-748 (1995).

585) R. Obata, T. Sunazuka, L. Zhuorong, H. Tomoda, and S. Ômura: Structure-activity relationships of pyripyropenes fungal acyl-CoA: cholesterol acyltransferase inhibitors. J. Antibiot., 48, 749-750 (1995).

586) H. Tomoda, N. Tabata, D.-J. Yang, H. Takayanagi, and S. Ômura: Terpendoles, novel ACAT inhibitors produced by Albophoma yamanashiensis. III. Production, isolation and structure elucidation of new components. J. Antibiot., 48, 793-804 (1995).

587) H. Tomoda, M. Ito, N. Tabata, R. Masuma, Y. Yamaguchi, and S. Ômura: Amidepsines, inhibitors of diacylglycerol acyltransferase produced by Humicola sp. FO-2942. I. Production, isolation and biological properties. J. Antibiot., 48, 937-941 (1995).

588) H. Tomoda, N. Tabata, M. Ito, and S. Ômura: Amidepsines, inhibitors of diacylglycerol acyltransferase produced by Humicola sp. FO-2942. II. Structure elucidation of amidepsines A, B and C. J. Antibiot., 48, 942-947 (1995).

589) S. Takahashi, K. Uchida, A. Nakagawa, Y. Miyake, M. Kainosho, K. Matsuzaki, and S. Ômura: Biosynthesis of lactacystin. J. Antibiot., 48, 1015-1020 (1995).

590) K. Komiyama, S. Takamatsu, Y.-P. Kim, A. Matsumoto, Y. Takahashi, M. Hayashi, H. Boyd Woodruff, and S. Ômura: Louisianins A, B, C and D: Non-steroidal growth inhibitors of testosterone-responsive SC115 cells. I. Taxonomy, fermentation, isolation and biological characteristics. J. Antibiot., 48, 1086-1089 (1995).

591) S. Takamatsu, Y.-P. Kim, M. Hayashi, K. Furuhata, H. Takayanagi, K. Komiyama, H. Boyd Woodruff, and S. Ômura: Louisianins A, $\mathrm{B}, \mathrm{C}$ and $\mathrm{D}$ : Non-steroidal growth inhibitors of testosterone-responsive SC 115 cells. II. Physico-chemical properties and structural elucidation. J. Antibiot., 48, 1090-1094 (1995).

592) H. Tanaka, M. Katagiri, S. Arima, K. Matsuzaki, J. Inokoshi, and S. Ômura: Neuronal differentiation of neuro $2 \mathrm{~A}$ cells by lactacystin and its partial inhibition by the protein phosphatase inhibitors calyculin A and okadaic acid. Biochem. Biophys. Res. Commun., 216, 291-297 (1995).

593) C. L. Ward, S. Ômura, and R. R. Kopito: Degradation of CFTR by the ubiquitin-proteasome pathway. Cell, 83, 121-127 (1995).

594) S. Mori, K. Tanaka, S. Ômura, and Y. Saito: Degradation process of ligand-stimulated platelet-derived growth factor $\beta$-receptor involves ubiquitin-proteasome proteolytic pathway. J. Biol. Chem., 270, 29447-29452
(1995).

595) K. Shiomi, H. Yang, Q. Xu, N. Arai, M. Namiki, M. Hayashi, J. Inokoshi, H. Takeshima, R. Masuma, K. Komiyama, and S. Ômura: Phenopyrrozin, a new radical scavenger produced by Penicillium sp. FO-2047. J. Antibiot., 48, 1413-1418 (1995).

596) R. Obata, T. Sunazuka, H. Tomoda, Y. Harigaya, and S. Ômura: Chemical modification and structure-activity relationships of pyripyropenes; potent, bioavailable inhibitor of acyl-CoA:cholesterol $O$-acyltransferase (ACAT). Bioorg. Med. Chem. Lett., 5, 2683-2688 (1995).

597) M. Hayashi, Y.-P. Kim, H. Hiraoka, M. Natori, S. Takamatsu, T. Kawakubo, R. Masuma, K. Komiyama, and S. Ômura: Macrosphelide, a novel inhibitor of cell-cell adhesion molecule. I. Taxonomy, fermentation, isolation and biological activities. J. Antibiot., 48, 1435-1439 (1995).

598) Y. Tanaka, M. Sugoh, H. Yoshida, N. Arai, K. Shiomi, A. Matsumoto, Y. Takahashi, and S. Ômura: Hydranthomycin, a new agroactive antibiotic produced by Streptomyces sp. K93-5305. J. Antibiot., 48, 1525-1526 (1995).

599) S. J.-Ohmi, T. Kawaguchi, S. Sugiyama, K. Tanaka, S. Ômura, and H. Kikuchi: Lactacystin, a specific inhibitor of the proteasome, induces apoptosis in human monoblast U937 cells. Biochem. Biophys. Res. Commun., 217, 1070-1077 (1995).

600) T. Nagamitsu, T. Sunazuka, R. Obata, H. Tomoda, H. Tanaka, Y. Harigaya, S. Ômura, and A. B. Smith, III: Total synthesis of (+)-pyripyropene, a potent orally bioavailable inhibitor of acyl-CoA:cholesterol acyltransferase. J. Org. Chem., 60, 8126-8127 (1995).

601) Y. Enomoto, K. Shiomi, M. Hayashi, R. Masuma, T. Kawakubo, K. Tomosawa, Y. Iwai, and S. Ômura: Herquline B, a new platelet aggregation inhibitor produced by Penicillium herquei Fg-372. J. Antibiot., 49, 50-53 (1996).

602) S. Takamatsu, Y.-P. Kim, M. Hayashi, H. Hiraoka, M. Natori, K. Komiyama, and S. Ômura: Macrosphelide, a novel inhibitor of cell-cell adhesion molecule. II. Physicochemical properties and structural elucidation. J. Antibiot., 49, 95-98 (1996).

603) Y. Morikawa, S. Hinata, H. Tomoda, T. Goto, M. Nakai, C. Aizawa, H. Tanaka, and S. Ômura: Complete inhibition of human immunodeficiency virus (HIV) gag myristoylation is necessary for inhibition of particle budding. J. Biol. Chem., 271, 2868-2873 (1996).

604) H. Tomoda, T. Tabata, Y. Nakata, H. Nishida, T. Kaneko, R. Obata, T. Sunazuka, and S. Ômura: Biosynthesis of pyripyropene A. J. Org. Chem., 61, 882-886 (1996).

605) K. Shiomi, R. Uchida, J. Inokoshi, H. Tanaka, Y. Iwai, and S. Ômura: Andrastins A-C, new protein farnesyltransferase inhibitors, produced by Penicillium sp. FO-3929. Tetrahedron Lett., 37, 1265-1268 (1996).

606) K. Oda, Y. Ikehara, and S. Ômura: Lactacystin, an inhibitor of the proteasome, blocks the degradation of a mutant precursor of 
glycosylphosphatidyl-inositol-Linked protein in a Pre-Golgi compartment. Biochem. Biophys. Res. Commun., 219, 800-805 (1996).

607) D.-J. Yang, H. Tomoda, N. Tabata, R. Masuma, and S. Ômura: New isochromophilones VII and VIII produced by Penicillium sp. FO-4164. J. Antibiot., 49, 223-229 (1996).

608) N. Tabata, H. Tomoda, Y. Iwai, and S. Ômura: Xanthoquinodin $\mathrm{B}_{3}$, a new anticoccidial agent produced by Humicola sp. FO-888. J. Antibiot., 49, 267-271 (1996).

609) H. Tomoda, N. Tabata, D.-J. Yang, I. Namatame, H. Tanaka, and S. Ômura, T. Kaneko: Pyripyropenes, novel ACAT inhibitors produced by Aspergillus fumigatus IV. J. Antibiot., 49, 292-298 (1996).

610) K. Katagiri, K. K. Yokoyama, T. Hamamoto, S. Ômura, S. Irie, and T. Katagiri: Lyn and Gfr protein-tyrosine kinases prevent apoptosis during retinoic acid-induced granulocytic differentiation of HL-60 cells. J. Biol. Chem., 271, 11557-11562 (1996).

611) S. Ômura and H. Takeshima: Lactacystin: a tool for elucidation of proteasome functions. Tanpakushitsu Kakusan Koso, 41, 327-336 (1996).

612) N. Inatomi, F. Sato, S. Marui, Z. Itoh, and S. Ômura: Vagus-dependent and vagus-independent mechanisms of action of the erythromycin derivative EM 574 and motilin in dogs. Jpn. J. Pharmacol., 71, 29-38 (1996).

613) N. Tanaka, M. Naganuma, M. Fukuda, Y. Wati, K. Komatu, S. Yoshida, K. Komiyama, and S. Ômura: Novel inhibitor of melanogenesis produced by Talaromyces FO-3182. J. Jpn. Cosmetic Sci. Soc., 20, 3-6 (1996).

614) S. Ômura, J. Inokoshi, R. Uchida, K. Shiomi, R. Masuma, T. Kawakubo, H. Tanaka, Y. Iwai, S. Kosemura, and S. Yamamura: Andrastins A-C, new protein farnesyltransferase inhibitors produced by Penicillium sp. FO-3929. I. Producing strain, fermentation, isolation, and biological activities. J. Antibiotics, 49, 414-417 (1996).

615) R. Uchida, K. Shiomi, J. Inokoshi, T. Sunazuka, H. Tanaka, Y. Iwai, H. Takayanagi, and S. Ômura: Andrastins A-C, new protein farnesyltransferase inhibitors produced by Penicillium sp. FO-3929. II. Structure elucidation and biosynthesis. J. Antibiotics, 49, 418-424 (1996)

616) S. Takamatsu, Y.-P. Kim, M. Hayashi, K Komiyama, G. Imokawa, and S. Ômura: A new inhibitor of melanogenesis, albocycline K3, produced by Streptomyces sp. OH-3984. J. Antibiotics, 49, 485-486 (1996).

617) Y. Takahashi, Y. Iwai, and S. Ômura: Physiological regulation of sporulation of Kitasatosporia setae in submerged culture. Actinomycetol. 10, 43-49 (1996)

618) H. Yoshida, K. Kitamura, K. Tanaka, S. Ômura, T. Miyazaki, T. Hachiya, R. Ohno, and T. Naoe: Accelerated degradation of PML-retinoic acid receptor $\alpha$ (PML-RARA) oncoprotein by all-trans-retinoic acid in acute promyelocytic leukemia: possible role of the proteasome pathway. Cancer Res., 56, 2945-2948 (1996).

619) M. Hayashi, Y.-P. Kim, S. Takamatsu, S Preeprame, T. Komiya, R. Masuma, H. Tanaka, K. Komiyama, and S. Ômura: Chlovalicin, a new cytocidal antibiotic produced by Sporothrix sp. FO-4649. I. Taxonomy, fermentation, isolation and biological activities. J. Antibiotics 49, 631-634 (1996)

620) S. Takamatsu, Y.-P. Kim, T. Komiya, T. Sunazuka, M. Hayashi, H. Tanaka, K. Komiyama, and S. Ômura: Chlovalicin, a new cytocidal antibiotic produced by Sporothrix sp. FO-4649. II. Physicochemical properties and structural elucidation. J. Antibiotics 49 , 635-638 (1996).

621) S. Ômura and H. Tomoda: Lactacystin, a specific inhibitor of proteasome: from its discovery to its application (Review article). Cell Technology, 15, 929-940 (1996).

622) A. Nakagawa and S. Ômura: Biosynthesis of bioactive microbial metabolites and its application to the structural studies and production of hybrid compounds (Review article). J. Antibiotics, 49, 717-741 (1996).

623) F. Kuno, K. Otoguro, K. Shiomi, Y. Iwai, and S. Ômura: Arisugacins $\mathrm{A}$ and $\mathrm{B}$, novel and selective acetylcholinesterase inhibitors from Penicillium sp. FO-4259. I. Screening, taxonomy, fermentation, isolation and biological activity. J. Antibiotics, 49, $742-747$ (1996).

624) F. Kuno, K. Shiomi, K. Otoguro, T. Sunazuka, and S. Ômura: Arisugacins A and B, novel and selective acetylcholinesterase inhibitors from Penicillium sp. FO-4259. II. Structure elucidation. J. Antibiotics, 49, 748-751 (1996).

625) Y. Funabashi, Y. Maeshiba, N. Inatomi, S. Tanayama, S. Harada, Z. Itoh, and S. Ômura: Bioactive metabolites of EM574 and EM523, erythromycin derivatives having strong gastrointestinal motor stimulating activity. J. Antibiotics, 49, 794-801 (1996).

626) Y. Funabashi, S. Hakoda, N. Inatomi, K. Koyama, S. Tanida, S. Harada, Z. Itoh, and S. Ômura: Microbial conversion of EM574 and EM523, gastrointestinal motor stimulating agents. J. Antibiotics, 49, 802-810 (1996).

627) Y. Murakami, N. Tanahashi, K. Tanaka, S. Ômura, and S. Hayashi: Proteasome pathway operates for the degradation of ornithine decarboxylase in intact cells. Biochem. J., 317, 77-80 (1996).

628) T. Nagamitsu, T. Sunazuka, H. Tanaka, S. Ômura, P. A. Sprengeler, and A. B. Smith, III: Total synthesis of (+)-lactacystin. J. Am. Chem. Soc., 118, 3584-3590 (1996).

629) S. Ômura and K. Shiomi: Drug discovery and microbial secondary metabolites (Review article). Bioscience and Industry, 54, 633-635 (1996).

630) S. Ômura: Feature of antibiotics in the $21 \mathrm{st}$ century (Review article). Jpn. J. Antibiotics, 49, 755-765 (1996).

631) T. Sunazuka and S. Ômura: Chemistry and synthetic study of lactacystin, the first non-protein neurotrophic factor. J. Syn. 
Org. Chem., Jpn., 54, 740-751 (1996).

632) E. Fujita, T. Mukasa, T. Tsukahara, K. Arahata, S. Ômura, and T. Momoi: Enhancement of CPP32-like activity in the TNF-treated U937 cells by the proteasome inhibitors. Biochem. Biophys. Res. Commun., 224, $74-79$ (1996).

$633)$ R. Uchida, K. Shiomi, T. Sunazuka, J. Inokoshi, A. Nishizawa, T. Hirose, H. Tanaka, Y. Iwai, and S. Ômura: Kurasoins A and B, new protein farnesyltransferase inhibitors produced by Paecilomyces sp. FO-3684. II. Structure elucidation and total synthesis. J. Antibiotics, 49, 886-889 (1996).

634) H. Tomoda, Y. Yamaguchi, N. Tabata, T. Kobayashi, R. Masuma, H. Tanaka, and S. Ômura: Amidepsine E, an inhibitor of diacylglycerol acyltransferase produced by Humicola sp. FO-5969. J. Antibiotics, 49, 929-931 (1996).

635) R. Uchida, K. Shiomi, J. Inokoshi, R. Masuma, T. Kawakubo, H. Tanaka, Y. Iwai, and S. Ômura: Kurasoins $\mathrm{A}$ and $\mathrm{B}$, new protein farnesyltransferase inhibitors produced by Paecilomyces sp. FO-3684. I. Producing strain, fermentation, isolation and biological activities. J. Antibiotics, 49, 932-934 (1996).

636) F. Sztaricskai, Z. Kinya, M. M. Puskas, G. Batta, R. Masuma, and S. Ômura: Semisynthetic modification of antibiotic lincomycin. J. Antibiotics, 49, 941-943 (1996).

637) A. B. Smith, III, T. Kinsho, T. Sunazuka and S. Ômura: Biomimetic total synthesis of the ACAT inhibitor (+)-pyripyropene E. Tetrahedron Lett., 37, 6461-6464 (1996).

638) R. Yamada, K. Fukuda, M. Kawanishi, Y. Ohmori, M. Nasu, M. Seto, Y. Sasaki, T. Sunazuka, L. Zhuorong, N. Funato, M. Iguchi, Y. Harigaya, Y. Iwai, and S. Ômura: Synthesis and activity of staurosporine analogs with a lactone functionality. Bioorganic and Med. Chem. Lett., 6, 1893-1896 (1996).

639) Y. Tanaka, K. Matsuzaki, C.-L. Zhong, H. Yoshida, T. Kawakubo, R. Masuma, H. Tanaka, and S. Omura: Dechlorogeodin and its new dihydro derivatives, fungal metabolites with herbicidal activity. J. Antibiot., 49, 1056-1059 (1996).

640) R. Yamada. M. Seto, Y. Sasaki, T. Sunazuka, Y. Harigaya, Y. Iwai, and S. Ômura: Synthesis and anti-platelet aggregation activity of water-soluble staurosporine derivatives. J. Antibiot., 49, 1070-1072 (1996).

641) T. P. McGee, H. H. Cheng, H. Kumagai, S. Ômura, and R. D. Simoni: Degradation of 3-hydroxy-3-methylglutaryl-CoA reductase in endoplasmic reticulum membranes is accelerated as a result of increase susceptibility to proteolysis. J. Biol. Chem., 271, 25630-25638 (1996).

642) M. V. Blagosklonny, G. S. Wu, S. Ômura, and W. S. El-Diery: Proteasome-dependent regulation of $\mathrm{p} 21 \mathrm{WAF} 1 / \mathrm{CiP} 1$ expression. Biochem. Biophys. Res. Commun., 227, 564-569 (1996).

643) H. Miura, H. Tomoda, K. Miura, K. Takishima, and S. Ômura: Lactacystin increase LDL receptor level on HepG2 cells. Biochem. Biophys. Res. Commun., 227, 684-687 (1996).

644) R. Obata, T. Sunazuka, Z. Li, Z. Tian, Y. Harigaya, N. Tabata, H. Tomoda, and S. Ômura: Chemical modification and structure-activity relationships of pyripyropenes.

Modification at the four hydroxyl groups. J. Antibiot., 49, 1133-1148 (1996).

645) R. Obata, T. Sunazuka, Y. Kato, H. Tomoda, Y. Harigaya, and S. Ômura: Chemical modification and structure-activity relationships of pyripyropenes. II. 1,11-Cyclic analogs. J. Antibiot., 49, 1149-1156 (1996).

646) H. Ikeda and S. Ômura: Production of useful microbial secondary metabolites by engineered biosynthesis (Review article). Kagaku to Seibutsu, 34, 761-771 (1996).

647) M. Hayashi, Y.-P. Kim, S. Takamatsu, A. Enomoto, M. Shinose, Y. Takahashi, H. Tanaka, K. Komiyama, and S. Ômura: Madindoline, a novel inhibitor of IL-6 activity from Streptomyces sp. K93-0711. I. Taxonomy, fermentation, isolation and biological activities. J. Antibiot., 49, 1091-1093 (1996).

648) Y. Takahashi, A. Matsumoto, A. Seino, Y. Iwai, and S. Ômura: Rare actinomycetes isolated from desert soil. Actinomycetol. 10, 91-97 (1996).

649) H. Gouda, K. Matsuzaki, H. Tanaka, S. Ômura, J. A. McCauley, P. A. Sprengeler, G. T. Furst, and A. B. Smith, III: Stereostructure of (-)-chloropeptin I, a novel inhibitor of gp120-CD4 binding, via high-temperature molecular dynamics, Monte Carlo Conformational searching, and NMR spectroscopy. J. Am. Chem. Soc., 118, 13087-13088 (1996).

650) R. Uchida, K. Shiomi, J. Inokoshi, H. Tanaka, Y. Iwai, and S. Ômura: Andrastin D, novel protein farnesyltransferase inhibitor produced by Penicillium sp. FO-3929. J. Antibiot., 49, 1278-1280 (1996).

651) H. Tanaka, K. Matsuzaki, H. Nakashima, T. Ogino, A. Matsumoto, H. Ikeda, H. Boyd Woodruff, and S. Ômura: Chloropeptins, new anti-HIV antibiotics inhibiting gp120-CD4 binding from Streptomyces sp. I. Taxonomy, fermentation, isolation, and physico-chemical properties and biological activities. J. Antibiot. 50, 58-65 (1997).

652) K. Matsuzaki, T. Ogino, T. Sunazuka, H. Tanaka, and S. Ômura: Chloropeptins, new anti-HIV antibiotics inhibiting gp120-CD4 binding from Streptomyces sp. II. Structure elucidation of chloropeptin I. J. Antibiot., 50, 66-69 (1997).

653) M. Jeffers, G. A. Taylor, K. M. Weidner, S. Ômura, and G. V. Woude: Degradation of the Met tyrosine kinase receptor by the ubiquitin-proteasome pathway. Mol. Cell. Biol., 17, 799-808 (1997).

654) R. J. Rayanade, K. Patel, M. Ndubuisit, S. Sharma, S. Ômura, J. D. Etlinger, R. Pine, and P. B. Sehgal: Proteasome- and p53-dependent masking of signal transducer and activator of transcription (STAT) factors. J. Biol. Chem., 
272, 4659-4662 (1997).

655) Y.-P. Kim, S. Takamatsu, M. Hayashi, K. Komiyama, and S. Ômura: Pyridindolols K1 and K2, new alkaloids from Streptomyces sp. K93-0711. J. Antibiot., 50, 189-193 (1997).

656) Y. Tanaka, H. Yoshida, Y. Enomoto, K. Shiomi, M. Shinose, Y. Takahashi, J.-R. Liu, and S. Ômura: Malolactomycins $\mathrm{C}$ and $\mathrm{D}$, new 40-membered macrolides active against Botrytis. J. Antibiot., 50, 194-200 (1997).

657) R. Obata, T. Sunazuka, Z. Tian, H. Tomoda, Y. Harigaya, and S. Ômura: Chemical modification and structure-activity relationships of pyripyropenes. 3. Synthetic conversion of pyridine-pyrone moiety. J. Antibiot., 50, 229-236 (1997).

658) T. Sunazuka, T. Zhi-Ming, Y. Harigaya, S. Takamatsu, M. Hayashi, K. Komiyama, and S. Ômura: Efficient chemical conversion of louisianin $\mathrm{A}$ to $\mathrm{C}$ and $\mathrm{D}$, the inhibitor of angiogenesis. J. Antibiot., 50, 274-275 (1997).

659) S. C. Munday-Finch, A. L. Wilkins, C. O. Miles, H. Tomoda, and S. Ômura: Isolation and structure elucidation of lolilline, a possible biosynthetic precursor of the lolitrem family of tremorgenic mycotoxins. J. Agricult. Food Chem., 45, 199-204 (1997).

660) S. Ômura: Biologically active microbial metabolites. In "Medicinal Chemistry: Today and Tomorrow" (Ed. by M. Yamazaki) 43-48 (1997).

661) H. Tomoda, H. Kumagai, Y. Ogawa, T. Sunazuka, H. Hashizume, H. Nagashima, and S. Omura: Synthesis of four chiral isomers of $\beta$-lactone DU-6622 and inhibition of HMG-CoA synthase by the specific $(2 \mathrm{R}, 3 \mathrm{R})$-isomer. J. Org. Chem., 62, 2161-2165 (1997).

662) F. Sato, M. Sekiguchi, S. Marui, N. Inatomi, A. Shino, Z. Itoh, and S. Ômura: EM-574, an erythromycin derivative, is a motilin receptor agonist in the rabbit. E. J. Pharmacol., 322, 63-71 (1997).

663) T. Sunazuka, T. Hirose, T. Z.-Ming, R. Uchida, K. Shiomi, Y. Harigaya, and S. Ômura: Synthesis and absolute structures of novel protein farnesyltransferase inhibitors, kurasoins A and B. J. Antibiot., 50, 453-455 (1997).

664) H. Tanaka, K. Matsuzaki, and S. Ômura: gp120-CD4 binding inhibitors having anti-HIV activity (Review Article). Nippon Nogeikagaku Kaishi 71, 530-534 (1997).

665) H. Ostrowska, C. Wojcik, S. Ômura, and K. Worowski: Lactacystin, a specific inhibitor of the proteasome, inhibits human platelet lysosomal cathepsin A-like enzyme. Biochem. Biophys. Res. Commun., 234, 729-732 (1997).

666) S.-T. Yee, Y. Okada, K. Ogasawara, S. Ômura, A. Takatsuki, T. Kakiuchi, D. Muno, E. Kominami, and T. Mizuochi: MHC class I presentation of an exogenous polypeptide antigen encoded by the murine AIDS defective virus. Microbiol. Immunol., 41, 563-570 (1997).

667) G. Niedermann, R. Grimm, E. Greier, M. Maurer, C. Realini, C. Gartmann, J. Soll, S.
Ômura, M. C. Rechsteiner, W. Baumeister, and K. Eichmann: Potential immunocompetence of proteolytic fragments produced by proteasomes before evolution of the vertebrate immune system. J. Exp. Med., 185, 209-220 (1997).

668) F. Takeuchi, K. A. Seta, S. Ômura, and R. A. Roth: Insulin degradation by madin-darby canine kidney cells expressing the insulin receptor. Diabetes Res. and Clin. Practice, 37, 81-90 (1997).

669) J.-P. Perchellet, S. W. Newell, J. B. Labesich, E. M. Perchellet, Y. Chen, D. H. Hua, S. L. Kraft, R. J. Basaraba, S. Ômura, and H. Tomoda: Antitumor activity of novel tricyclic pyrone analogs in murine leukemia cells in vitro. Anticancer Res., 17, 2427-2434 (1997).

670) T. Yamazaki, C. Haass, T. C. Saido, S. Ômura, and Y. Ihara: Specific increase in amyloid $\beta$-protein 42 secretion ratio by calpain inhibition. Biochemistry, 36, 8377-8383 (1997).

671) F. Tokunaga, H. Shirotani, K. Hara, D. Kozuki, S. Ômura, and T. Koide: Intracellular degradation of secretion defect-type mutants of anti-thrombin is inhibited by proteasomal inhibitors. FEBS Lett., 412, 65-69 (1997).

672) H. Tanaka and S. Ômura: Screening of novel receptor-activity compounds of microbial origin (Review article). In "Biotechnology" (Eds. by H.-J. Rehm and G. Reed) 7, 107-132, VCH Verlargsgesellschaft mbH (1997).

673) N. Tabata, N. Ito, H. Tomoda, and S. Ômura: Xanthohumols, diacylglycerol acyltransferase inhibitors, from Humulus lupulus. Phytochemistry, 46, 683-687 (1997).

674) K. Matsui, S. Ômura, H. Cui, S. L. Schauer, G. E. Sonenshein, and S.-T. Ju: Proteasome regulation of Fas ligand cytotoxicity. Eur. J. Immunol., 27, 2269-2278 (1997).

$675)$ E. A. Fisher, M. Zhou, D. M. Mitchell, X. Wu, S. Omura, H. Wang, A. L. Goldberg, and H. N. Ginsberg: The degradation of apolipoprotein $\mathrm{B} 100$ is mediated by the ubiquitin-proteasome pathway and involves heat shock protein 70 . J. Biol. Chem., 272, 20427-20434 (1997).

676) H. Cui, K. Matsui, S. Ômura, S. L. Schauer, R. A. Matulka, G. E. Sonenshen, and S.-T. Ju: Proteasome regulation of activation-induced $\mathrm{T}$ cell death. Proc. Natl. Acad. Sci. USA, 94, 7515-7520 (1997).

677) J. Magae, S. Illenye, T. Tejima, Y.-C. Chang, Y. Mitsui, K. Tanaka, S. Ômura, and N. H. Heintz: Transcriptional squelching by ectopic expression of E2F-1 and p53 is alleviated by proteasome inhibitors MG-132 and lactacystin. Oncogene 15, 759-769 (1997).

678) S. Tanaka, K.-I. Nemoto, E. Yamamura, S. Ômura, A. Ichikawa: Degradation of the 74 $\mathrm{kDa}$ form of L-histidine decarboxylase via the ubiquitin-proteasome pathway in a rat basophilic/mast cell line (RBL-2H3). FEBS Lett., 417, 203-207 (1997).

679) F. Sztaricskai, Z. Dinya, G. Batta, R. Masuma, and S. Ômura: Linkomicin antibiotikum kemiai modositasa. Magyar Kemiai Folyoirat., 103, 524-530 (1997). 
680) T. Sunazuka, T. Hirose, Y. Harigaya, S. Takamatsu, M. Hayashi, K. Komiyama, S. Ômura, P. A. Sprengeler, and A. B. Smith, III: Relative and absolute stereochemistries and total synthesis of (+)-macrosphelides A and B, potent, orally bioavailable inhibitor of cell-cell-adhesion. J. Am. Chem. Soc., 119, 10247-10248 (1997).

681) N. Arai, K. Shiomi, S. Takamatsu, K. Komiyama, M. Shinose, Y. Takahashi, Y. Tanaka, Y. Iwai, J.-R. Liu, and S. Ômura: Amphistin, a new melanogenesis inhibitor, produced by an acinomycete. J. Antibiot., 50, 808-814 (1997).

682) F. Sztaricskai, S. Kinya, G. Batta, A. Mocsari, M. Lollosi, Z. Majer, R. Masuma, and S. Ômura: Chemical synthesis and structural study of lincomycin sulfoxides and a sulfone. J. Antibiot., 50, 866-873 (1997).

683) S. Takamatsu, H. Hiraoka, Y.-P. Kim, M. Hayashi, M.Natori, K. Komiyama, and S. Ômura: Macrosphelides $\mathrm{C}$ and $\mathrm{D}$, novel inhibitors of cell adhesion. J. Antibiot., 50, 878-880 (1997).

684) F. Fang, H. Ui, K. Shiomi, R. Masuma, Y. Yamaguchi, C. G. Zhang, X. W. Zhang, Y. Tanaka, and S. Ômura: Two new components of the aspochalasins produced by Aspergillus sp. J. Antibiot., 50, 919-925 (1997).

685) H. Ikeda and S. Ômura: Avermectin biosynthesis (Review article). Chem. Rev., 97, 2591-2609 (1997).

686) K. Otoguro, F. Kuno, and S. Ômura: Arisugacins, selective acetylcholinesterase inhibitors of microbial origin. Pharmacol. Ther., 76, 45-54 (1997).

687) H. Tomoda and S. Ômura: Application of lactacystin studies on proteasome functions (Review article, in Japanese). Tissue Culture Technol., 23, 503-506 (1997).

688) S. Takamatsu, Y.-P. Kim, A. Enomoto, M. Hayashi, H. Tanaka, K. Komiyama, and S. Ômura: Madindolines, novel inhibitors of IL-6 activity from Streptomyces sp. K93-0711. II. Physico-chemical properties and structural elucidation. J. Antibiot., 50, 1069-1072 (1997).

689) R. Obata, T. Sunazuka, Z. Tian, H. Tomoda, Y. Harigaya, S. Ômura, and A. B. Smith, III: New analogs of the pyripyropene family of ACAT inhibitors via $\alpha$-pyrone fragmentation and $\gamma$-acylation/cyclization. Chem. Lett., 935-936 (1997).

690) M.-C. Rho, M. Toyoshima, M. Hayashi, R. Uchida, K. Shiomi, K. Komiyama, and S. Ômura: Enhancement of drug accumulation by andrastin A produced by Penicillium sp. FO-3929 in vincristine-resistant KB cells. J. Antibiot., 51, 68-72 (1998).

691) J. Delic, P. Masdehora, S. Ômura, J-M Cosset, J. Dumont, J-L Binet, and H. Magdelenat: The proteasome inhibitor lactacystin induces apoptosis and sensitizes chemo- and radioresistant human chronic lymphocytic leukemia lymphocytes to TNF- $\alpha$-initiated apoptosis. British J. Cancer, 77, 1103-1107 (1998).
692) L. Monney, I. Otter, R. Olivier, H. L. Ozer, A. L. Haas, S. Ômura, and C. Borner Defects in the ubiquitin pathway induce caspase-independent apoptosis blocked by Bcl-2. J. Biol. Chem., 273, 6121-6131 (1998).

693) H. Ikeda, L-R Wang, T. Ohta, J. Inokoshi, and S. Ômura: Cloning of the gene encoding avermectin $\mathrm{B} \quad 5-O$-methyltransferase in avermectin-producing Streptomyces avermitilis. Gene, 206, 175-180 (1998).

694) Y. Tanaka, K. Shiomi, K. Kamei, M. S.-Hagino, Y. Enomoto, F. Fang, Y. Yamaguchi, R. Masuma, C. G. Zhang, X. W. Zhang, and S. Ômura Antimalarial activity of radicicol, heptelidic acid and other fungal metabolites. J. Antibiot., 51, 153-160 (1998).

694) Y. Tanaka, K. Shiomi, K. Kamei, M. S.-Hagino, Y. Enomoto, F. Fang, Y. Yamaguchi, R. Masuma, C. G. Zhang, X. W. Zhang, and S. Ômura: Antimaralial activity of radicicol, heptelidic acid and other fungal metabolites. J. Antibiot., 51, 153-160 (1998)

695) Y. Tanaka, F. F. Fang, C. G. Zhang, X. W. Zhang, and S. Ômura: Heme-dependent radical generation from antimalarial fungal metabolites, radicicol and heptelidic acid. J. Antibiot., 51, 451-453 (1998)

696) Y. Tanaka, Y. Takahashi, M. Shinose, S. Ômura, I, I.-Karakawa, H. Iwase, and K. Hotta: Screening and fermentation of endo- $\alpha$ $-N$-acetyl-galactosaminidase $\quad \mathrm{S}, \quad \mathrm{a}$ mucin-hydrolyzing enzyme from Streptomyces acting on the GalNAc-O-Ser(Thr) linkage. J. Ferment. Bioeng., 85, 381-387 (1998).

697) T. Oikawa, T. Sasaki, M. Nakamura, M. Shimamura, N. Tanahashi, S. Ômura, and K. Tanaka: The proteasome is involved in angiogenesis. Biochem. Biophys. Res. Comm., 246, 243-248 (1998).

698) M. Fukushi, N. Amizuka, K. Hoshi, H. Ozawa, H. Kumagai, S. Ômura, Y. Misumi, Y. Ikehara, and K. Oda: Intracellular retention and degradation of tissue-nonspecific alkaline phosphatase with a Gly $^{317}$ - Asp substitution associated with lethal hypophosphatasia. Biochem. Biophys. Res. Comm., 246, 613-618 (1998).

699) H. Ikeda and S. Ômura: Combinatorial biosynthesis: Engineered biosynthesis of polyketide compounds. (Review article, in Japanese).

Tannpakushitu Kakusan Koso, 43, 1265-1277 (1998).

700) T. Sunazuka, T. Nagamitsu, and S. Ômura: Synthetic study of $\alpha$-pyrone meroterpenoides, pyripyropens. J. Synthetic Organic Chem. Japan, 56, 478-488 (1998).

701) A. Matsumoto, Y. Takahashi, M. Mochizuki, A. Seino, Y. Iwai, and S. Ômura: Characterization of actinomycetes isolated from fallen leaves. Actinomycetologica, 12, 46-48 (1998).

702) H. Tomoda, N. Tabata, R. Masuma, S.-Y. Si, and S. Omura: Erabulenols, inhibitors of cholesteryl ester transfer protein produced by Penicillium sp. FO-5637. I. Production, isolation and biological properties. J. Antibiot., 51, 618-623 (1998). 
703) N. Tabata, H. Tomoda, and S. Ômura: Erabulenols, inhibitors of cholesteryl ester transfer protein produced by Penicillium sp. FO-5637. II. Structure elucidation of erabulenols A and B. J. Antibiot., 51, 624-628 (1998).

704) C. Salvat, I. Jariel-Encontre, C. Acquaviva, S. Omura, and M. Piechaczyk: Differential directing of c-Fos and c-Jun proteins to the proteasome in serum-stimulated mouse embryo fibroblasts. Oncogene 17, 327-337 (1998).

705) K. Matsuzaki, H. Tahara, J. Inokoshi, H. Tanaka, R. Masuma, and S. Ômura: New brominated and halogen-less derivatives and structure-activity relationship of azaphilones inhibiting gp120-CD4 binding. J. Antibiot., 51, 1004-1011 (1998).

706) T. Tanaka, A. Mizumoto, E. Mochiki, H. Suzuki, Z. Itoh, and S. Ômura: Effects of EM574 and cisapride on gastric contractile and emptying activity in normal and drug-induced gastroparesis in dogs. J. Pharmacol. Exp. Ther., 287, 712-719 (1998).

707) I. Namatame, H. Tomoda, S. Si, Y. Yamaguchi, R.Masuma, and S. Ômura: Beauveriolides, specific inhibitors of lipid droplet formation in mouse macrophage, produced by Beauveria sp. FO-6979. J. Antibiot., 52, 1-6 (1999).

708) I. Namatame, H. Tomoda, N. Tabata. S. Si, and S. Ômura: Structure elucidation of fungal beauveriolide III, a novel inhibitor of lipid droplet formation in mouse macrophages. $\mathrm{J}$. Antibiot., 52, 7-12 (1999).

709) H. Zhang, H. Tomoda, N. Tabata, M. Oohori, M. Shinose, Y. Takahashi, and S. Omura: Zelkovamycin, a new cyclic peptide antibiotic from Streptomyces sp. K96-0670. I. Production, isolation and biological properties. J. Antibiot., 52, 29-33 (1999).

710) N. Tabata, H. Tomoda, H. Zhang, R. Uchida, and S. Ômura: Zelkovamycin, a new cyclic peptide antibiotic from Streptomyces sp. K96-0670. II. Structure elucidation. J. Antibiot., 52, 34-39 (1999).

711) S. Ômura, Y. Enomoto, M. Shinose, Y. Takahashi, Y. Iwai, and K. Shiomi: Isolation and structure of a new antibiotic viridomycin $\mathrm{F}$ produced by Streptomyces sp. K96-0188. J. Antibiot., 52, 61-64 (1999).

712) T. Sunazuka, H. Takizawa, M. Desaki, K. Suzuki, R. Obata, K. Otoguro, and S. Ômura: Effects of erythromycin and its derivatives on interleukin-8 release by human bronchial epithelial cell line BEAS-2B cells. J. Antibiot., 52, 71-74 (1999).

713) H. Kitagawa, E. Tani, H. Ikemoto, I. Ozaki, A. Nakano, and S. Ômura: Proteasome inhibitors induce mitochondria-independent apoptosis in human glioma cells. FEBS Letters 443, 181-186 (1999)

714) H. Tomoda, C. Matsushima, N. Tabata, I. Namatame, H. Tanaka, M. J. Bamberger, H. Arai, M. Fukuzawa, K. Inoue, and S. Ômura: Structure-specific inhibition of cholesteryl ester transfer protein by azaphilones. J. Antibiot., 52, 160-170 (1999).

715) J. Inokoshi, M. Katagiri, S. Arima, H. Tanaka, M. Hayashi, Y.B. Kim, R. Furumai, M. Yoshida, S.
Horinouchi, and S. Ômura: Neuronal differentiation of Neuro 2a cells by inhibitors of cell cycle progression, trichostatin $\mathrm{A}$ and butyrolactone I. Biochem. Biophys. Res. Commun., 256, 372-376 (1999).

716) P. Masdehors, S. Ômura, H. M.-Beral, F. Mentz, J.-M. Cosset, J. Dumont, H. Magdelenat, and J. Delic: Increased sensitivity of CLL-derived lymphocytes to apoptotic death activation by the proteasome-specific inhibitor lactacystin. British J. of Haematology, 105, $752-757$ (1999).

717) R. Uchida, H. Tomoda, Y. Dong, and S. Ômura: Altenusin, a specific neutral sphingomyelinase inhibitor, produced by Penicillium sp. FO-7436. J. Antibiot., 52, 572-574 (1999).

718) S. Ômura, H. Tomoda, N. Tabata, Y. Ohyama, T. Abe, and M. Namikoshi: Roselipins, novel fungal metabolites having a highly methylated fatty acid modified with a mannose and an arabinitol. J. Antibiot., 52, 586-589 (1999).

719) H. Sonoda, K. Omi, K. Hojo, K. Nishida, S. Ômura, and K. Sugita: Suppression of oncogenic transformation by hypothemycin associated with accelerated cyclin D1 degradation through ubiquitin-proteasome pathway. Life Sciences, 65, 381-394 (1999).

720) I. Namatame, H. Tomoda, H. Arai, K. Inoue, and S. Ômura: Complete inhibition of mouse macrophage-derived foam cell formation by triacsin C. J. Biochem., 125, 319-327 (1999).

721) Y. Takahashi, A. Seino, Y. Iwai, and S. Ômura: Taxonomic study and morphological differentiation of an actinomycete genus, Kitasatospora. (Review article). Zent. bl. Bakteriol., 289, 265-284 (1999).

722) H. Ikeda, T. Nonomiya, M. Usami, T. Ohta, and S. Ômura: Organization of the biosynthetic gene cluster for the polyketide anthelmintic macrolide avermectin in Streptomyces avermitilis. Proc. Natl. Acad. Sci., USA, 96, 9509-9514 (1999).

723) T. Tanaka, A. Mizumoto, E. Mochiki, H. Suzuki, Z. Itoh, and S. Ômura: Effect of EM574 on postprandial pancreaticobiliary secretion, gastric motor activity, and emptying in conscious dogs. Digestive Diseases and Sci., 44, 1100-1106 (1999).

724) H. Tomoda, Y. Ohyama, T. Abe, N. Tabata, M. Namikoshi, Y. Yamaguchi, R. Masuma, and S. Ômura: Roselipins, inhibitor of diacylglycerol KF-1040. J. Antibiot., 52, 689-694 (1999).

725) T. Matsumoto, A. Ishiyama, Y. Yamaguchi, R. Masuma, H. Ui, K. Shiomi, H. Yamada, and S. Omura: Novel cyclopentanone derivatives pentenocins $\mathrm{A}$ and $\mathrm{B}$, with interleukin-1 $\beta$ converting enzyme inhibitory activity, produced by Trichoderma hamatum FO-6903. J. Antibiot., 52, 754-757 (1999).

726) K. Shiomi, H. Tomoda, K. Otoguro, and S. Ômura: Meroterpenoids with various biological activities produced by fungi (Review article). Pure Appl. Chem., 71, 1059-1064 (1999).

727) N. Tabata, Y. Ohyama, H. Tomoda, T. Abe, M. Namikoshi, and S. Ômura: Structure elucidation of roselipins, inhibitors of diacylglycerol acyl-transferase produced by Gliocladium roseum KF-1040. J. Antibiot., 52, 
815-826 (1999)

728) H. Tomoda, I. Namatame, S. Si, K. Kawaguchi. R. Masuma, M. Namikoshi, and S. Ômura: Phenochalasins, inhibitors of lipid droplet formation in mouse macro-phages, produced by Phomopsis sp. FT-0211. J. Antibiotics, 52, 851-856 (1999).

729) H. Tomoda, I. Namatame, N. Tabata, K. Kawaguchi, S. Si, and S. Ômura: Structure elucidation of fungal phenochalasins, novel inhibitors of lipid droplet formation in mouse macrophages. J. Antib iot., 52, 857-861 (1999).

730) Y. Tanaka, K. Kamei, K. Otoguro, and S. Ômura: Heme-dependent radical generation: Possible involvement in antimalarial action of non-peroxide microbial metabolites, nanaomycin $A$ and radicicol. J. Antibiotics, 52, 880-888 (1999).

731) N. Tabata, H. Tomoda, Y. Yamaguchi, R. Masuma, M. J. Bamberger, and S. Ômura: Inhibition of cholesteryl ester transfer protein by fungal metabolites, Antibiotics, 52, 1042-1045 (1999).

732) J. Inokoshi, K. Shiomi, R. Masuma, H. Tanaka, and S. Ômura: Funalenone, a novel collagenase inhibitor produced by Aspergillus niger. J. Antibiotics, 52, 1095-1100 (1999).

733) H. Tomoda, N. Tabata, M. Shinose, Y. Takahashi, H. Boyd Woodruff and S. Ômura: Ferroverdins, inhibitors of cholesteryl ester transfer protein produced by Streptomyces sp. WK-5344. I. Production, isolation and biological properties. J. Antibiotics, 52, 1101-1107 (1999).

734) N. Tabata, H. Tomoda, and S. Ômura Ferroverdins, inhibitors of cholesteryl ester transfer protein produced by Streptomyces sp. WK-5344. II. Structure elucidation. J. Antibiotics, 52, 1108-1113 (1999).

735) S.-I. Kumeda, A. Deguchi, M. Toi, S. Ômura, and K. Umezawa: Induction of Gl arrest and selective growth inhibition by lactacystin in human umbilical vein endothelial cells. Anticancer Res., 19, 3961-3968 (1999).

736) S. Ômura: Antiinfective drugs into the $21 \mathrm{st}$ century (Review Article, in Japanese). Japanese J. Bacteriol, 54, 795-813 (1999).

737) H. Tomoda, N. Ohbayashi, H. Kumagai, H. Hashizume, T. Sunazuka, and S. Ômura: Differential inhibition of HMG-CoA synthase and pancreatic lipase by the specific chiral isomers of $\beta$-lactone DU-6622. Biochem. Biophys. Res. Comm., 265, 536-540 (1999).

738) K. Nakatani, T. Murayama, Y. Satoh, K. Furukawa, S. Omura, and Y. Ohizumi: Modulation of actomyosin ATPase by thiotetromycin is mediated through conformational change of actin. Eur. J Pharmacol., 383, 381-386 (1999).

739) N. Mugita, Y. Konda, H. Nakamura, T. Fujiwara, K. Tanaka, S. Ômura, N. Shimbara, M. Ogawa, H. Saya, and M. Naka: The involvement of proteasome in myogenic differentiation of murine myocytes and human rhabdomyosarcoma cells. Int. J. Mol. Med., 3, 127-137 (1999).

740) I. Namatame, H. Tomoda, M. Arai, and S. Ômura: Effect of fungal metabolites cytochalasans on lipid droplet formation in mouse macrophages. J. Antibiot., 53, 19-25 (2000).
741) K. Otoguro, K. Shiomi, Y. Yamaguchi, N. Arai, T. Sunazuka, R. Masuma, Y. Iwai, and S. Ômura: Arisugacins $\mathrm{C}$ and $\mathrm{D}$, novel acetylcholinesterase inhibitors and their related novel metabolites produced by Penicillium sp. FO-4259-11. J. Antibiot., 53, 50-57 (2000).

742) M. Desaki, H. Takizawa, T. Ohtoshi, T. Kasama, K. Kyobayashi, T. Sunazuka, S. Ômura, K. Yamamoto, and K. Ito: Erythromycin suppresses nuclear Factor- $\kappa \mathrm{B}$ and activator protein-1 activation in human bronchial epithelial cells. Biochem. Biophys. Res. Comm., 267, 124-128 (2000).

743) M. Zhao, H. Kiyoi, Y. Yamamoto, M. Ito, M. Towatari, S. Ômura, T. Kitamura, R. Ueda, H. Saito, and T. Naoe In vivo treatment of mutant FLT3-transformed murine leukemia with a tyrosine kinase inhibitor. Leukemia, 14, 374-378 (2000).

744) I. Namatame, H. Tomoda, and S. Ômura Screening for novel inhibitors of macrophage-derived foam cell formation as potential anti-atherosclerotic agents (Review article, in Japanese). Bioscience and Industry, 58, 193-194 (2000).

745) T. Sunazuka, T. Hirose, T. Shirahata, Y. Harigaya, M. Hayashi, K. Komiyama, S. Ômura, and A. B. Smith, III: Total synthesis of $(+)$-madindoline $\mathrm{A}$ and $(-)$-madindoline $\mathrm{B}$, potent, selective inhibitors of interleukin 6 . Determination of the relative and absolute configurations. J. Am. Chem. Soc., 122, 2122-2123 (2000).

746) T. Hirose, T. Sunazuka, T. Z.-Ming, M. Handa, R. Uchida, K. Shiomi, Y. Hariyaga, and S. Ômura: Novel protein farnesyltransferase inhibitors, and absolute structures of kurasoins A and B. Heterocycles, 53, 777-784 (2000).

747) K. Shiomi, N. Arai, Y. Iwai, A. Turberg, H. Kolbl, and S. Ômura: Structure of argifin, a new chitinase inhibitor produced by Gliocladium sp. Tetrahedron Lett., 41, 2141-2143 (2000).

748) R. Obata, T. Sunazuka, Y. Harigaya, M. Hayashi, M-C. Rho,. H. Tomoda, and S. Ômura: Structure-activity relationships study of pyripyropenes: reversal of cancer cell multidrug resistance. J. Antibiot., 53, 422-425 (2000).

749) Z. Li, T. Sunazuka, R. Yamada, Y. Kato, A. Enomoto, M. Hayashi, Y. Harigaya, and $\mathrm{S}$. Ômura: Synthesis and antiangiogenic activity of staurosporine derivatives. J. Antibiot., 53, 426-429 (2000).

750) Y. Ogiso, A. Tomida, S. Lei, S. Ômura, and T. Tsuruo: Proteasome inhibition circumvents solid tumor resistance to topoisomerase II-directed drugs. Cancer Res., 60, 2429-2434 (2000).

751) F. Sako, S. Marui, N. Inatomi, Z. Itoh, and S. Ômura: EM-574, an erythromycin derivative, improves delayed gastric emptying of semi-solid meals in conscious dogs. European J. Pharmacol., 395, 165-172 (2000).

752) P. Masdehors, H. M.-Beral, K. Maloum, S. Ômura, H. Magdelenat, and J. Delic: Deregulation of the ubiquitin system and p53 proteolysis modify the apoptotic response in B-CLL lymphocytes. Blood, 96, 269-274 (2000). 
753) R. Obata, T. Sunazuka, K. Otoguro, H. Tomoda, Y. Harigaya, and S. Ômura: Synthetic conversion of ACAT inhibitor to acetylcholinesterase inhibitor. Bioorg. Med. Chem. Lett., 10, 1315-1316 (2000).

754) S. Ômura, N. Arai, Y. Yamaguchi, R. Masuma, Y. Iwai, M. Namikoshi, A. Turberg, H. Kolbl, and K. Shiomi: Argifin, a new chitinase inhibitor, produced by Gliocladium sp. FTD 0668. I. Taxonomy, fermentation, and biological activities. J. Antibiot., 53, 603-608 (2000).

755) N. Arai, K. Shiomi, Y. Iwai, and S. Ômura: Argifin, a new chitinase inhibitor, produced by Gliocladium sp. FTD-0668. II. Isolation, physico-chemical properties, and structure elucidation. J. Antibiot., 53, 609-614 (2000).

756) H. Ostrowska, C. Wojcik, S. Wilk, S. Omura, L. Kozlowski, T. Stoklosa, K. Worowski, P. Radziwon: Separation of cathepsin A-like enzyme and proteasome: evidence that lactacystin/ $\beta$-lactone is not a specific inhibitor of the proteasome. J. Biochem. Cell Biol., 32, 747-757 (2000)

757) M. F.-Irie, M. Ito, Y. Amaya, N. Amizuka, H. Ozawa, S. Ômura, Y. Ikehara, and K. Oda: Possible interference between tissue-non-specific alkaline phosphatase with an $\mathrm{Arg}^{54} \rightarrow$ Cyc substitution and a counterpart with an $\operatorname{Asp}^{277} \rightarrow$ Ala substitution found in a compound heterozygote associated with severe hypophosphatasia. Biochem. J., 348, 633-642 (2000).

758) F. Tokunaga, S. Takeuchi, S. Ômura, P. Arvan, and T. Koide: Secretion, $\gamma$-carboxylation, and endoplasmic reticulum-associated degradation of chimeras with mutually exchanged Gla domain between human protein $\mathrm{C}$ and prothrombin. Thrombosis Res., 33, 511-521 (2000).

759) N. Arai, K. Shiomi, Y. Yamaguchi, R. Masuma, Y. Iwai, A. Turberg, H. Kolbl, and S. Ômura: Argadin, a new chitinase inhibitor, produced by Clonostachys sp. FO-7314. Chem. Pharm. Bull., 48, 1442-1446 (2000).

760) H. Tomoda and S. Ômura: Lactacystin, a proteasome inhibitor: Discovery and its application in cell biology (Review articlek in Japanese).Yakugaku Zasshi, 120, 935-949 (2000).

761) M.-C. Rho, M. Hayashi, A. Fukami, R. Obata, T. Sunazuka, H. Tomoda, K. Komiyama, and S. Ômura: Reversal of multidrug resistance by 7-O-benzoylpyripyropene A in multidrug-resitant tumor cells. J. Antibiot., 53, 1202-1206 (2000).

762) A Fukami, T. Nakamura, K. Kawaguchi, M.-C. Roh, A. Matsumoto, Y. Takahashi, K. Shiomi, M. Hayashi, K. Komiyama, and S. Ômura; A new antimicrobial antibiotic from Actinoplanes capillaceus sp. K95-5561T. J. Antibiot., 53, 1212-1214 (2000).

763) A. Fukami, T. Nakamura, Y.-P. Kim, K. Shiomi, M. Hayashi, T. Nagai, H. Yamada, K. Komiyama, and S. Ốmura: A new antiinfluenza virus antibiotic, 10-norparvulenone from Microsphaeropsis sp. FO-5050. J. Antibiot., 53, 1215-1218 (2000).

764) M. Oohori, K. Otoguro, T. Sunazuka, K. Suzuki, Y. Iwai, and S. Ômura: Effect of 14-membered ring macrolide compounds on rat leucocyte chemotaxis and the structure-activity relationships. J. Antibiot., 53, 1219-1222 (2000).

765) H. Gouda, T. Sunazuka, S. Ômura, and S. Hirono: Three-dimensional structure-activity relationship analysis between motilin and motilide using conformational analysis and a novel molecular superposing method. Chem. Pharm. Bull., 48, 1835-1837 (2000).

766) S. Ômura, M. Hayashi, and H. Tomoda: Recent progress of the research on novel microbial metabolites (Review article). Pure Appl. Chem., 71, 1673-1681 (1999).

767) A. Matsumoto, Y. Takahashi, T. Kudo, A. Seino, Y. Iwai, and S. Ômura: Actinoplanes capillaceus sp. nov., a new species of the genus Actinoplanes. Antoie van Leewenhock 78, 107-115 (2000).

768) S. Ômura, H. Miyadera, H. Ui, K. Shiomi, Y. Yamaguchi, R. Masuma, T. Nagamitsu, D. Takano, T. Sunazuka, A, Harder, H. Kolbl, M. Namikoshi, H. Sakamoto, and K. Kita: An anthelmintic compound, nafuredin, shows selective inhibition of complex I in helminth mitochondria. Proc. Natl. Acad. Sci., USA, 98, 60-62 (2001).

769) L. Chen, L. Smith, M. A. Accavitti-Loper, S. Ômura, J. B. Smith: Ubiquitylation and destruction of endogenous c-MycS by the proteasome: Are Myc boxes dispensable? Arch. Biochem. and Biophys., 374, 306-312 (2000).

770) L. Smith, L. Chen, M. E. Reyland, T. A. DeVries, R. V. Talanian, S. Ômura, and J. B. Smith: Activation of a typical protein kinase $\mathrm{C} \xi$ by caspase processing and degradation by the ubiquitin-proteasome system. J. Biol. Chem., 275, 40620-40627 (2000).

771) B.Wojcik, M. Bury, T. Stoklosa, A. Giermasz, W. Feleszko, I. Mlynarczuk, E. Pleban, G. Basak, S. Ômura, and M. Jakobisiak: Lovastatin and simvastatin are modulators of the proteasome. J. Biochem. \& Cell Biol., 32, 957-965 (2000).

772) H. Ui, K. Shiomi, Y. Yamaguchi, R. Masuma, T. Nagamitsu, D. Takano, T. Sunazuka, M. Namikoshi, and S. Ômura: Nafuredin, a novel inhibitor of NADH-fumarate reductase, produced by Aspergillus niger FT-0554. J. Antibiot., 54, 234-238 (2001).

773) Y. Enomoto, K. Shiomi, A. Matsumoto, Y. Takahashi, Y. Iwai, A. Harder, H. Kolbl, H. Boyd Woodruff, and S. Ômura: Isolation of a new antibiotic oligomycin $\mathrm{G}$ produced by Streptomyces sp. WK-6150. J. Antibiot., 54, 308-313 (2001).

774) J. Inokoshi, H. Chiba, S. Asanuma, A. Takahashi, S. Ômura, and H. Tanaka: Molecular cloning of actinohivin, a novel anti-HIV protein from an actinomycete, and its expression in Escherichia coli. Biochem. Biophys. Res. Comm., 281, 1261-1265 (2001).

775) H. Chiba, J. Inokoshi, M. Okamoto, S. Asanuma, K. Matsuzaki, M. Iwama, K. Mizumoto, H. Tanaka, M. Oheda, K. Fujita, H. Nakashima, M. Shinose, Y. Takahashi, and S. Ômura: Actinohivin, a novel anti-HIV protein from an actinomycete that inhibits syncytium formation: isolation, characterization, and biological 
activities. Biochem. Biophys. Res. Comm., 282, 5601 (2001).

776) D. Takano, T. Nagamitsu, H. Ui, K. Shiomi, Y. Yamaguchi, R. Masuma, I. Kuwajima, and S. Ômura: Absolute configuration of nafuredin, a new specific NADH-fumarate reductase inhibitor. Tetrahedron Lett., 42, 3017-3020 (2001).

777) M. Handa, T. Sunazuka, K. Nagai, R. Kimura, T. Shirahata, Z.-M. Tian, K. Otoguro, Y. Harigaya, and S. Ômura: Convergent synthesis of arisugacin skeletons and their acetyl-cholinesterase inhibitory activity. J. Antibiot., 54, 382-385 (2001).

778) M. Handa,. Sunazuka, K. Nagai, R. Kimura, K. Otoguro, Y. Harigaya, and S. Ômura: Determination of absolute stereochemistries of arisugacin $F$ and Territrem B, novel acetylcholinestarase inhibitor. J. Antibiot., 54, 386-391 (2001).

779) H. Inazawa, K. Akagawa, M. Ohori, T. Sunazuka, K. Otoguro, and S. Ômura: Action of macrolide antibiotics on human immunocompetent cells. Jap. J. Antibiot., 54, Suppl. A, 139-142 (2001).

780) L. Kozlowski, T. Stoklosa, S. Ômura, C. Wojcik, M. Z. Wojtukiewicz, K. Worowski, H. Ostrowska: Lactacystin inhibits cathepsin A activity in melanoma cell lines. Tumor Biology, 22, 211-215 (2001).

781) M. Arai, H. Tomoda, A. Matsumoto, Y. Takahashi, B. H. Woodruff, N. Ishiguro , S. Kobayashi, and S. Ômura: Deacetylravidomycin $\mathrm{M}$, a new inhibitor of IL-4 signal transduction, produced by Streptomyces sp. WK-6326. I. Taxonomy, fermentation, isolation and biological activities. J. Antibiot., 54, 554-561 (2001).

782) M. Arai, H. Tomoda, N. Tabata, N. Ishiguro, S. Kobayashi, and S. Ômura: Deacetylravidomycin $\mathrm{M}$, a new inhibitor of IL-4 signal transduction, produced by Strepto-myces sp. WK-6326. II. Structure elucidation. J. Antibiot., 54, 562-566 (2001)

$783)$ A.Tournu, A. Obled, M.-P. Roux, M. Ferrara, S. Ômura, and M. Bechet: Glucose regulates protein catabolism in ras-transformed fibroblasts through a lysosomal-dependent proteolytic pathway. Biochem. J., 357, 255-261(2001)

784) K. Takeuchi, S. Shibamoto, K. Nagamine, I. Shigemori, S. Ômura, N. Kitamura, and F. Ito: Signaling pathways leading to transcription and translation cooperatively regulate the trasient increase in expression of $c$-Fos protein. J. Biol. Chem., 276, 26077-26083 (2001).

785) K. Shiomi, H. Ui, and S. Ômura: Nafuredin, a new anthelmintic antibiotic and its target, complex I (Review Article). Bioscience and Industry, 59, 37-38 (2001).

786) H. Tomoda and S. Ômura: Screening for inhibitors of lipid metabolism. In Enzyme Technologies for Pharmaceutical and Biotechnological Applications (Review article). (eds. H. A. Kirst and Wu-Kuang Yeh, M. J. Zmijewski, Jr.), Marcel Dekker, Inc., 343-378 (2001).

787) D. Takano, T. Nagamitsu H. Ui, K. Shiomi, Y. Yamaguchi, R. Masuma, I. Kuwajima, and S. Ômura: Total synthesis of nafuredin, a selective
NADH-fumarate reductase inhibitor. Org. Lett., 3, 2289-2291 (2001).

788) H. Zhang, H. Tomoda, N. Tabata, H. Miura, M. Namikoshi, Y. Yamaguchi, R. Masuma, and S. Ômura: Cladospolide D, a new 12-membered macrolide antibiotic. Produced by Cladosporium sp. FT-0012. J. Antibiot., 54, 635-641 (2001).

789) K. Otoguro, A. Kohana, C. Manabe, A. Ishiyama, H. Ui, K. Shiomi, H. Yamada, and S. Omura: Potent antimalarial activities of polyether antibiotic, X-206. J. Antibiot., 54, 658-663 (2001).

790) H. Ikeda, T. Nonomiya, and S. Ômura: Organization of biosynthetic gene cluster for avermectin in Streptomyces avermitilis: analysis of enzymatic domains in four polyketide synthases. J. Ind. Microbiol. \& Biotechnol., 27, 170-176 (2001).

791) S. Ômura, H. Ikeda, J. Ishikawa, A. Hanamoto, C. Takahashi, M. Shinose, Y. Takahashi,H. Horikawa, H. Nakazawa, T. Osonoe, H. Kikuchi, T. Shiba, Y. Sakaki, and M. Hattori : Genome sequence of an industrial microorganism Streptomyces avermitilis: deducing the ability of producing secondary metabolites. Proc. Natl. Acad. Sci., USA, 98, 12215-12220 (2001).

792) K. Tajima, Y. Takahashi, A. Seino, Y. Iwai, and S. Ômura: Description of two novel species of the genus Kitasatosporia Omura et al. 1982, Kitasatospora cineracea sp. nov. and Kitasatospora niigatensis sp. Nov. Int. J. Syst. and Evol. Microbiol., 51, 1765-1771 (2001).

793) R. Masuma, Y. Yamaguchi, M. Noumi, S. Ômura, and M. Namikoshi: Effect of sea water concentration of hyphal growth and antimicrobial metabolilte production in marine fungi. Mycoscience, 42, 455-459 (2001).

794) H. Chiba, S. Asanuma, M. Okamoto, J. Inokoshi, H. Tanaka, K. Fujita, and S. Ômura: A simple screening system for anti-HIV drugs: syncytium formation assay using T-cell line tropic and macrophage tropic HIV env expressing cell lines-establishment and validation- J. Antibiot., 54, 818-826 (2001).

795) R. Uchida, H. Tomoda, M. Arai, and S. Ômura: Chlorogentisylquinone, a new neutral sphingomyelinase inhibitor, produced by a marine fungus. J. Antibiot., 54, 882-889 (2001).

796) R. Blaise, P. Masdehors. A. Lauge, D. S.-Lyonnet, C. Alapetite, H. Merle-Beral, J.-L. Binet, S. Ômura, H. Magdelenant, L. Sabatier, and J. Delic: Chromosomal DNA and p53 stability, ubiquitin system and apoptosis in B-CLL lymphocytes. Leukemia and Lymphoma, 42, 1173-1180 (2001).

797) T. Sunazuka, M. Handa, K. Nagai, T. Shirahata, Y. Harigaya, K. Otoguro, I. Kuwajima, and S. Ômura: The first total synthesis of $( \pm)$-arisugasin A, a potent, orally bioavailable inhibitor of acetylcholinesterase. Org. Lett., 4, 367-369 (2002).

798) T. Sunazuka, T. Shirahata, K. Yoshida, D. Yamamoto, Y. Harigaya, T. Nagai, H. Kiyohara, H. Yamada, I. Kuwajima, and S. Ômura: Total synthesis of pinellic acid, a potent oral adjuvant for nasal influenza vaccine. Determination of 
the relative and absolute configuration. Tetrahedron Lett., 43, 1265-1268 (2002).

799) T. Hirose, T. Sunazuka, T. Shirahata D. Yamamoto, Y. Harigaya, I. Kuwajima, and S. Ômura: Short total synthesis of (+)-madindolines A and B. Org. Lett., 4, 501-503 (2002).

800) H. Tomoda, T. Okuda, H. Wang, N. Tabata, R. Masuma, Y. Yamaguchi, and S. Ômura: Funicone-related compounds, potentiators of antifungal miconazole activity, produced by Talaromyces flavus FKI-0076. J. Antibiot., 55, 172-180 (2002).

801) A. Fukami, K. Iijima, M. Hayashi, K. Komiyama, and S. Ômura: Macrosphelide B suppressed metastasis through inhibition of adhesion of $\mathrm{sLe}^{\mathrm{x}} / \mathrm{E}$-selectin molecules. Biochem. Biophys. Res. Comm., 291, 1065-1070 (2002).

802) I. Namatame, H. Tomoda, D. Matsuda, N. Tabata, S. Kobayashi, and S. Ômura: K97-0239A and B, new inhibitors of macrophage foam cell formation, produced by Streptomyces sp. K97-0239. Proc. Japan Acad., 78, 45-50 (2002).

803) Y. Tsuchihashi, K. Oishi, H. Yoshimine, S. Suzuki, A. Kumatori, T. Sunazuka, S. Ômura, K. Matsushima, and T. Nagatake: Fourteen-Member macrolides suppress interleukin-8 production but do not promote apoptosis of activated neutrophils. Antimicrob. Agents and Chemother., 46, 1101-1104 (2002).

804) Y. Yamaguchi, R. Masuma, R. Uchida, M. Arai, H. Tomoda, and S. Ômura: Phoma sp. FOM-8108, a producer of gentisylquinones, isolated from sea Sand. Mycoscience, 43, 127-133 (2002).

805) D. R. Houston, K. Shiomi, N. Arai, S. Ômura, M. G. Peter, A. Turberg, B. Synstad, V. G. H. Eijsink, and D. M. F. van Alten: High-resolution structures of a chitinase complexed with natural product cyclopentapeptide inhibitors: Mimicry of carbohydrate substrate. Proc. Natl. Acad. Sci., USA, 99, 9127-9132 (2002).

806) L. Yu, Y. Takahashi, A. Matsumoto, A. Seino, Y. Iwai, and S. Ômura: Application of PCR for selection of Gram-positive bacteria with high DNA $\mathrm{G}+\mathrm{C}$ content among new isolates. Actinomycetologica, , 16, 1-5 (2002).

807) K. Shiomi and S. Ômura: Discovery of new macrolides. In "Macrolide Antibiotics-Chemsitry, Biology, and Practice", ed., S. Omura, Academic Press, pp. 1-56 (2002).

808) T. Sunazuka, S. Omura, S. Iwasaki, and S. Ômura: Chemical modification of macrolides (Review article). In "Macrolide Antibiotics-Chemistry, Biology, and Practice", ed., S. Omura, Academic Press, pp.99-180 (2002).

809) H. Ikeda and S. Omura: Biosynthesis, regulation, and genetics of macrolide production (Review article). In "Macrolide Antibiotics-Chemsitry, Biology, and Practice", ed., S. Ômura, Academic Press, pp. 285-326 (2002).

810) N. Inatomi, F. Sato, Z. Itoh, and S. Omura: Mode of action of macrolides with motilin agonistic activity-motilides (Review article). In "Macrolide Antibiotics-Chemistry, Biology, and Practice", ed., S. Ômura, Academic Press, pp. 501-531 (2002).

811) S. Ômura: Mode of action of avermectin (Review article). In "Macrolide Antibiotics-Chemsitry, Biology, and Practice", ed., S. Omura, Academic Press, pp.571-576 (2002).

812) K. Otoguro, A. Ishiyama, H. Ui, M. Kobayashi, C. Manabe, G. Yan, Y. Takahashi, H. Tanaka, H. Yamada, and S. Omura: In vitro and in vivo antimalarial activities of the monoglycoside polyether antibiotic, K-41 against drug resistant strains of Plasmodia. J. Antibiot., 55, 832-834 (2002).

813) M. Hayashi, M.-C. Rho, A. Enomoto, A. Fukami, Y.-P. Kim, Y. Kikuchi, T. Sunazuka, T. Hirose, K. Komiyama, and S. Ômura:

Suppression of bone resportion by madindoline A, a novel nonpeptide antagonist to gp130. Proc. Natl. Acad. Sci., USA, 99, 14728-14739 (2002).

814) H. Uciro, K.Nagasawa, T. Sawa, J. Hasegawa, T. Kotake, Y.

Sugiura, S. Kobayashi, K. Otoguro, and S. Ômura: Remarkable influence of the aromatic substructure in 9-methoxy-strobilurin derivatives on their antifungal activity. Bioorg. Med. Chem. Lett., 13, 2699-2702 (2002).

815) H. Koga, H. Takanashi, Z. Ito, and S. Ômura: Design, SAR and pharmacology of GM-611, the first acid-stable nonpeptide motilin receptor agonist (Review article). Drugs of the Future, 27, 255-272 (2002).

816) H. Tomoda, I. Namatame, and S. Ômura: Microbial metabolites with inhibitory activity $\mathrm{K}$ Shiomi, K. Hatae, Y. Yamaguchi, R. Masuma, against lipid metabolism (Review article). Proc. Jap. Acad., 78, 217-240 (2002).

817) H. Tomoda, S. Kobayashi, and S. Ômura: New antibiotics miyakamides produced by a fungus. J. Antibiot., 55, 952-961 (2002).

818) H. Tomoda, M. Arai, N. Koyama, H. Matsui, S. Ômura, R. Obata, and Y. C. Lee: Accelerated degradation of mislocalized UDP-glucuronosyltransferase family 1 (UGT1) protein in Gunn rat hepatocytes. Arch. Biochem. Biophys., 405, 163-169 (2002).

819) Y. Emi, S. Ômura, S. Ikushiro, and T. Iyanagi: Purification of Shiga-like toxin 1 by pigeon egg white glycoproteins immobilized on Sepharose gels. Analytical Biochem., 311, 50-56 (2002).

820) I. Namatame, D. Matsuda, H. Tomoda, Y. Yamaguchi, R. Masuma, S. Kobayashi, and S. Omura: Selective production of fungal beauveriolide I or III by fermentation in amino acid-supplemented media. J. Antibiot., 55, 1048-1052 (2002).

821) Y. Takahashi, A. Matsumoto, A. Seino, J. Ueno, Y. Iwai, and S. Ômura: Streptomyces avermectinius sp. nov., an avermectin-producing strain. Int. J. Syst. Evol. Microbiol., 52, 2163-2168 (2002).

822) Tomoda, N. Tabata, Y. Ohyama and S. Ômura: Core structure in roselipins essential for eliciting inhibitory activity against diacylglycerol acyltransferase. J. Antibiot., 56, 
24-29 (2003).

823) H. Miyadera, K. Shiomi, H. Ui, Y. Yamaguchi, R. Masuma, H. Tomoda, H. Miyoshi, A. Osanai, K. Kita, and S. Ômura: Atpenins, potent and specific inhibitors of mitochondrial complex II (succinate-ubiquinone oxidoreductase).

Proc. Natl. Acad. Sci., USA, 100, 473-477 (2003).

824) H. Ikeda and S. Ômura: Studies on microbial Products after the completion of genome sequence of Streptomyces -Diversity of genes involving secondary metabolite biosynthesais(Review article, in Japanese). Pharmacia 38, 829-833 (2002)

825) H. Ikeda, J. Ishikawa, and S. Ômura: The genome sequence of soil bacterium Streptomyces (Review article, in Japanese). Tanpakushitu Kakusan Koso 47, 1845-1850 (2002).

826) H. Ikeda and S. Ômura: Streptomyces (Review article, in Japanese). Kagaku to Seibutsu, 40, 694-700 (2002).

827) T. Shirahata, T. Sunazuka, K. Yoshida, D. Yamamoto, Y. Harigaya,T. Nagai, H. Kiyohara, H. Yamada, I. Kuwajima, and S. Ômura: Total synthesis and adjuvant activity of all stereoisomers of pinellic acid. Bioorg. Med. Chem. Lett., 13, 937-941 (2003).

828) M Handa, H. Ui, D. Yamamoto, S. Monma, Y. Iwai, T. Sunazuka, and S. Ômura: Structure determination of lustromycin, an antibiotic against anaerobic bacteria. Heterocycle, 59, 497-500 (2003).

829) K. Otoguro, H. Ui, A. Ishiyama, N. Aria, M. Kobayashi,Y. Takahashi, R. Masuma, K. Shiomi, $\mathrm{H}$. Yamada, and S. Ômura: In vitro antimalarial activities of the microbial metabolites. J. Antibiot., 56, 322-324 (2003).

830) S. M. Gantt, J. M. Myung, M. R. S. Briones, W. D. Li, E. J. Corey, S. Omura, V. Nussenzweig, and P. Sinnis: Proteasome inhibitors block development of Plasmodium spp. Antimicrob. Agents Chemother., 42, 2731-2738 (1998)

831) A. Fukami, Y. Taniguchi, t. Nakamura, M.-C. Rho, K. Kawaguchi, M. Hayashi, K. Komiyama, and S. Ômura: New members of the macrosphelides from Microsphaeropsis sp. FO-5050IV. J. Antibiot., 52, 501-504 (1999).

832) H. Ikeda, J. Ishikawa, A. Hanamoto, M. Shinose, H. Kikuchi, T. Shiba, Y. Sakaki, M. Hattori, and S. Ômura: Complete genome sequence and comparative analysis of the industrial microorganism Streptomyces avermitilis. Nature Biotechnol., 21, 526-531 (2003).

833) Y.-P. Kim, H. Tomoda, K. Iizima, T. Fukuda, A. Matsumoto, Y. Takahashi, and S. Ômura: Takanawaenses, novel antifunga. Antibiotics produced by Streptomyces sp. K99-5278. I. Taxonomy, fermentation, isolation and biological properties. J. Antibiot., 56, 448-453 (2003).

834) T. Fukuda, Y.-P. Kim, K. Iizima, H. Tomoda, and S. Ômura: Takanawaenes, novel antifungal antibiotics produced by Streptomyces sp. K99-5278. II. Structure elucidation. J. Antibiot., 56, 454-458 (2003).

835) M. Arai, K. Yamamoto, I. Namatame, H. Tomoda, and S. Ômura: New monordens produced by amidepsine-producing fungus Humicola sp. FO-2942. J. Antibiot., 56, 526-632 (2003).

836) K. Yamamoto, H. Hatano, M. Arai, K. Shiomi, H. Tomoda, and S. Ômura: Structure elucidation of new monordens produced by Humicola sp. FO-2942. J. Antibiot., 56, 533-538 (2003).

837) T. Nagamitsu, D. Takano, K. Shiomi, H. Ui, Y. Yamaguchi, r. Masuma, Y. Harigaya, I. Kuwajima, and S. Ômura: Total synthesis of nafuredin- $\gamma$, a $\gamma$-lactone related to nafuredin with selective inhibitory activity against NADH-fumarate reductase. Tetrahedron Lett., 44, 6441-6444 (2003).

838) T. Sunazuka, K. Yoshida, M. Oohori, K. Otoguro, Y. Harigaya, Y. Iwai, K. S. Akagawa, and S. Ômura: Effect of 14-membered macrolide compounds on monocyte to macrophage differentiation. J. Antibiot., 56, 721-724 (2003).

839) K. Otoguro, H. Ui, A. Ishiyama, M. Kobayashi, H. Togashi, Y. Takahashi, R. Masuma, H. Tanaka, H. Tomoda, H. Yamada, and S. Ômura: In vitro and in vivo antimalarial activities of non-glycoside 18-membered macrolide antibiotic, borrelidin, against drug-resistant strains of Plasmodia. J. Antibot., 56, 727-729 (2003).

840) M. Handa, T. Sunazuka, A. Sugawara, Y. Harigaya, K. Otoguro, and S. Ômura: Total synthesis of the AchE inhibitors (+)-arisugacins F and G. J. Antibiot., 56, 730-733 (2003).

841) Y. Takahashi and S. Ômura: Isolation of new actinomycetes strains for the screening of new bioactive compounds (Review article). J. Gen. Appl. Microbiol., 49, 141-154 (2003).

842) Y. Takahashi, S. Katoh, N. Shikura, H. Tomoda, and S. Ômura: Superoxide dismutase produced by soil bacteria increases bacterial colony growth from soil sample. J. Gen. Appl. Microbiol., 49, 263-266 (2003).

843) T. Takahashi, S. Kusaka, T. Doi, T. Sunazuka, and S. Ômura: A combinatorial synthesis of a macrosphelide library utilizing a palladium-catalyzed carbonylation on a polymer support. Angew. Chem. Int. Ed., 42, 5230-5234 (2003).

844) A. Matsumoto, Y. Takahashi, M. Shinose, A. Seino, Y. Iwai, and S. Omura: Int. J. Sys. Evol. Microbiol., 53, 1553-1559 (2003).

$845)$ D. C. Lamb, H. Ikeda, D. R. Nelson, J. Ishikawa, T. Skaug, C. Jackson, S. Ômura, M. R. Waterman, and S. L. Kelly: Cytochrome P450 complement (CYPome) of the avermectin-producer Streptomyces avermitilis and comparison to that of Streptomyces coelicolor A3(2). Biochem. Biophys. Res. Comm., 307, 610-619 (2003).

846) Y. Sakano, M. Shibuya, A. Matsumoto, Y. Takahashi, H. Tomoda, S. Ômura, and Y. Ebizuka: Lanopylins, A1, B1, A2 and B2, novel lanosterol synthase inhibitors from Streptomyces sp. K99-5041. J. Antibiot., 56, 817-826 (2003).

847) K. Nagai, T. Sunazuka, K. Shiomi, A. Harder, A. Turberg, and S. Ômura: Synthesis and biological activities of novel 4"-alkylidene avermectin derivatives. Bioorg. \& Med. Chem. Lett., 13, 3943-3946 (2003). 
848) K. Kumamoto, T. Ishikawa, and S. Ômura: Chemistry of structurally confused kinamysins (Review article in Japanese). J. Synthetic Organic Chem. Japan, 62, 49-58 (2004).

849) D. Matsuda, I. Namatame, H. Tomoda, S. Kobayashi, R. Zocher, H. Kleinkauf, and S. Ômura: New beauveriolides produced by amino acid-supplemented ffermentation of Beauveria sp. FO-6979. J. Antibiot., 57, 1-9 (2004).

850) I. Namatame, H. Tomoda, S. Ishibashi, and S. Ômura: Antiatherogenic activity of fungal beauveriolides, inhibitors of lipid droplet accumulation in macrophages. Proc. Natl. Acad. Sci., USA, 101, 737-742 (2004)

851) T. Fukuda, M. Arai, Y. Yamaguchi, R. Masuma,H. Tomoda, and S. Ômura: New beauvericins, potentiators of antifungal miconazole activity, produced by Beauveria $\mathrm{sp}$. FKI-1366. I. Taxonomy, fermentation, isolation and biological properties. J. Antibiot., 57, 110-116 (2004)

852) T. Fukuda, M. Arai, H. Tomoda, and S. Ômura: New beauvericins, potentiators of antifungal miconazole activity, produced by Beauveria sp. FKI-1366. II. Structure elucidation. J. Antibiot., 57, 117-124 (2004).

853) S. Iwasaki and S. Ômura: Cell-based screening strategy in the serch for bioactive microbial secondary metabolites (Review article). Proc. Japan Acad. Ser. B, 80, 54-73 (2004).

854) K. Nagai, T. Sunazuka, and S. Ômura: Synthesis of 4"-alkoxy avermectin derivatives using rhodium carbenoid mediated $\mathrm{O}-\mathrm{H}$ insertion reaction. Tetrahedron lett., 45 , 2507-2509 (2004).

855) Y. Yamaguchi, R. Masuma, Y.-P. Kim, R. Uchida, H. Tomoda, and S. Ômura: Taxonomy and secondary metabolites Pseudobotrytis sp. FKA-25. Mycoscience, 45, 9-16 (2004).

856) S. Nunome, A. Ishiyama, M. Kobayashi, K. Otoguro, H. Kiyohara, H. Yamada, and S. Ômura: In vitro antimalarial activity of biflavonoids from Wikstroemia indica. Planta Med., 70, 77-79 (2004).

857) H. Chiba, J. Inokoshi, H. Nakshima, S. Ômura, and H. Tanaka: Actinohivin, a novel anti-human immunodeficiency virus protein from an actinomycete, inhibits viral entry to cells by binding high-mannose type sugar chains of gp120. Biocem. Biophys. Res. Commun., 316, 203-210 (2004).

858) H. Tomoda, N. Ohbayashi, Y. Morikawa, H. Kumagai, and S. Ômura: Binding site for fungal $\beta$-lactone hymeglucin on cytosolic 3-hydroxy-3-methylglutaryl coenzyme A synthase. Biochem. Biophys. Acta, 1636, 22-28 (2004)

859) A. T. Lada, M. Davis, C. Kent, J. Chapman, H. Tomoda, S. Ômura, and L.L. Rudel: identification of ACAT1- and ACAT2-specific inhibitors using a novel, cell-based fluorescence assay: individual ACAT uniqueness. J. Lipid Res., 45, 378-386 (2004).

860) Xu Ping, Y. Takahashi, A. Seino, Y. Iwai, and S. Ômura: Streptomyces scabrisporus sp. nov.
Int. J. Syst. And Evol. Microbiol., 54, 577-581 (2004).

861) T. Nagamitsu, D. Takano, T. Fukuda, K. Otoguro, I. Kuwajima, Y. Harigaya, and S. Ômura: Total synthesis of (-)-borrelidin. Organic Lett., 6, 1865-1867 (2004).

862) M. Desaki, H. Okazaki, T. Sunazuka, S. Ômura, K. Yamamoto, and H. Takizawa: Molecular mechanisms of anti-inflammatory action of erythromycin in human bronchial epithelial cells: possible role in he signaling pathway that regulates nuclear factor- $\kappa \mathrm{B}$ activation. Antimicrob. Agents and Chemother., 48, 1581-1582 (2004).

863) P. Khaomek, H. Kiyohara, K. Otoguro, H. Yamada, and S. Ômura: Chemical constituents of Erythrina suberosa. Nature Medicine, 58, 84 (2004).

864) M. Arai, H. Sato, H. Kobayashi, M. Suganuma, T. Kawabe, H. Tomoda, and S. Ômura: Selective inhibition of bleomycin-induced G2 cell cycle checkpoint by simaomicin $\alpha$. Biochem. Biophys. Res. Comm., 317, 817-822 (2004).

865) N. Arai, M. Chikaraishi, M. Ikawa, S. Omura, and I. Kuwajima: Enantioselective preparation of asymmetrically protected 2-propanoyl-1,3-propanediol derivatives. Tetrahedron Asymmetry, 13, 733-741 (2004).

866) K. Otoguro, A. Ishiyama, M. Kobayashi, H. Sekiguchi, T. Izuhara, T. Sunazuka, H. Tomoda, and S. Omura: In vitro and in vivo antimalarial activities of a carbohydrate antibiotic, prumycin, against drug-resistant strains of Plasmodia. J. Antibiot., 57, 400-402 (2004).

867) Y. Koizumi, M. Arai, H. Tomoda, and S Ômura: Fungerin. A fungal alkaloid, arrests the cell cycle in $M$ phase by inhibition of microtubule polymerization. J. Antibiot., 57, 415-420 (2004)

868) K. Shiomi and S. Ômura: Antiparasitic agents produced by microorganisms. (Review article) Proc. Japan Acad. Ser. B., 40, 245-258 (2004).

869) T. Sunazuka, M. Handa, K. Nagai, T. Shirahata, Y. Harigaya, K. Otoguro, I. Kuwajima, and S. Ômura: Absolute stereochemistries and total synthesis of $(+)$-arisugacins $\mathrm{A}$ and $\mathrm{B}$, potent orally bioactive and selective inhibitors of acetylcholinesterase. Tetrahedron, 60, 7845-7859 (2004).

870) K. Nagai, K. Shiomi, T. Sunazuka, A. Harder, A. Turberg, and S. Ômura: Synthesis and biological evaluation of novel 4"-alkoxy avermectin derivatives. Bioorg. Med. Chem. Lett., 14, 4135-4139 (2004).

871) Y. Koizumi, M. Arai, H. Tomoda, and S. Ômura: Oxaline, a fungal alkaloid, arrests the cell cycle in $M$ phase by inhibition of tubulin polymerization. Biochim. Biophys. Acta, 1693, 47-55 (2004).

872) S. Herai, Y. Hashimoto, H. Higashibata, H Maseda, H. Ikeeda, S. Ômura, and M. Kobayashi: Hyper-inducible expression system for streptomycetes. Proc. Natl. Acad. Sci., USA., 101, 14031-14035 (2004)

873)Y. Sakano, M. Shibuya, Y. Yamaguchi, R. Masuma, H. Tomoda, S. Ômura, and Y. Ebizuka: Epohelmins A and B, novel lanosterol Synthase inhibitors from a fungal strain 
FKI-0929. J. Antibiot. 57, 564-568 (2004).

874) M. Arai, Y. Koizumi, H. Sato, T. Kawabe, M. Suganuma, H. Kobayashi, H. tomoda, and S. Ômura: Boromycin abrogates bleomycininduced G2 checkpoint. J. Antibiot., 57, 662-668 (2004)

$875)$ I. Ghosh, Y. Kishi, H. Tomoda, and S. Ômura: Use of chiral praseodymium shift reagent in predicting the complete stereostructure of glisoprenin A. Organic Lett., 6, 4719-4711 (2004).

876) S. Ômura and A. Crump: The life and times of ivermectin-a success story (Review article). Nature Rev. Microb., 2, 984-989 (2004).

877) K. Shiomi, H. Ui, H. Suzuki, H. Hatano, T. Nagamitsu, D. Takano, H. Miyadera, T. Yamashita, K. Kitao, H. Miyoshi, A. Harder, H. Tomoda, and S. Omura: A $\gamma$-lactone form nafuredin, nafuredin- $\gamma$, also inhibits helminth complex I. J. Antibiot., 58, 50-52 (2005).

878) K. Shiomo, R. Matsui, M. Isozaki, H. Chiba, T. Sugai Y. Yamaguchi, R. Masuma, H. Tomoda, T. Chiba, H. Yan, Y. Kitamura, W. Sugiura, S. Ômura, and H. Tanaka: Fungal phenalenones inhibit HIV-1 integrase. J. Antibiot., 58, 65-68 (2005).

879) K. Shiomi, K. Hatae, H. Hatano, A. Matsumoto, Y. Takahashi, C.-L. Jiang, H. Tomoda, S. Kobayashi, H. Tanaka, and S. Ômura. A new antibitic, antimycin A9, produced by Streptomyces K01-003.

J. Antibiot., 58, 74-78 (2005).

880) K. Yoshida, T. Sunazuka, K. Nagai, A. Sugawara, A. Cho, T. Nagamitsu, Y. Harigaya, K. Otoguro, K. S. Akagawa, and S. Omura. Macrolides with promotive activity of monocyte to macrophage differentiation. J. Antibiot., 58, 79-81 (2005).

881) T. Sunazuka, T. Shirahata, S. Tsuchiya, T. Hirose, R. Mori, Y. Harigaya, I. Kuwajima, and S. Omura: A concise stereoselective route to the indoline spiroaminal framework of neoxaline and oxaline. Org. Lett., 7, 941-943 (2005).

882) T. Sunazuka, K. Yoshida, N. Kojima, T. Shirahata, T. Hirose, M. Handa, D. Yamamoto, Y. Harigaya, I. Kuwajima, and S. Ômura: Total synthesis of (-)-physovenine from (-)-3a-hydroxyfuroindoline. Tetrahedron Lett., 46, 1459-1461 (1005).

883) A. Takahashi, J. Inokoshi, H. Chiba, S. Ômura, and H. Tanaka: Essential regions for antiviral activities of actinohivin, a sugar-binding antihuman immunodeficiency virus protein from an actinomycete. Arch. Biochem. Biophys., 437, 233-240 (2005).

884) T. Fukuda, A. Matsumoto, Y. Takahashi, H. Tomoda, and S. Omura: Phenatic acids A and $\mathrm{B}$, new potentiators of antifungal miconazoole activity produced by Streptomyces sp. K03-0132. J. Antibiot., 58, 252-259 (2005).

$885)$ T. Sunazuka, P. A. Sprengeler, A. B. Smith, III, and S. Omura: Absolute stereochemistries and total synthesis of $(+/)(-)$-macrosphelides, potent, orally bioavailable inhibitors of cell-cell adhesion. Tetrahedron, 61, 3789-3803 (2005).

886) T. Fukuda, Y. Yamaguchi, R. Masuma, H. Tomoda, and S. Ômura: Citridones, new potentiators of antifungal miconazole activity, produced by Penicillium sp. FKI-1938. I. Taxonomy, fermentation, isolation and biological properties. J. Antibiot., 58, 309-314 (2005).

887) T. Fukuda, H. Tomoda, and S. Ômura: Citridones, new potentiators of antifungal miconazole activity, produced by Penicillium sp. FKI-1938. II. Struccture elucidation. J. Antibiot., 58, 315-321 (2005).

888) N. Koyama, T. Nagahiro, Y. Yamaguchi, T. Ohshiro, R. Masuma, H. Tomoda, and S. Ômura: Spylidone, a novel inhibitor of lipid droplet accumulation in mouse mcrophages produced by Phoma sp. FKI-1840. J. Antibiot., 58, 339-345 (2005).

889) R. Uchida, R. Imasato, Y. Yamaguchi, R. Masuma, K. Shiomi, H. Tomoda, and S. Omura: New sesquicillins, insecticidal antibiotics produced by Albophoma sp. FKI-1778. J. Antibiot., 58, 339-345 (2005).

890) T. Hirose, T. Sunazuka, D. Yamamoto, N. Kojima, T. Shirahata, Y. Harigaya, I. Kuwajima, and S. Ômura: Determination of the absolute stereochemistry and asymmetric total synthesis of madindolines $\mathrm{A}$ and $\mathrm{B}$ : a practical improvement to a second-generation approach from the first-generation. Tetrahedron, 61, 6015-6039 (2005).

891) F. V. Rao, D. R. Houston, R. G. Boot, J. M. Aerts, M. Hodkinson, J. Adams, K. Shiomi, S. Ômura, and D. M. F. van Aalten: Specificity and affinity of natural products cyclopentapeptide inhibitors against A. fumigatus, human and bacterial chitinases. Chem. \& Biol., 12, 65-76 (2005).

892) H. Matsui, M. Eguchi, K. Ohsumi, A. Nakamura, Y. Isshiki, K. Sekiya, Y. Kikuchi, T. Nagamitsu, R. Masuma, T. Sunazuka, and S. Ômura: Azhithromycin inhibits the formation of flagellar filaments without suppressing flagelin synthesis of salmonella enterica serovar typhimurium. Antimicrob. Agents and Chemother., 49, 3396-3403 (2005).

893) H. Ui, S. Asanuma, H. Chiba, A. Takahashi, Y. Yamaguchi, R. Masuma, S. Omura, and $\mathrm{H}$. Tanaka: Mycophenolic acid inhibits syncytium formation accompanied by reduction of gp120 expression. J. Antibiot., 58, 514-518 (2005).

894) M. Shibuya, B. B. Snider, Y. Sakano, H. Tomoda, S. Ômura, and Y. Ebizuka: Revised structures of Epohelmins A and B isolated as lanosterol synthase inhibitors from a fungal strain FKI-0929. J. Antibiot., 58, 590-601 (2005).

895) T. Sunazuka, T. Hirose, and S. Ômura: Total synthesis of madindolines, potent selective inhibitors 6, novel bioactive microbial metabolites. J. Synth. Org. Chem., Japan, 63, 1090-1101 (2005)

896) A. Kageyama, Y. Takahashi, T. Seki, H. Tomoda, and S. Ômura: Oryzihumus leprocrescens gen nov., sp. nov. J. Syst. Evol. Microbiol., 55, 2555-2559 (2005).

897) T. Nagamitsu, Y. Harigaya, and S. Ômura: Total synthesis of borrelidin (Review article). Proc. Japan Acad., 81, 244-256 (2005).

898) N. Koyama, T. Nagahiro, Y. Yamaguchi, R. Masuma, H. Tomoda, and S. Ômura. 
Stemphones, novel potentiators of imipenem activity against mechicillin-resistant Staphylococcus aureus, produced by Aspergillus sp. FKI-2136. J. Antibiot., 58, 695-703 (2005).

899) R. Uchida, R. Imasato, K. Shiomi, H. Tomoda, and S. Ômura: Yaequinones $\mathrm{J} 1$ and $\mathrm{J} 2$, novel insecticidal antibiotics from Penicillium sp. FKI-2140. Org. Lett., 7, 5701-5704 (2005).

900) H. Gouda, T. Sunazuka, H. Ui, M. Handa, Y. Sakoh, Y. Iwai, S. Hirono, and S. Ômura: Stereostructure of luminamicin, an anaerobic antibiotic, via molecular dynamics NMR spectroscopy, and the modified Mosher method. Proc. Natl. Acad. Sci., 102, 18286-18291 (2005).

901) T. Sunazuka and S. Ômura: Total synthesis of $\alpha$-pyrone meroterpenoids, novel bioactive microbial metabolites. Chem. Rev., 105, 4559-4580 (2005).

902) R. Uchida, R. Imasato, Y. Yamaguchi, R. Masuma, K.Shiomi, H. Tomoda, and S. Ômura: New insecticial antibiotics, hydroxyfungerins $\mathrm{A}$ and $\mathrm{B}$, produced by Metahizium sp. FKI-1079. J. Antibiot., 58, 804-809 (2005).

903) Y. Yamaguchi, R. Masuma, H. Tomoda, and S. Ômura: A new species of Dinemasporium from sugar cane on Irabujima island, Japan. Mycoscience, 46, 367-369 (2005).

904) K. Nagai, T. doi, t. Sekiguchi, I. Namatame, T. Sunazzuka, H. Tomoda, S. Omura, and T. Takahashi: Synthesis and biological evaluation of a beauveriolide analogue library. J. Combinatorial Chem., 8, 103-109 (2006).

905) J. Matsuo, T. Shirahata, and S. Omura: catalytic and stereoselctive glycosylation with glycosyl N-trichloro-acetylcarbamate. Tetrahedron Lett., 47, 267-271 (2006).

906) R. Uchida, Y.-P. Kim, I. Namatame, H. Tomoda, and S. Ômura: Sespendole, a new inhibitor of lipid droplet synthesis in macrophages, produced by Pseudobotrytis terrestris FKA-25. J. Antibiot., 59, 93-97 (2006).

907) Y. Takahashi, A. Matsumoto, K. Morisaki, and S. Ômura: Patulibacer minatonensis gen. nov., sp. nov., a novel actinobacterium isolated using an agar medium supplemented with superoxide dismutase, and proposal of Patulibacteracea fam. nov. Int. J. Syst. Evol. Microbol., 56, 401-406 (2006).

908) H. Gouda, T. Sunazuka, K. Yoshida, A. Sugawara, Y. Sakoh, S. Omura, and S. Hirono: Three-dimensional solution of monocyte-to-macrophage differentiation. Bioorg. Med. Chem. Lett., 16, 2406-2409 (2006).

909) D. Yamamoto, T. Sunazuka, T. Hirose, N. Kojima, E. Kaji, and S. Ômura: Design, synthesis, and biological activities of madindoline analogues. Bioorg. Med. Chem. Lett., 26, 2807-2811 (2006).

910) R. Horsefield, V. Yankovskaya, G. Sexton, W. whittingham, K. Shiomi, S. Ômura, B. Byrne, G. Cecchini, and S. Iwata: Structural and computational analysis off the quinone-binding site of Complex II (Succinate-ubiquinone oxidoreductase). A mechanism of electron stransfer and proton conduction during ubiquinone reduction. J. Biol. Chem., 281, 7309-7316 (2006).

911) R. Uchida, H. Tomoda, and S. Ômura: Biosynthesis of sespendole. J. Antibiot., 59, 298-302 (2006).

912) M. Iwatsuki, H. Tomoda, R. Uchida, H. Gouda, S. Hirono, and S. Ômura: Lariatins, antimycobacterial peptides produced by Rhodococcus sp. K01-B0171, have a lasso structure. J. Am. Chem. Soc., 128, 7486-7491 (2006). 